\title{
DAS LAMENTAÇÕES ÀS REALIZAÇÕES POSSÍVEIS: UM ESTUDO DE CASO COM PROFESSORES DE INGLÊS DA REDE PÚBLICA DE SÃO PAULO
}

Tese apresentada à Faculdade de Educação da Universidade de São Paulo, para obtenção do título de Doutor em Educação.

Área de Concentração: Linguagem e Educação

Orientadora: Prof ${ }^{a}$. Dra. Gláucia D’Olim Marote Ferro

São Paulo 
AUTORIZO A REPRODUÇÃO E DIVULGAÇÃO TOTAL OU PARCIAL DESTE TRABALHO, POR QUALQUERR MEIO CONVENCIONAL OU ELETRÔNICO, PARA FINS DE ESTUDO E PESQUISA, DESDE QUE CITADA A FONTE.

Catalogação na Publicação

Serviço de Biblioteca e Documentação

Faculdade de Educação da Universidade de São Paulo

374.9 Turbin, Ana Emília Fajardo

T931d Das lamentações às realizações possíveis: um estudo de caso com professores de inglês da rede pública de São Paulo / Ana Emília Fajardo Turbin; orientação Gláucia D`Olim Marote Ferro. São Paulo: s.n., 2010.

158 p.; il.; graf.; tabs.; anexos

Tese (Doutourado - Programa de Pós-Graduação em Educação. Área de Concentração: Linguagem e Educação) - - Faculdade de Educação da Universidade de São Paulo.

1. Formação continuada do professor 2. Ensino de língua estrangeira 3. Inglês (Estudo e ensino) 4. Reflexividade 5. Competência profissional I. Ferro, Gláucia D Olim Marote, orient. 


\section{FOLHA DE APROVAÇÃO}

Ana Emília Fajardo Turbin

DAS LAMENTAÇÕES Às REALIZAÇÕES POSSÍVEIS: UM ESTUDO DE CASO COM PROFESSORES DE INGLES DE INGLÊS DA REDE PÚBLICA DE SÃO PAULO

Tese apresentada à Faculdade de Educação da Universidade de São Paulo, para obtenção do título de Doutor em Educação.

Área de Concentração: Linguagem e Educação

Aprovado em:

Banca Examinadora

Profa. Dra. GLÁUCIA D'OLIM MAROTE FERRO

Instituição: FACULDADE DE EDUCAÇÃO - USP Assinatura:

Prof. Dr

Instituição:

Assinatura:

Prof. Dr.

Instituição:

Assinatura:

Prof.Dr

Instituição:

Assinatura:

Prof. Dr.

Instituição:

Assinatura: 
Dedico esta tese a meu irmão adorado, meu adorado irmão-Marcos- eternamente em meu coração. 


\section{AGRADECIMENTOS}

Aos professores Livia Donnini Rodrigues, Claudio Picollo, Vojislav Aleksandar Jovanovic, pelas brilhantes ideias, em diversos momentos da realização desta tese.

A Lina Mendes, maravilhosa revisora, de sensibilidade ímpar.

Aos professores da rede pública que me autorizaram a leitura e a utilização de seus escritos em diários e colaboraram dando entrevistas.

A Adriana Passarelli, grande professora.

A Sergio Mendes, que me acolheu em sua sala de aula.

A Paula Fajardo Archanjo, que me auxiliou com usos de ferramentas do computador.

A Mauro Mendes Dias, sempre por mim.

A Chiara Ferro Vieira, pela colaboração com a confecção das tabelas

A Carlos Ferro, pela paciência.

A Ray Turbin, pela ajuda com o abstract. 
AGRADECIMENTO ESPECIAL

A minha orientadora,

Gláucia D’Olim Marote Ferro, minha admiração e respeito. 


\section{RESUMO}

TURBIN, Ana Emília Fajardo. Das lamentações às realizações possíveis: um estudo de caso com professores de inglês da rede pública de São Paulo. 2010. 158 f. Tese (Doutorado) - Faculdade de Educação, Universidade de São Paulo, São Paulo, 2010.

Esta tese foi desenvolvida no campo da Formação Continuada do professor, mais especificamente do professor de Inglês, da rede pública de ensino. A hipótese levantada é a de que, em contextos de Formação Continuada, os professores são levados a expandir seus conhecimentos teórico-práticos. Ao mesmo tempo, focalizamos o surgimento de um comportamento mais voltado à reflexividade de sua prática, mostrado por meio das mudanças ocorridas em seus escritos - anotações efetuadas em diários e observações em sala de aula. Vinte e dois professores-sujeitos da pesquisa escreveram relatos, e quatro professores, inclusive a professora do curso, foram entrevistados e tiveram seus depoimentos gravados em áudio. Os resultados apurados, após um ano de comparecimento ao curso, e a análise dos dados revelaram momentos de observação e momentos dos registros nos diários. No primeiro momento, referente às observações, pudemos notar alguns estágios: (1) silêncio profundo; (2) olhar sobre si mesmo; e (3) busca de autonomia: um olhar sobre sua prática.

No momento dos registros em diários, pudemos categorizar: (1) muro das lamentações; (2) luz no fim do túnel; e (3) sinais de reflexividade: ação e controle.

Palavras-chave: formação continuada, ensino de inglês, reflexividade, competência. 


\begin{abstract}
TURBIN, Ana Emília Fajardo. From complaints to possible accomplishments: a case study of state school English teachers. 2010. 158 p. Theses. (Doctorate) Education Department, University of São Paulo, in 2010.

Our research comprises the field of English Teaching Continuing Education and we start from the assumption that in Continuing Education courses the teachers are given a chance to enlarge their theoretical and practical knowledge of English teaching while they are exposed to the course. We hypothesize that there will be some changes in their personal and professional life as they develop a reflective and critical teaching. To analyse these changes we chose to conduct a case study with State English teachers taking a methodology English course at a binational center located in the city of Sao Paulo, Brazil. The group selected was composed of 22 teachers who have been teaching English for at least 5 years, in state schools in Sao Paulo. The subject-teachers were asked to write their diaries while they attended the course in which they would register their interaction with their students in English classes. Also, 4 teachers were interviewed and their responses were recorded. The observation of the classes in the Methodology course took a year during which time the researcher took notes and took pictures of their group work. The results were categorized in two different moments. The first was the observation moment in which the researcher observed some stages such as: (1) profound silence; (2) egocentric talk; and (3) in search of autonomy: a look on their practice. The second was the moment of the diary analysis in which the researcher was able to get to the following categories: (1) mourning wall; (2) light at the end of the tunnel; and (3) signs of reflexivity: action and control.
\end{abstract}

Key-words: Continued education, English teaching, reflexivity, competence. 


\section{LISTA DE ILUSTRAÇÕES}

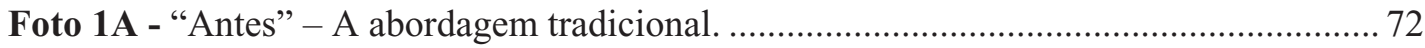

Foto 1B - "Depois" - novidades do método comunicativo. ................................................ 74

Foto 2 - Aspectos relevantes sobre uma nova maneira de lecionar Leitura em inglês .......... 75

Foto 3- Novos conhecimentos adquiridos pelo professor-aluno sobre como dar uma aula

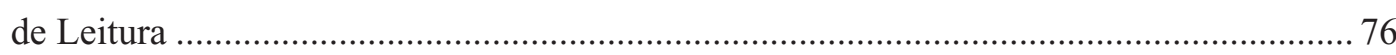

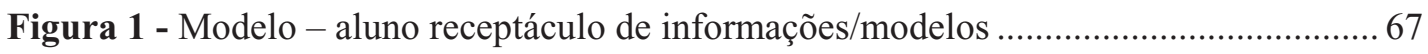

Figura 2 -Proposta de Ur para o desenvolvimento profissional do professor....................... 82

Figura 3 - Problemas desencadeadores de indisciplina ........................................................ 98 


\section{LISTA DE QUADROS}

Quadro 1: Formação Continuada do Professor:proposta e funcionamento do curso............ 51

Quadro 2: Ações/reações da Professora Melissa 105 


\section{LISTA DE TABELAS}

Tabela 1: Três momentos de análises 


\section{LISTA DE GRÁFICOS}

Gráfico 1: Frequência dos motivos desencadeadores de indisciplina 
INTRODUÇÃO ......................................................................................................... 15

As questões de pesquisa ...................................................................................... 15

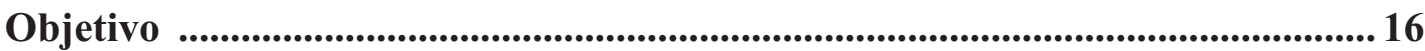

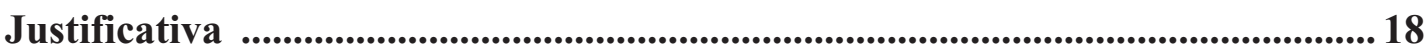

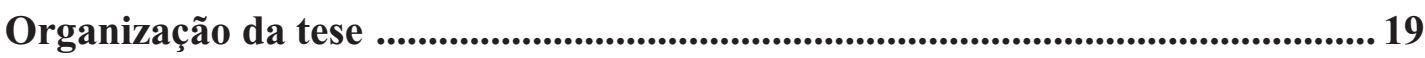

CAPÍTULO 1 - A FORMAÇÃO DE PROFESSORES DE INGLÊS: UM

EMARANHADO DE VISÕES, MODELOS E EXPECTATIVAS .................20

1.1. FORMAÇÃO DOCENTE: UM EMARANHADO DE VISÕES ..................... 20

1.2. FORMAÇÃO DO PROFESSOR DE INGLÊS: UM QUADRO DE

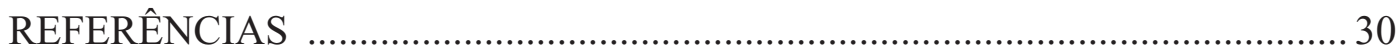

1.2.1. Cenários de formação........................................................................................ 30

1.2.2. Modelos de formação .............................................................................................. 35

1.2.2.1. O modelo de Kolb e as ampliações a esse modelo ....................................... 36

1.2.2.2. Os modelos de Wallace ........................................................................... 36

1.2.3. A noção de competência ................................................................................................... 38

1.2.4. Modelos de aprendizagem ....................................................................... 42

1.2.4.1. Trabalhar a partir dos erros e dos obstáculos à aprendizagem .................. 44

1.2.4.2. Construir e planejar dispositivos e sequências didáticas ............................ 44

1.2.4.3. Envolver os alunos em atividades de pesquisa, em projetos

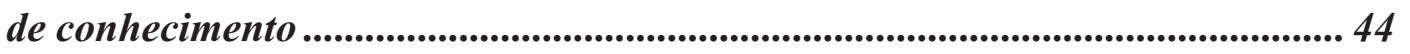

1.2.4.4. Estabelecer laços com as teorias subjacentes às atividades de

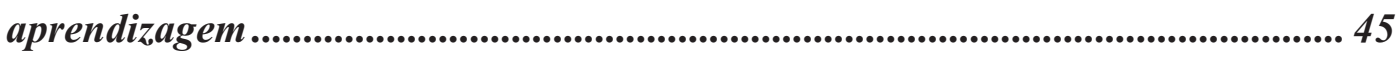


1.2.4.5. Observar e avaliar os alunos em situações de aprendizagem, de acordo com uma abordagem formativa 45

1.2.4.6. Fazer balanços periódicos de competências e tomar decisões de progressão 47

1.2.4.7. Participar da administração da escola........................................................ 47

1.2.4.8. Administrar sua própria Formação Contínua ......................................... 48

1.3. A FORMAÇÃO CONTINUADA DOS PROFESSORES DA REDE PÚBLICA 48

1.3.1. A formação continuada de professores de Inglês 48

1.3.2. Um espaço de formação do professor de Inglês: o curso de formação continuada analisado nesta tese 50

CAPÍTULO 2 - A PESQUISA. 53

2.1. O PORQUÊ DA PESQUISA E SUA ORIENTAÇÃO 53

2.2. OS DIÁRIOS. 57

2.2.1. A natureza dos dados dos diários. 57

2.3. A OBSERVAÇÃO COMO PROCEDIMETO DE COLETA DE DADOS ..... 59

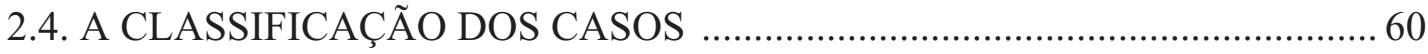

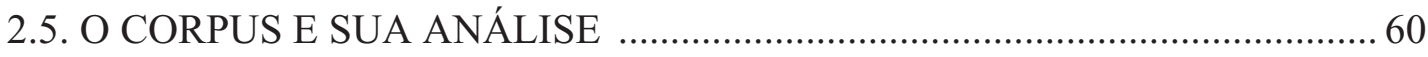

CAPÍTULO 3 - A ANÁLISE DO CURSO E SEUS RESULTADOS ................. 62

3.1. O CURSO DE CAPACITAÇÃO METODOLÓGICA: UMA VISÃO

PANORÂMICA DO CONTEXTO 62

3.2. O CURSO DE CAPACITAÇÃO METODOLÓGICA E SEUS OBJETIVOS 64

3.3. A TRAJETÓRIA DO CURSO E SEUS PRINCIPAIS MOMENTOS. 66 
3.3.1. "Silêncio profundo" 67

3.3.2. Fala egocêntrica: um olhar sobre si mesmo .................................................69 69

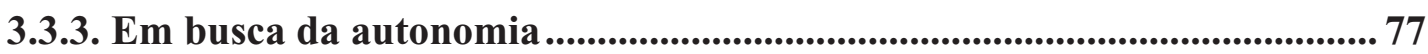

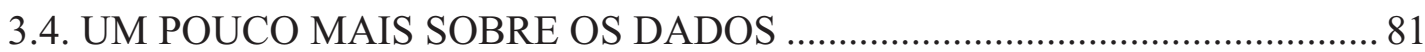

CAPÍTULO 4 - A ANÁLISE DOS DIÁRIOS E ENTREVISTAS:

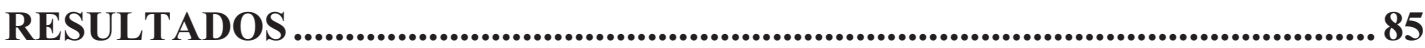

4.1.CONHECENDO UM POUCO MAIS AS CARACTERÍSTICAS DOS

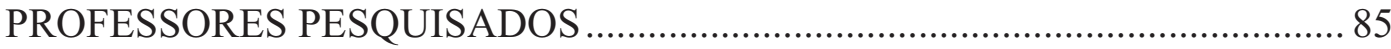

4.2. OS ESCRITOS E AS FALAS DOS PROFESSORES: UMA VISÃO

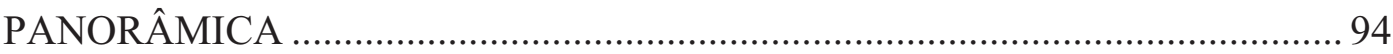

4.2.1. "Muro das lamentações": era uma vez ......................................................... 97

4.2.2. E a história continua: e de repente ............................................................ 102

CONSIDERAÇÕES FINAIS ...................................................................... 108

REFERÊNCIAS BIBLIOGRÁFICAS ............................................................ 111

ANEXO 1 - EXCERTOS DOS DIÁRIOS ESCRITOS...................................... 116

ANEXO 2 - RELATOS ORAIS (TRANSCRIÇÃO DE ENTREVISTAS

GRAVADAS EM ÁUDIO) ................................................................................ 144

ANEXO 3 - QUESTIONÁRIO APLICADO AOS PROFESSORES ................. 153

ANEXO 4 - TERMO DE AUTORIZAÇÃO PARA UTILIZAÇÃO DE

INFORMAÇÕES EM PESQUISA CIENTÍFICA ........................................ 154

ANEXO 5 - ENTREVISTA GRAVADA COM ARIADNE, NO DIA

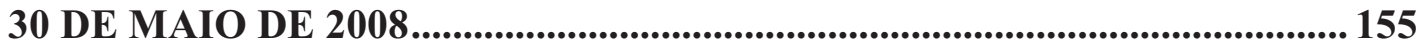




\section{INTRODUÇÃO}

(...) hoje eu vi na manchete do jornal que a escola de Primeiro Mundo, no Brasil, vai ser para 2030.

Professor Julian

Nossa pesquisa situa-se no campo da investigação da Formação Continuada do professor de Língua Estrangeira (LE) - Inglês - e nosso ponto de partida fundou-se na premissa básica de que, em contextos de formação continuada, seja trabalhada a ampliação dos conhecimentos teórico-práticos dos professores, prevendo-se reações e mudanças nesses profissionais. Tais reações e mudanças podem situar-se no plano pessoal, profissional e, até mesmo, econômico-social, especialmente no que diz respeito ao status que o curso possa lhes conferir.

Para investigar eventuais evidências dessas mudanças, escolhemos um curso de Formação Continuada para professores de Inglês das redes públicas - municipal e estadual de São Paulo, oferecido por Centro Binacional Brasil-Estados Unidos, na cidade de São Paulo, desde 1995. O formato e a estrutura desse curso contemplam, ao mesmo tempo, a ampliação e a atualização dos conhecimentos metodológicos do professor e também a prática e a melhoria de seu desempenho linguístico, por meio de aulas de Metodologia e também de Língua Inglesa.

Escolhemos para observação a parte do curso destinada à capacitação metodológica dos professores ${ }^{1}$, não só porque seria dada para a turma toda, mas também porque consideramos que, nesse segmento, trabalhar-se-iam propostas que visam à apresentação de diferentes abordagens de ensino e à reflexão sobre elas.

\section{As questões de pesquisa}

As seguintes questões de pesquisa foram inicialmente formuladas:

\footnotetext{
${ }^{1}$ Nas aulas de Língua Inglesa, os professores são divididos em grupos, de acordo com o seu nível de proficiência na língua.
} 
1. São observadas reações/mudanças nesses professores, no decorrer do curso de Metodologia? Em caso positivo, quais são os indicadores dessa mudança?

2. Dentre as possibilidades de efeitos provocados pelo curso, especialmente vinculados a propostas de novas abordagens acerca das formas de ensinar a língua, há indícios da emergência de uma nova postura dos professores?

Estabelecido o foco da pesquisa, bem como a escolha do locus e as perguntas de pesquisa, formulamos outras indagações complementares, a fim de orientarmos o estudo em direção a:

1. Como são capacitados os professores de LE da rede pública nos cursos de formação continuada? Como são organizados os cursos? Qual a sua orientação?

2. Ao participarem desses cursos, os professores estão realmente interessados em pensar sobre a sua prática? Em que momento da sua carreira os professores optam por cursos dessa natureza?

3. Havendo a expectativa de novas abordagens e processos de reflexão nesses cursos, há realmente alguma alteração representativa de mudanças na prática docente desses professores? Em caso positivo, no decorrer do curso, quais são as mudanças detectadas?

\section{Objetivo}

Estabelecidas as perguntas de pesquisa, o objetivo principal deste estudo é apontar mudanças na prática do ensino de LE desses professores de escolas públicas, sublinhando-se, nessas mudanças, a perspectiva de desenvolvimento de uma postura reflexiva. Como instrumento para a obtenção dos dados, foi proposto o registro das observações do curso e o registro das ocorrências e experiências dos professores, em diários, elaborados à medida que o curso se desenvolvia.

Quatro dos participantes do curso que se dispuseram a participar complementaram os dados e a sua análise.

Partimos do pressuposto de que poderia haver mudanças nos registros dos professores, durante o período em que comparecessem ao curso e, concomitantemente, refletissem acerca de sua prática e não esperávamos, inclusive, que essa mudança ocorresse sem obstáculos. E, realmente, o primeiro deles residiu nas dificuldades de escrita apresentadas 
pelos informantes; do mesmo modo, as capacidades de expressar-se e narrar, articulando logicamente as idéias, também se mostraram como elementos que comprometeram o registro regular nos diários, por parte dos participantes da pesquisa. A própria motivação para o ato de escrever influenciou nos resultados apresentados, já que metade dos professores-alunos entregou apenas dois escritos: um no início do curso e outro ao seu final. A solicitação para que fosse escrito um relato de momentos da sua aula de LE erigiu, no início, um muro de lamentações feitas pelos professores-alunos e, aparentemente, isso funcionou como um pedido de redenção, uma demanda de compreensão pelas dificuldades que os professores enfrentam nas escolas. Um elenco de problemas foi, portanto, registrado no corpus, vistos também como dados importantes e ilustrativos das escolas de rede pública em que esses professores atuam. Tais problemas ${ }^{2}$ também serviram de referência e suporte para a investigação das eventuais mudanças que poderiam ocorrer: mudanças de atitudes e de discurso, ao longo do curso de Capacitação.

Assim, com a associação de aulas de Inglês a um contexto desprovido de condições para ensinar, aos poucos, poderiam surgir possibilidades de um novo olhar sobre a realidade de ensino desses professores. Uma oportunidade de vivenciar outra prática de ensino de LE, pautada em princípios claros e objetivos que pudessem levar o sujeito a sentir-se como pertencente a uma comunidade, capaz de comunicar-se em uma LE e trabalhar com autonomia. Esse, portanto, era o objetivo maior do curso oferecido a esses professores.

Esta pesquisa não contemplou a verificação de mudanças no locus em que o professor efetivamente atua, ou seja, na sala de aula da rede pública, muito embora admita como pressuposto que as informações inseridas nos diários sejam verdadeiras. Os dados coletados referem-se ao tempo em que a pesquisadora acompanhou o curso e teve acesso aos diários dos professores, entrevistas e observações de aulas desses professores como alunos do curso. As análises daí decorrentes restringem-se, portanto, ao período em que o curso ocorreu.

\footnotetext{
${ }^{2}$ Sousa (2006, p.486) relata comportamento semelhante em relação aos sujeitos-professores entrevistados por ela. Diz-nos a autora que aqueles "que se dispõem a ouvir de fato os professores devem estar preparados para entrar em contato com suas angústias, dúvidas e, especialmente, queixas advindas do exercício de uma prática profissional repleta de desafios, que são, via de regra, enfrentados na solidão. Praticamente todas os professores tomaram a entrevista como uma oportunidade de protestar, desabafar e compartilhar um pouco de sua história profissional. Assim, ao falarem sobre seu trabalho e sobre o curso que estavam frequentando, o discurso desses professores era por vezes errático, com alterações frequentes de assunto. Manifestações de insatisfação com as condições de trabalho oferecidas nas escolas apresentavam-se em vários graus e de diversas maneiras, no grupo".
} 


\section{Justificativa}

Como já salientado, o curso de Capacitação que serviu de base para a pesquisa tem como foco a capacitação metodológica e linguística do professor e é tratado como espaço para uma prática reflexiva. Justifica-se, portanto, investigação sobre a sua eficiência. No entanto, para que esse professor de LE da escola pública torne-se um profissional orientado para a ação pedagógica, é necessário ter a seu dispor saberes que o guiarão frente aos problemas do dia a dia. No dizer de Perrenoud (2008, p.11), esses saberes - inúmeros, aliás centram-se no domínio teórico e prático de processos de ensino e aprendizagem, visando a uma formação realmente profissional. Quando desconhecidos pelo professor, problemas externos ao logos pedagógico acabam por ter prioridade, mesmo que esse profissional não tenha responsabilidade única por eles e, muitas vezes, não saiba como enfrentá-los.

Vemos, portanto, nessas orientações de Perrenoud, outra justificativa para investigar o contexto por nós escolhido e delinear a possibilidade de abrangência do curso oferecido aos professores, na medida em que possibilita, também, ampliar os conhecimentos ligados aos conteúdos nas aulas de Língua e ao exercício e prática docente, nas aulas de Metodologia. Com isso, a expectativa de mudança nesses indivíduos poderá ter maior possibilidade de ocorrência.

A ideia de competência é também focalizada por Machado (2009). O autor busca definir a palavra competência e afirma que ela surgiu no discurso educacional na última década do século XX, sendo o seu uso bastante recente nos meios educacionais. Entraremos, posteriormente, em maiores detalhes sobre o conceito de competência, desenvolvido por autores estudiosos do tema; por ora, contudo, ficaremos com a ideia inicial de que uma pessoa competente é aquela capaz de mobilizar o que sabe, para realizar o que deseja (MACHADO, 2009, p.26). Procuraremos observar, ao longo deste estudo, o alcance de um curso de Formação, tal como o aqui analisado, para a "construção" e viabilização dessa ideia em sala de aula. 


\section{Organização da tese}

Esta tese está organizada em 4 (quatro) capítulos, antecedida de Introdução e complementada pelas Considerações Finais. Além disso, estão também incluídos a Bibliografia e o conjunto de anexos no final do trabalho.

O primeiro capítulo irá tratar de conceitos relacionados à formação docente e modelos de formação, a partir de uma retrospectiva histórica da chamada Formação Continuada e seus aspectos de maior relevância, dentre eles, a noção de competência profissional.

No segundo capítulo, serão apresentadas teorias que fundamentaram a metodologia aqui utilizada, de cunho etnográfico, e que serviram de base para a obtenção e análise dos dados.

A análise do curso e seus resultados serão apresentados no capítulo 3, com base na interpretação das observações feitas ao longo do curso de capacitação metodológica. Nele, puderam ser detectados momentos distintos, que serão descritos em detalhe no decorrer do capítulo.

O quarto capítulo complementa a análise do curso de formação, com os resultados do estudo dos diários e entrevistas dos professores, participantes da pesquisa. Esses registros serão analisados à luz de teorias apresentadas no capítulo 1 e serão definidas as três “configurações textuais" encontradas, cada uma com diferentes características em relação à forma e aos temas tratados. Esses diferentes registros parecem ser indicadores de um processo de mudança ocorrido ao longo do curso e reflexo da sua organização e orientação.

Nas Considerações Finais, de mistura com a síntese de todo o trabalho, esperamos deixar alguma contribuição para estudos futuros, no que tange à Formação Continuada de professores de Inglês e seus resultados, bem como da organização e orientação de cursos de Formação, em consonãncia com a ação pedagógica e a instituição de uma prática reflexiva. 


\title{
CAPÍTULO 1 - A FORMAÇÃO DE PROFESSORES DE INGLÊS: UM EMARANHADO DE VISÕES, MODELOS E EXPECTATIVAS
}

\author{
Organizei-os em círculo e fizemos uma dinâmica na qual cada um pôde \\ interagir melhor com o professor e os colegas. Percebi que o ambiente ficou \\ mais tranquilo, que eles ficaram mais curiosos e a dinâmica agradou. \\ Professora Sofia
}

Neste capítulo discorreremos sobre conceitos relacionados à formação docente e seus aspectos de maior relevância.

Faremos, ainda, uma retrospectiva histórica das denominações da hoje chamada Formação Continuada e percorreremos as emaranhadas vias dessa trajetória em que diversos autores manifestam seus pontos de vista sobre as possibilidades de aprimoramento do professor. Salientaremos também modelos de formação, com suas características próprias, abordando, por fim, a noção de competência profissional, para chegarmos ao modelo de formação dos participantes deste estudo.

\subsection{FORMAÇÃO DOCENTE: UM EMARANHADO DE VISÕES}

A formação docente pressupõe processos educativos de aprendizagem com vistas à atuação profissional. A chamada Formação Inicial refere-se ao processo oficial em que são ministrados cursos que compõem o currículo universitário - em nossa pesquisa, os cursos de Letras e Licenciatura que preparam alunos para a docência em Língua Estrangeira (Inglês). Formar, nesse estágio inicial, para Fusari (1988, p.45), é um termo que tem sido usado no sentido de habilitar para e "designa a qualificação com certificação. Trata-se do processo de formação profissional, através do sistema formal de ensino, em que ao final o sujeito adquire oficialmente (legalmente) a habilitação para o trabalho".

Por sua vez, Formação Continuada, como abordada nesta tese, constitui-se em um processo posterior, necessário ao desenvolvimento, aperfeiçoamento ou capacitação de 
qualquer profissional, em especial o profissional de ensino, seja a Formação Inicial considerada deficiente ou não. O termo capacitação docente é muitas vezes utilizado para programas de Formação Continuada. Desse modo, neste trabalho, as expressões formação continuada e capacitação de profissionais serão utilizadas como sinônimas, ainda que pesem divergências semânticas em relação aos dois termos. A Lei de Diretrizes e Bases (1996) em seu artigo 63, inciso III, determina que "os institutos superiores de educação manterão programas de formação continuada para os profissionais de educação dos diversos níveis”. No artigo 67, inciso V, determina, ainda, que "os sistemas de ensino promoverão a valorização dos profissionais da educação, assegurando-lhes [...] período reservado a estudos, planejamento e avaliação, incluído na carga de trabalho".

A situação real nas escolas mostra, no entanto, que essas horas incluídas na carga horária dos professores e que deveriam ser dedicadas ao efetivo planejamento e desenvolvimento do profissional de ensino e do seu trabalho pedagógico na escola, na maioria das vezes são consumidas por tarefas triviais tais como correções de provas, reprodução de programas e preparação de materiais. Raras são as escolas nas quais essa determinação legal é posta em prática, a serviço da escola e do profissionall de ensino, restando àqueles efetivamente interessados buscar, em horários livres, quando existirem, situações de aprimoramento profissional.

Sousa (2006, p.483) aponta, aliás, a tendência crescente de se oferecerem cursos de Formação Continuada, concretizados "no estabelecimento de diversos convênios entre secretarias municipais e estaduais de Educação e as universidades públicas e privadas [...] no formato de cursos, seminários, encontros, conferências e congêneres". Entretanto nem sempre os professores conseguem usufruir desse benefício, atrelados que estão às exigências de seu cotidiano na escola, que em muitos casos não está em condições de dar-lhes apoio e incentivo para o desenvolvimento profissional. Há, inclusive, situações descritas pelos professores, revelando escolas que não comunicam a oferta dos cursos, diretores que negam permissão para participação em eventos dessa natureza, e sobreposição dos horários do trabalho do professor e da oferta de tais eventos.

Para alguns profissionais, a participação nesses eventos também não é motivadora, seja pelo parco reconhecimento na carreira, por meio de pontuação nem sempre atrativa; seja pelo tratamento recebido, pois o professor é muitas vezes visto como responsável pelo insucesso da educação. Sousa, nesse sentido, identificou em muitos cursos de Formação a presença do argumento da incompetência, que sustentaria a crescente 
importância de tais ofertas: estariam atrelados à má-formação inicial dos professores, que, não sabendo lidar com a diversidade dos alunos, especialmente os provenientes das camadas populares, deveriam melhorar sua competência para tanto.

Mas, o professor não pode ser considerado culpado de uma situação que abrange uma gama de outros problemas, entre eles a heterogeneidade que caracteriza o dia a dia de nossas escolas, como argumenta Sousa (2006, p. 483). A autora (Ibid., p.481) lembra-nos, a propósito disso, a pesquisa etnográfica de Patto (1990), que apresenta descrição analítica minuciosa da vida cotidiana de uma escola pública. Diz ela:

Ao investigar as causas do fracasso escolar, Patto analisa as práticas e os processos escolares a partir da dimensão dos sujeitos: professores, pais e alunos. Tal como concebido por Heller $(1972 ; 1987)$, esses sujeitos são portadores de uma história de vida, de uma visão de mundo e de uma práxis que não pode ser entendida apenas no âmbito de conceitos de ideologia dominante e das relações de classe.

Ao questionar preconceitos e estereótipos sociais, assim como uma visão psicologizante, que muitas vezes "situa no aluno e em sua família as razões de seu insucesso escolar e social", o trabalho de Patto detecta, pelo contrário, no interior da escola e do sistema escolar, a existência de práticas responsáveis por muitos dos problemas existentes:

fomentando a estigmatização de grupos de alunos considerados fracos, práticas de remanejamento - nem sempre antecedida pela necessária preparação do aluno -, fazendo com que algumas crianças tenham vários professores em um só ano; o desrespeito no trato com crianças, subjacente ao hábito comum de repreensões e humilhações públicas, minando sua autoimagem, ainda em processo de formação; a submissão dos alunos, em grupos de reforço escolar, a exercícios tediosos e atividades desprovidas de significado (Ibid., p.482).

Os exemplos acima mostram a necessidade de se pensar de forma mais abrangente a prática escolar. Certamente um curso de Formação Continuada não se deve limitar a propostas de ensino que visem fundamentalmente a sanar incompetências do professor, mas deve ensinar outras competências. A noção de competência aqui adotada vai além do saber fazer; abrangendo práticas inovadoras que almejam o desenvolvimento da cidadania, do desenvolvimento da pesquisa e da prática reflexiva. Perrenoud (2000) - um dos autores que estudam a escola do século XXI e a formação de profissionais que nela possam atuar - propõe competências que ultrapassam o ambiente escolar, que abrangem os dilemas éticos da profissão docente, que envolvem os pais dos alunos e, ainda, que ampliam a participação do professor na escola.

Nesse sentido, o objetivo de cursos de Formação Continuada não deve apenas visar ao desenvolvimento da competência dos professores do curso; muito pelo contrário, a 
melhoria da qualidade das escolas deve ser considerada como de suma importância e, para tal, deve estar aliada a uma proposta de trabalho permanente com os professores.

Mas é preciso lembrar que a preocupação com a melhoria da qualidade da Educação e propostas de desenvolvimento do profissional de ensino não é nova e vários nomes têm sido dados aos diversos cursos para aprimoramento de professores, no decorrer dos anos.

O termo Reciclagem, por exemplo, surgiu na década de 1980, envolvendo profissionais de várias áreas, entre elas a Educação. Segundo Hypollito (2000, p.101), reciclar supõe um movimento circular mais adequado a coisas do que as pessoas, como a reutilização de materiais usados ou não degradáveis, para outros finns. Então, a ideia distancia-se daquela da atualização pedagógica, uma vez que o material reciclado passa por transformações radicais. E podemos considerar que Reciclagem foi um termo usado no meio educacional, para referir se a "cursos rápidos e descontextualizados, envolvendo o ensino de forma geralmente muito superficial, com raras exceções" (Ibid.,p.101).

Já o termo Treinamento, ainda hoje utilizado na área de Recursos Humanos e em muitas escolas, incluindo as de idiomas, implica repetição mecânica e passividade de quem é treinado, remetendo-nos a uma ideia de adestramento de animais e não ao desenvolvimento do conhecimento, ao uso da inteligência. Para Ferreira (1985, p.67 apud HYPOLITTO, 2000, p.101), "treinamento é uma atividade organizada, metódica e sistematicamente conduzida para se atingir determinada parte de um problema específico de produção". No caso da Educação, diz-nos Fusari, aliás, que o indivíduo diploma-se, mas não domina os conteúdos de ensino, não sabe ensinar e não compreende a dimensão política de seu trabalho. Treinamentos eram então oferecidos como forma de suprir aquilo que o processo regular de ensino não estaria conseguindo fazer: formar bem o profissional da Educação (FUSARI, 1988, p.45). E o autor indaga se esses treinamentos "conseguem superar as lacunas da formação profissional desenvolvida pelo sistema regular de ensino" (Ibid., p.45). Para ele, as razões que levam o professor a buscar treinamentos podem ser consideradas "manifestações de um problema mais central, que é a própria crise de identidade que esse profissional vive”. Para o autor, a falta de reconhecimento do professor está refletida em "sua luta para assumir plenamente sua condição de cidadão, na sua prática social global” (Ibid., p.74). De qualquer forma, treinamentos geralmente se atêm a modelos prévios que, ao serem propostos e trabalhados no grupo de profissionais envolvidos nessa atividade, são esperados efetivamente como modelos a serem reproduzidos tal e qual. Além da relação intrínseca com modelos de Formação, que 
serão apresentados mais adiante, a visão de treinamento apoia-se na crença de que existe um modelo idealizado, melhor do que qualquer outro.

Do mesmo modo, o termo Aperfeiçoamento também traz inadequações em seu significado: tem o sentido de tornar perfeito, completar o que está incompleto. Para Hypolitto (2000, p.102), na rede oficial do Estado, cursos de Aperfeiçoamento com carga horária de 180 horas ainda são oferecidos em períodos que, em tese, permitiriam a frequência do docente fora de seu horário de trabalho, mas nem sempre é o que acontece; por vezes, a pontuação obtida nesses cursos constitui o fiel da balança, quando da atribuição de aulas, ao reforçar a titulação do portador. No entanto, muitos desses cursos, hoje, não oferecem ao participante pontuação atrativa: a participação em dois eventos de 30 (trinta) horas cada, muitas vezes oferece a esse participante o mesmo número de pontos de um curso de 180 (cento e oitenta) horas.

Atualização, por sua vez, carrega o sentido de tornar atual o conhecimento do professor, considerado desatualizado pela rotina do dia a dia e pelo seu afastamento, pelo distanciamento do processo de formação. Hypolitto faz uma ressalva no que diz respeito à atualização, observando que o professor deve estar preparado para questionar "em que medida os novos conhecimentos que adquire podem ajudá-lo a melhorar a sua prática". Para Fusari (1988 apud HYPOLITTO, 2000, p.102), atualizar significa colocar o educador em contato com aquilo que é atual, com os últimos conhecimentos produzidos na sua área, os quais devem ser encontrados nos resultados de estudos e pesquisas recentemente concluídos e que, muitas vezes, acabam ficando nas prateleiras das bibliotecas, sem que o professor que está na escola tenha acesso a esse saber.

A partir dos anos 1960, a capacitação dos recursos humanos para a Educação passou a significar um conjunto de ações - cursos, encontros, seminários - com o objetivo de desenvolver a qualificação do professor. Diz-nos Hypolitto que essa capacitação deve ir muito além de uma ação de treinamento, pois envolve alterações na visão do mundo e nos valores desse professor. Marin (1995, p.17 apud HYPOLITTO, 2000, p.102) explica que "os profissionais da Educação não podem, e não devem ser persuadidos ou convencidos de ideias; eles devem conhecê-las, analisá-las, criticá-las, até mesmo aceitá-las, mas mediante o uso da razão".

Para Fusari (1988, p.50), o conceito de capacitação, em Educação, partiu da área de Recursos Humanos, no processo produtivo capitalista, "no qual o homem é concebido como meio para, e o trabalho entendido como sinônimo de exploração". O autor propõe que 
se pense em outra forma de aperfeiçoar o educador, uma proposta compatível com "um posicionamento em que a educação escolar seja vista como um processo importante na formação do homem, no sentido de instrumentá-lo através da especificidade do trabalho escolar - para a prática social concreta" (FUSARI, 1988, p.50).

Para o autor, a capacitação de recursos humanos no enfoque empresarial "tem um compromisso com a adaptação do sujeito às condições do processo produtivo, e a educação do educador em serviço tem um compromisso com a crítica desse processo e a ampliação da consciência de educador em relação a complexas e contraditórias relações entre educação escolar e trabalho" (FUSARI, 1988, p.55). Ele acredita que, no âmbito educacional, "o conceito de capacitação de recursos humanos, sob a ótica da teoria do capital humano, significa reduzir o educador à condição de meio, significa admitir que a atuação seja igual e tenha a mesma finalidade no processo produtivo". O autor salienta que na "educação do educador, a meta é a ampliação da sua consciência" em relação "a seu papel técnico-político no ato educativo escolar, tendo em vista a formação crítica do educando" (Ibid., p.55), e conclui que a educação escolar é o "processo que deve interferir na passagem da consciência ingênua do sujeito para a consciência crítica" (Ibid., p.50). Concordamos com o autor sobre a necessidade da consciência crítica do educador e esperamos que o desenvolvimento dessa consciência nos profissionais de ensino garanta, de fato, a melhoria da Educação.

Nesse ponto de vista, a linha atual da Formação Continuada, ou Educação Contínua, constitui um passo importante na busca dessa melhoria. Formação Continuada abordada aqui como projetos que almejem o desenvolvimento profissional e pessoal do professor, visando à melhoria da qualidade de ensino e, por conseguinte, da Educação. Assim, o professor deve seguir cursos de Capacitação não necessariamente em virtude de uma formação inicial precária e não somente em busca de competência(s), o que seria um parâmetro bastante limitador, mas dentro de um pensamento abrangente em que ele se torne crítico dos próprios atos e possa, assim, atuar de maneira cada vez mais consciente e efetiva. O que propomos está de acordo, portanto, com uma visão de que o processo ensinoaprendizagem não para, não tendo começo nem fim. Em qualquer campo do saber, o movimento de conhecer o novo - ou aquilo que pelo menos não é tão bem conhecido, mesmo que não seja tão novo assim - é um processo que transforma e pode levar a uma reflexão e a um novo ato educativo. Justificar, então, a importância de cursos de Formação Continuada como uma equação resultante da má formação inicial do professor seria reduzi-lo a simples 
repetidor de receitas didáticas ou esperar dele um ofício marcado por um mecanicismo irresponsável.

Monteiro e Giovani (2004, p.130) estabelecem alguns pressupostos norteadores para ações de Formação Continuada, bem como duas grandes características desse processo:

1. troca de saberes. Respeito aos saberes dos professores participantes de um processo de educação continuada, promovendo troca de conhecimentos. Dessa troca resulta um "novo" conhecimento para as duas partes envolvidas (Monteiro e Giovani, 2004, p.131);

2. atitudes diante do novo. "As reações dos professores podem variar desde o desejo e o esforço da aprendizagem até o total bloqueio e resistência ao novo" (Ibid., p.131). A presença de professores receptivos tem se mostrado fator fundamental para estimular atitudes de interesse e envolvimento.

As autoras ainda adicionam alguns indicadores de envolvimento por parte dos professores, relacionando-os a um conjunto de sinais: o das expressões faciais, gestos, posturas corporais, expressões do olhar (Ibid., p.131).

Hernandez (1998 apud MONTEIRO; GIOVANI, 2004, p.133), por sua vez, constata regularidades em atitudes de professores, em situações de Formação Continuada:

a. refúgio no impossível. Apesar de reconhecerem a importância de uma informação nova, os professores não reconhecem a possibilidade de sua adoção ou adequação à prática;

b. desconforto em aprender, resistências ao esforço de aprender;

c. revisão da prática não resolve os problemas: os professores preferem receitas de como ensinar a se submeterem a um processo de reflexão sobre a prática;

d. aprender ameaça a identidade: medo de negar ou contrariar sua própria bagagem de conhecimento;

e. separação entre fundamentação e prática (os professores apegam-se a uma falsa definição de papéis, segundo a qual cabe a eles a execução, e à universidade, a investigação e busca de conhecimento.

Para Monteiro e Giovani (2004, p.133), tais atitudes não se manifestam sempre e da mesma maneira.

Ao contrário, elas se manifestam de forma alternada e inconstante, resultando em situações a que a equipe de pesquisadores da qual fazem parte as autoras acostumou-se a denominar de "altos" e "baixos" do processo, e que acarretam, por sua vez, a demora característica na efetivação de resultados do processo de formação continuada de professores.

Essa característica que Monteiro e Giovani (2004, p.133) destacam como "demora do processo" pressupõe a existência de um movimento natural em que também há progressos 
e retrocessos relacionados à história de vida pessoal e profissional dos professores, diferenças nas trajetórias escolares, na formação e experiências, "marcadas por práticas pouco democráticas, que trazem dificuldades no tocante ao desempenho dos professores no falar, no escrever, no perguntar, no estabelecer relações entre a escola e o mundo fora dela" (Ibid., p.134).

Para as autoras, a tendência de professores em esperar pela receita pronta, em trabalhar de forma individualizada, está vinculada a tais práticas e, a esse respeito, vale lembrar o estudo de Huberman (2000, p.47), que classifica as fases da carreira do professor, associadas à idade e ao tempo de serviço. O autor (2000) resume as principais características das etapas, na carreira do professor, descrevendo sete fases: (1) entrada na carreira; (2) estabilização; (3) diversificação; (4) questionamento; (5) serenidade; (6) conservantismo ${ }^{1}$ e lamentações; (7) desinvestimento.

Tais fases serão descritas em detalhes, quando retomadas para a perspectiva de análise que faremos nos capítulos posteriores, cientes de que elas são apenas manifestações possíveis no decorrer da carreira docente.

Observamos, também, frente às marcas da trajetória histórica e sociopedagógica de diferentes tendências de formação, aquela que emerge de uma concepção de reflexão, encontrada no pensamento de autores tais como Schön, Perrenoud e Freire.

Araújo Silva e Martins de Araújo (2005, p. 3-4) resgatam o trabalho de Freire e estudam concepções ligadas ao processo de Formação Continuada, em que "a reflexão é o movimento realizado entre o fazer e o pensar, entre o pensar e o fazer, ou seja "pensar para fazer" e "pensar sobre fazer". Nessa direção, "a reflexão surge da curiosidade sobre a prática docente". E tal curiosidade, afirmam, inicialmente é ingênua; no entanto, com o exercício constante a curiosidade vai se transformando em crítica. Dessa forma, "a reflexão crítica permanente deve constituir-se como orientação prioritária para a formação continuada dos professores que buscam a transformação de sua prática educativa.” (op.cit, 2005). Essa reflexão, para os autores, deve constituir a orientação da prática educativa permanente, seguindo o pensamento freiriano de que o homem é um ser inconcluso e deve ser consciente de sua inconclusão, através do movimento do ser e saber mais. (FREIRE, 2002 apud ARAÚJO SILVA; MARTINS DE ARAÚJO, 2005, p.4)

\footnotetext{
${ }^{1}$ Estado de espírito, tendência daqueles que são hostis às inovações políticas e sociais; tradicionalismo. (www.dicio.com.br)
} 
A formação do professor assume, nessa visão, uma posição de prevalência nas discussões relativas à Educação, numa perspectiva transformadora. Essa é uma preocupação evidenciada nas investigações mais recentes e na literatura da área, provocando debates e encaminhando propostas acerca da formação inicial e continuada de docentes. Neste momento mundial, como já salientamos, a Formação Continuada ocupa lugar de destaque, associada ao processo qualitativo de práticas formativas e pedagógicas (PORTO, 2004, p.11).

Ainda segundo essa autora, as concepções sobre Formação Continuada confrontam-se no âmbito educacional, podendo ser reunidas em duas grandes tendências:

1. estruturante: formação tradicional, comportamentalista, tecnicista, em que se definem previamente programas, procedimentos, recursos, a partir de uma lógica de racionalidade científica, técnica, aplicada aos diversos grupos de professores (NÓVOA, 1992, p.21 apud PORTO, 2004, p.12);

2. interativo-construtivista: dialética, reflexiva, investigativa, orienta-se a partir dos contextos educativos e das necessidades dos sujeitos a quem se destina.

Nessa perspectiva, a formação do professor é indissociável de sua experiência de vida. A formação do professor é um processo que não se finaliza com a formação inicial; ao contrário, impõe-se como continuidade indispensável; dá-se enquanto acontece a prática e por essa razão não se conclui; cada momento abre possibilidades para novas etapas de formação, assumindo um caráter de recomeço, renovação, inovação da realidade pessoal e profissional, tornando-se a prática a mediadora da produção do conhecimento ancorado, mobilizado na experiência de vida do professor e em sua identidade, uma prática interativa e dialógica entre o individual e o coletivo (Ibid., p.14).

Garcia (1995 apud PORTO, 2004, p.21) destaca três atitudes fundamentais em relação à formação e à prática pedagógica reflexiva: (1) responsabilidade; (2) mentalidade aberta; (3) entusiasmo.

Esse modo de perceber a "prática" e orientar a ação pedagógica evidencia possibilidades de:

a. romper com o conformismo;

b. superar a rotina;

c. desenvolver a atitude de andar sempre de olhos abertos, vendo o mundo criticamente, reconstruindo-o pelo questionamento permanente.

d. descobrir e produzir novos conhecimentos; 
e. transmudar o quadro educacional-pedagógico, que passa a acolher questionamento e a ressignificar a verdade, encontrando e construindo caminhos para a autonomia (PORTO, 2004, p.27).

A formulação sartreana sobre ser pessoa e ser professor é: $O$ homem define-se pelo que consegue fazer com o que os outros fizeram dele (SARTRE, s.d.) ${ }^{2}$. E essa citação leva-nos, de certa forma, a descrever a prática do professor de Inglês da rede pública.

$\mathrm{O}$ professor, frente à classe, traz toda sua experiência anterior não somente como professor, mas também como aluno; traz crenças e atitudes para dentro dos muros da escola e seu modo de ensinar estará condicionado a todas as situações vivenciadas por ele. Nóvoa (2000, p.17) afirma que a maneira como cada professor ensina está diretamente dependente daquilo que ele é como pessoa, quando exerce o ensino. Para o autor (Ibid., p.16-17), é impossível "separar o eu profissional do eu pessoal. [...] o professor reveste-se de uma segunda pele", a que ele denomina segunda pele profissional, "que recobre a pessoa e o profissional" ou, em outras palavras, remete-nos ao ser indivíduo e ao ser professor, como duas faces da mesma moeda, um sujeito constituído singular.

De acordo com Gadotti (2008, p.46), a Formação Continuada do professor em serviço é um direito. Diz-nos o autor que, a fim de que esse direito seja exercido na prática, algumas exigências mínimas seriam necessárias. E, dentre essas exigências, menciona:

$\mathbf{1}^{\mathbf{0}}$. direito a, pelo menos, 4 horas semanais de estudo com os colegas, não só com especialistas de fora, para refletirem sobre sua própria prática, dividirem dúvidas e resultados obtidos;

$\mathbf{2}^{\mathbf{0}}$. possibilidade de frequentar cursos sequenciais aprofundados em estudos regulares, sobretudo sobre o ensino das disciplinas ou campos do conhecimento de cada professor;

$\mathbf{3}^{\mathbf{0}}$. acesso a bibliografia atualizada;

$4^{\mathbf{0}}$. possibilidade de sistematizar sua experiência e escrever sobre ela;

$5^{\circ}$. possibilidade de participar e expor sua experiência em congressos educacionais;

$\mathbf{6}^{\mathbf{0}}$. possibilidade de publicar a experiência sistematizada;

$\mathbf{7}^{\mathbf{0}}$. não só sistematizar e publicar suas reflexões, mas também colocar em site da Secretaria da Educação.

\footnotetext{
${ }^{2}$ Intervox NCE/UFRJ. Disponível em: $<$ http://intervox.nce.ufrj.br/ ballin/sartre2.doc $>$. Acesso em: 18 jun. 2008.
} 


\subsection{FORMAÇÃO DO PROFESSOR DE INGLÊS: UM QUADRO DE REFERÊNCIAS}

Ao tratarmos da formação do professor de Inglês, devemos primeiramente salientar que tal formação, inicial ou continuada, segue, na grande maioria dos casos, os mesmos parâmetros de outros profissionais que atuam na escola, responsáveis pelo ensino de outras disciplinas do currículo escolar, tais como Matemática e História, entre outras. No entanto, é importante ressaltar o fato de que para muitos desses profissionais o "parco conhecimento" que possuem sobre o conteúdo que ministram na escola muitas vezes pode ser escamoteado. Entretanto, no caso específico do professor de Inglês (e de outras Línguas Estrangeiras), não saber (ou saber pouco) a língua que ensina traz ao indivíduo grande desconforto pessoal e profissional, bem como dificulta sua reflexão sobre a prática docente, pela interferência direta que existe sobre o fazer e o pensar. Uma vez que a formação desse professor é um processo que implica continuidade e novos conhecimentos e que sua prática docente, ancorada nesse parco conhecimento da língua, trará a ele, como pessoa e como profissional, sentimento de incapacidade e frustração, resta a esse profissional "carente" assumir sua ignorância e ir à busca desse saber. Nesse sentido, qualquer possibilidade para novas situações de uso e aprendizado da língua, formais ou informais, deve ser buscada. $\mathrm{O}$ professor, inclusive, deve assumir atitude responsável, mentalidade aberta e entusiasmo pelo desenvolvimento dessa competência, fundamental para o exercício profissional. O único percurso a fazer é aceitar essa limitação e agir no sentido de minimizá-la cada vez mais.

\subsubsection{Cenários de formação}

De acordo com Rodrigues (2003, p.143), “o cenário em que se insere a atuação dos profissionais da área de Educação em geral e, em particular, dos professores de Língua Inglesa impõe desafios e exigências para os quais grande parte dos professores, dada sua formação inicial, não se vê preparada para enfrentar".

Ferro (1998, p.144) constata, em seu estudo sobre a formação inicial do professor de Inglês, na Universidade de São Paulo, a adesão de um modelo de formação profissional idealizado. Diz a autora que esse tipo de formação, tal como se apresenta, parece "prestar-se à 
manutenção de formas burocráticas e rotineiras, nas quais impera o 'ensinar' para o 'saberfazer' e nas quais nenhum dos polos (formador e aprendiz) interage para o seu desenvolvimento profissional"( FERRO, 1998, p.160 apud RODRIGUES, 2004, p.144).

Paradoxalmente, espera-se que esse professor seja capaz de elaborar projetos, considerando aspectos tais como a escolha e a organização do que e como ensinar, além de lidar com múltiplas interferências conflitantes e classes numerosas. Aliada a um processo histórico de construção e desconstrução identitária, existe ainda a crença de que só se aprende inglês fora do país ou em escolas especializadas (RODRIGUES, 2004, p.144).

No tocante à organização do ensino de Língua Estrangeira (LE), diz a Lei de Diretrizes e Bases da Educação Nacional (LDBN), de 20 de dezembro de 1996, em seu artigo 24, inciso IV, que "poderão organizar-se classes, ou turmas, com alunos de séries distintas, com níveis equivalentes de adiantamento na matéria, para o ensino de LE, artes ou outros componentes curriculares". Seguindo essa orientação, escolas privadas firmaram convênios com institutos de língua, com a finalidade de oferecer um "bom" curso, "legitimando a impossibilidade do ensino de línguas estrangeiras na grade curricular e transformando a disciplina em um apêndice do currículo" (RODRIGUES, 2004, p.145).

Prossegue a autora, afirmando que a política e os objetivos de uma escola especializada de línguas não são os mesmos da escola regular, mostrando-nos os desafios no ensino de Língua Estrangeira, para ser imposta como disciplina fundamental no currículo do Ensino Básico, Fundamental e Médio. Uma das razões para tal status advém da falta de uma política clara, em nível nacional, o que reforça uma visão enfraquecida e secundária de sua posição no meio educacional (CELANI, 2009). As Diretrizes Curriculares para os cursos de Letras parecem ter sido aceitas pela maior parte das instituições de Ensino Superior, mas o resultado tem se mostrado na "formação deficiente de professores, em faculdades sem qualidade que se proliferam pelo país, e na escassez de programas de Educação continuada" (CELANI, 2009).

A constatação da autora é conflitante com o que esperam as Diretrizes Curriculares para o curso de Letras, de 3 de abril de 2001, como resultado do processo de aprendizagem do futuro professor de LE:

O resultado do processo de aprendizagem deverá ser a formação profissional que, além da base específica consolidada, esteja apto a atuar, interdisciplinarmente, em áreas afins. Deverá ter também a capacidade de resolver problemas, tomar decisões, trabalhar em equipe e comunicar-se dentro da multidisciplinaridade dos diversos saberes que compõem a formação universitária em Letras. O profissional de Letras deverá, ainda, estar compromissado com a ética, com a responsabilidade social e 
educacional e com as consequências de sua atuação no mundo do trabalho. Finalmente, deverá ampliar o senso crítico necessário para compreender a importância da busca permanente da educação continuada e do desenvolvimento profissional ${ }^{3}$.

Professores de inglês da rede pública iniciam sua trajetória de ensino, especialmente, a partir do sexto ano do Ensino Fundamental, quando está determinado pela Lei de Diretrizes e Bases da Educação Nacional (LDBN), de 20 de dezembro de 1996, "o ensino de uma Língua Estrangeira moderna, a cargo da comunidade escolar e dentro de suas possibilidades". Entretanto, desde a Educação Infantil, cada vez mais a oferta do ensino de Inglês tem sido incentivada, nos moldes do que já é feito no ensino privado. Amplia-se, assim, o espectro de atuação do profissional de ensino dessa Língua. No entanto, com isso ampliam-se as chances de insucesso nesse ensino.

O que os programas de Formação Continuada podem oferecer, segundo Celani (2009), é preparar o professor para enxergar e atuar como pesquisador de sua própria prática, através da reflexão. O mesmo modo de pensar transparece no depoimento de Ariadne, professora do curso de Capacitação aos alunos-professores de rede pública, da instituição binacional que acolheu esta pesquisa.

Bom, o nosso maior objetivo é que os professores tornem-se professores reflexivos e críticos da sua prática. Esse eu acredito que seja o nosso maior objetivo. Claro que, para chegar a esse maior objetivo, a essa meta, temos que passar por caminhos. No início do curso, no primeiro semestre, a gente tem um objetivo menor, que será familiarizar os professores com diferentes métodos e abordagens, teorias de aprendizagem de Língua Inglesa e também tentar fazer com que eles saiam um pouco dessa metodologia, eu diria, tradicional, que é o que a gente percebe que eles mais usam. Mas eu já estou há oito anos com um projeto com a rede pública e a gente percebe que o perfil dos professores, no início, com relação à metodologia, à abordagem do ensino da Língua para os alunos, é através do método tradicional, usando a tradução, está certo? Vendo essa visão da linguagem como um sistema de palavras de signos ou de regras gramaticais.

Na verdade, a necessidade de bons professores torna-se uma demanda crucial, frente a um fluxo de dezena de milhões de alunos. Mello (2000, p.8) demonstra preocupação com o futuro do ensino brasileiro. Diz a autora que, "no futuro, o país vai precisar de bons professores que substituam os hoje existentes". Continua, afirmando que

toda e qualquer melhoria na formação desse fluxo de mais de um milhão de professores vai representar um ensino melhor para dezenas de milhões de alunos, durante os 25 anos que durarem a carreira de cada geração de professores [...] é urgente desde já investir na organização de um sistema nacional de credenciamento de cursos e certificação de competências

\footnotetext{
${ }^{3}$ Disponível em: htpp://inforum.insite.com.br;1739;100331.html. Acesso em: 23 jun 2009.
} 
docentes, radicalmente diferente da atual processualística de autorização e reconhecimento de cursos superiores em geral, apoiar escolas avaliadas e credenciadas, com assistência técnica e financeira,condicionar o exercício do magistério à conclusão do curso em instituição credenciada e à avaliação para certificação de competências docentes (Ibid., p.8).

A autora adverte que os custos para a formação adequada do professor seriam pequenos, se

comparados aos que são necessários para arcar com o ônus do fracasso escolar, recuperação da qualidade de aprendizagem, aceleração da escolaridade e regularização do fluxo de matricula dos milhões de alunos atendidos por professores provenientes de cursos de formação de má qualidade (Ibid., p.8).

Em alguns cursos de Formação Continuada, são propostas situações em que o professor é "preparado" para viver o papel de aluno. Diz-nos Mello (Ibid., p. 9) que, nesses casos, a situação do professor é invertidamente simétrica à situação de seu exercício profissional. Essa simetria invertida entre

a situação de formação e de exercício não implica tornar as situações de aprendizagem dos cursos de formação docente mecanicamente análogas às situações de aprendizagem típicas da criança e do jovem na Educação Média (Ibid., p.11).

Em outras palavras, a autora ressalta que a formação do professor não deve ser vista como infantilizada, mas sim como um aprender que

permita apropriar-se de estruturas comuns, abstraindo as diferenças de conjuntura [...] Trata-se principalmente de reconhecer que a aprendizagem pode ser mais ou menos estruturada, mas não pode ser descontextualizada e compartimentalizada em disciplinas estanques (Ibid., p.11).

No campo da Educação, ainda podemos lembrar cursos de Formação em que o professor traz sua história de vida não somente como material de pesquisa, mas também como instrumento para projetos pessoais, em busca de orientação e reorientação. A história da vida é abordada como determinante e como parte integrante do processo de formação.

Para Ginsburg (1990 apud NÓVOA, 2000, p.335), a

profissionalização é um processo através do qual os trabalhadores melhoram seu estatuto, elevam seus rendimentos, e aumentam seu poder e autonomia. Contrariamente a essa idéia, a proletarização provoca uma degradação do estatuto, dos rendimentos, do poder, da autonomia. Faz-se útil sublinhar quatro elementos desse último processo: a separação entre a concepção e a execução, a estandardização das tarefas, a redução dos cursos necessários à aquisição de força de trabalho e a intensificação das exigências em relação à atividade laboral. 
Nóvoa (1995, p.15), ao pretender introduzir o debate sobre a formação do professor a partir de perspectiva centrada no terreno profissional, argumenta a respeito da necessidade de pensar essa formação a partir de uma reflexão sobre a profissão docente. Tal visão inclui o desenvolvimento pessoal do professor e o desenvolvimento organizacional da escola. Para o autor (Ibid., p.24), a formação tem "ignorado sistematicamente o desenvolvimento pessoal, confundindo formar e formar-se, não compreendendo que a lógica da atividade educativa nem sempre coincide com as dinâmicas próprias da formação". Para o autor, esse trabalho de formação

deve estimular uma perspectiva crítico-reflexiva que forneça aos professores os meios de um pensamento autônomo e que facilite as dinâmicas de autoformação participativa. Estar em formação implica um investimento pessoal, um trabalho livre e criativo sobre os percursos e os projetos próprios com vista à construção de uma identidade que é também uma identidade profissional (Ibid., p.25).

Para a realização dos objetivos dessa formação do professor, Nóvoa sugere “espaços interativos entre as dimensões pessoais e profissionais, permitindo aos professores apropriar-se dos seus processos de formação e dar-lhes um sentido, no quadro de suas histórias de vida". O autor enfatiza que a formação.

não se constrói por acúmulo de (de cursos, de conhecimento, ou de técnicas), mas sim através de um trabalho de reflexividade crítica sobre as práticas e de (re)construção permanente de uma identidade pessoal. Por isso, é tão importante investir na pessoa e dar um estatuto ao saber da experiência (Ibid., p.25).

Para Nóvoa (Ibid., p.26), a troca de experiências e saberes consolida

espaços de formação mútua, nos quais cada professor é chamado a desempenhar, simultaneamente, o papel de formador e de formando. $\mathrm{O}$ diálogo entre os professores é fundamental para consolidar saberes emergentes da prática profissional.

O que o autor propõe é o desenvolvimento de uma nova cultura, uma cultura dos professores. Essa cultura passa pela produção de saberes e de valores, ela dá "corpo a um exercício autônomo da profissão docente".

Nóvoa (1995, p.26) relembra a pertinência do trabalho de Schön, nessa perspectiva do desenvolvimento pessoal do professor. Ele ressalta o triplo movimento do autor: reflexão na ação sobre e depois da ação. Esses momentos de balanço retrospectivo “sobre os percursos pessoais e profissionais são momentos em que cada um produz 'sua' vida, o que, no caso dos professores, é também produzir 'sua’ profissão” (Ibid., p.26). 
Como nos diz Rodrigues (2004, p.147), “a concepção de um curso de Formação Continuada que procure abordar a complexidade envolvida no desenvolvimento de um profissional autônomo e criador de novos percursos, inserido em um paradigma integrador, encontra sua fundamentação coerente no modelo reflexivo".

A autora ainda argumenta que "um curso de Formação Continuada deve constituir um espaço que promova não só o estudo sobre preocupações e inquietações teóricas acerca da natureza da linguagem, da aprendizagem e de organização do ensino, mas também viabilize reflexões sobre sua transposição para prática docente" (Ibid., p.147).

Nessa prática, a teoria aprendida é adicionada às crenças do professor e sua história de vida. Nesse sentido, Rodrigues (Ibid., p.147) mostra ser necessária uma organização do curso de Formação Continuada que estabeleça as conexões necessárias entre um conhecimento adquirido (relativo aos conceitos, teorias e habilidades aceitas como parte do conteúdo intelectual necessário à profissão) e um conhecimento experimental (adquirido e desenvolvido em um processo de reflexão sobre e na atuação profissional), trazendo à tona modelos mais plausíveis que aproximem a teoria da prática.

\subsubsection{Modelos de formação}

Quando se pensa em formação profissional e na organização de cursos dessa natureza, as duas tendências já apresentadas neste capítulo, a estruturante e a interativoconstrutivista, são normalmente as opções a serem seguidas, isoladamente ou complementares entre si. Apesar de essas duas tendências se firmarem em visões diferentes, ambas se atêm a modelos. Obviamente, modelos diferentes de formação. Na primeira, em que se definem previamente programas, procedimentos e recursos, a partir de uma lógica de racionalidade científica e técnica aplicada ao grupo, são escolhidos modelos de formação nos quais se priorizam especialmente os conhecimentos técnicos e conceitos. No segundo caso, em contrapartida, são mais adequados modelos que atendam à investigação do contexto e dos profissionais, propiciando a reflexão sobre ambos. A seguir, serão apresentados alguns desses modelos. 


\subsubsection{O modelo de Kolb e as ampliações a esse modelo}

Kolb (1984 apud UR, 1996, p.6) elabora seu modelo de formação pedagógica baseado em um modelo experimental e define quatro estágios: a experiência concreta, a observação reflexiva, a conceituação abstrata e a experimentação ativa.

Uma experiência concreta experimentada em sala de aula deve ser seguida de uma observação em que o professor volte a refletir sobre o que ocorreu, formulando a seguir um conceito sobre o ocorrido. A experiência ativa resume-se à implementação da ideia na prática, o que acarreta outra experiência concreta. Ur (1996, p.6) acrescenta à experiência de Kolb as fontes externas, como importantes insumos a seu modelo. Para Ur, é irreal e é perda de tempo esperar que os professores-alunos reinventem a roda. Há muito a se aprender com professores experientes, como nos diz o Modelo Craft, com professores especialistas, com resultados de pesquisas das Ciências Aplicadas e com leituras. Em outras palavras, Ur propõe a integração de outras fontes de conhecimento ao ciclo reflexivo proposto por Kolb.

\subsubsection{Os modelos de Wallace}

Os Modelos de Wallace (1991, p.5-7) foram desenvolvidos a partir de sua historicidade, ou seja, para o autor, apareceram em cena, historicamente, na seguinte ordem:

O Modelo Craft, que condiciona o conhecimento de um profissional - em nosso caso, um professor - às instruções que recebeu de outro profissional com bastante experiência. O jovem profissional aprende pela imitação, seguindo instruções de como realizar certa tarefa, uma aula, por exemplo. Através desse processo, comparado à execução de uma arte artesanal, o "profissional-aprendiz" desenvolve habilidades, expertises, que são passadas de geração a geração. Esse modelo conservador corresponde a uma sociedade mais primitiva, em que o velho mestre passa aos discípulos sua arte, e hoje em dia conflita com novas metodologias e novos programas e com situações em que o professor mais jovem, muitas vezes, está mais bem informado do que o velho mestre. . No entanto, em alguns casos, o modelo é ainda utilizado para exemplificar o uso de determinadas técnicas. 
O Modelo das Ciências Aplicadas é o modelo tradicional de transmissão e o que fundamenta cursos de Capacitação, sejam de Medicina ou Arquitetura ou Educação. Esse modelo apoia-se na autoridade dos resultados das ciências empíricas, em especial dos séculos XIX e XX. Em Educação, a análise de problemas, como a indisciplina, consistiria em aplicar o conhecimento científico para atingir certos objetivos; assim, especialistas ensinariam os jovens profissionais a resolverem seus problemas em sala de aula. Por exemplo, um psicólogo daria aos professores aulas sobre Psicologia Comportamental, para que estes pudessem lidar com o problema da indisciplina em sala de aula. Caso esses ensinamentos falhassem, a razão estaria na má compreensão dos achados científicos ou em sua aplicação errônea pelos professores.

O Modelo Reflexivo corresponde à reflexão-na-ação e reflexão-sobre a-ação, como em Schön. Wallace nomeia de conhecimento recebido aquele que:

a. o indivíduo recebeu, ao invés de experimentá-lo na ação educativa;

b. faz ecoar a frase sabedoria recebida, que significa o que é comumente aceito sem provas e sem perguntas.

O conhecimento recebido de Wallace contrasta com outro tipo de conhecimento chamado experimental, derivado de dois conceitos de Schön, de conhecer-na-ação e reflexãona-ação.

Para Schön, conhecer-na-ação refere-se a tipos de conhecimentos revelados em nossa ação inteligente - performances físicas, publicamente observáveis - como andar de bicicleta -, ou operações privadas - como a análise instantânea de uma folha de balanço. Nos dois casos, o conhecimento está na ação. Nós o revelamos pela nossa execução capacitada e espontânea da performance e é uma característica nossa sermos incapazes de torná-la verbalmente explícita (SCHÖN, 2008, p.31)

Reflexão-na-ação, por sua vez, refere-se a um "pensamento retrospectivo sobre o que fizemos, de modo a descobrir como nosso ato de conhecer-na-ação pode ter contribuído para um resultado inesperado" (Ibid., p.32). "Na reflexão-na-ação, o repensar de algumas partes de nosso conhecer-na-ação leva a experimentos imediatos e a mais pensamentos que afetam o que fazemos - na situação em questão e talvez em outras que possamos considerar semelhante a ela" (Ibid., p.34). Ao responder questões que surgem na reflexão-na-ação, temos o caminho para o possível autodesenvolvimento, completa Wallace (op.cit.,p.14).

Ur (1996, p.5) indaga qual desses modelos de formação seria o mais eficiente. Em outras palavras, a autora formula a questão de como os professores aprendem melhor e como 
esse aprendizado pode ser integrado ao seu programa de formação. Ur, por várias vezes, perguntou a grupos de professores, em diversos países, como e de que fonte eles aprenderam suas habilidades didáticas e conhecimento. Várias fontes foram sugeridas, como os próprios colegas, professores-mestres, a literatura, cursos de Formação, suas próprias experiências como aprendizes. Ao fazerem uma avaliação dessas fontes, revelou-se que a experiência pessoal foi vista como a mais importante entre todas elas. A autora (Ibid., p.6) concorda que, embora tenha estudado e lido materiais diversos e comparecido a cursos e conferências, ela mesma responderia, como os demais professores, que aprendeu principalmente pensando em sua própria experiência em sala de aula. O que não significa que as outras fontes de conhecimento e aprendizado não tenham contribuído, mas significa que elas são, provavelmente, menos importantes.

Os cursos de Formação baseados no Modelo Reflexivo, diz UR (Ibid., p.6), têm como função processar todo o input recebido de todas as fontes, de modo que o conhecimento torne-se pessoalmente significativo para o professor-aluno. Portanto, um modelo reflexivo completamente efetivo deveria abrir espaço para o conhecimento externo e o pessoal.

\subsubsection{A noção de competência}

Nóvoa (2009) valoriza duas competências. A primeira é uma competência de organização. O autor pensa que hoje o professor não é somente um transmissor de conhecimento e também não é alguém que só trabalha dentro de uma sala de aula.

O professor é um organizador de aprendizagens, de aprendizagem via os novos meios informáticos, por meio dessas novas realidades virtuais. Organizador do ponto de vista da organização da escola, do ponto de vista de uma organização mais ampla, que é a organização da turma ou da sala de aula.

Segundo Aquino Groppa (1998, p.15), o contrato pedagógico precisa ter suas regras explicitadas "para todos os envolvidos, conhecidas e compartilhadas por aqueles inseridos no jogo escolar, mesmo se elas tiverem de ser lembradas (ou até mesmo transformadas) todos os dias". O autor sugere que jamais se inicie um curso ou um ano letivo "sem que as regras de funcionamento dessa "sala de aula", "laboratório" sejam conhecidas, partilhadas e, se possível, negociadas por todos”. 
Encontramos, também, em Apple (1995), que escreveu seu próprio diário como professor, a importância desse contrato pedagógico, cuja ausência em sala transforma a aula em um ritual vazio.

Apple, J. (1995, p.xiii) diz:

Educational questions, especially the relationship between students and teachers, are foundations for the teaching of any subject. Language teaching at school must therefore be considered in conjunction with them. If personal relations in the classroom are not healthy, teaching quickly becomes an empty ritual because there is no chance of it being effective in classes that are unruly, apathetic or hostile. Conversely every method or piece of material a teacher uses has an educational impact. A change of seating arrangements means more than just changing the positions of chairs and tables. Teaching school children is more than the attainment of language objectives. I was often under the impression that language instruction in the school classroom was merely the stage on which the actual drama of education took place. One outcome of this drama has been described by the term 'hidden curriculum'.

Questões educacionais, especialmente o relacionamento entre alunos e professores, são fundamentos do ensino de qualquer matéria. $\mathrm{O}$ ensino de Língua, na escola, deve, portanto, ser considerado em conjunto com elas. Se as relações pessoais na sala de aula não forem saudáveis, o ensino rapidamente se transforma em um ritual vazio, pois não há nenhuma chance de ser efetivo em classes que são barulhentas, apáticas ou hostis. Contrariamente, cada método ou material que um professor usa tem um impacto educacional. Uma mudança de lugar em que os alunos estão sentados significa mais do que mudar somente a posição das cadeiras e mesas. Lecionar para crianças vai além do objetivo linguístico. Tive sempre a impressão de que a instrução na aula de LE era simplesmente um estágio no qual o drama real da Educação instalava-se. Um resultado desse drama foi descrito pelo termo currículo oculto. (tradução nossa)

O contrato pedagógico também salienta o respeito pela autoridade do professor, mas não o respeito nos moldes militares. No dizer de AQUINO GROPPA (1998, p.5 ), "hoje, o professor não é mais um encarregado de distribuir e fazer cumprir ordens disciplinares, mas um profissional cujas tarefas nem sequer se aproximam dessa função disciplinadora, apassivadora, silenciadora, de antes."

O bom aluno, para o autor, não é o calado, imóvel, obediente ou, como encontramos nos registros, copistas.

Expulsões, ameaças, "transferências" são estratégias, marcadas nos depoimentos dos professores, remanescentes da escola do passado, que não têm lugar em uma escola da contemporaneidade. Há, nos registros dos participantes desta pesquisa, inúmeros relatos de ações disciplinadoras - tais como mandar para fora da sala, copiar da lousa, esperar aquietarem-se - que mostram a necessidade de novas concepções a respeito do ofício do 
professor e do papel do aluno em nossos dias. Aquino Groppa (1998, p.15) propõe que se olhe diferentemente para o problema da indisciplina e sugere vê-la como um indício "de que a intervenção docente não está se processando a contento, que seus resultados não se aproximam do esperado". Para o autor, nunca devemos nos esquecer de que é dever do professor ensinar e é direito do aluno aprender (op.cit.p.14).

Há aqui, portanto, o que ele designa de organização do trabalho escolar e

esta organização do trabalho escolar é mais do que o simples trabalho pedagógico, é mais do que o simples trabalho de ensino, é qualquer coisa que vai além dessas dimensões, e estas competências de organização são essenciais para um professor (NOVOA, 2009).

Nóvoa (Ibid., p.1) afirma a importância de um segundo nível de competências relacionadas à compreensão do conhecimento. Diz o autor que "não basta deter o conhecimento, para o saber transmitir a alguém, é preciso compreender o conhecimento, ser capaz de reorganizá-lo, ser capaz de reelaborá-lo e de transpô-lo em situação didática em sala de aula". O autor explica a função dupla do professor: organizador do trabalho escolar e detentor de um determinado conhecimento, capaz de reelaborá-lo, no sentido de sua capacidade de ensinar (Ibid., p.2).

É obrigatório que não abramos mão, sob hipótese alguma, do escopo de nossa ação, do objeto de nosso trabalho, que é apenas um: o conhecimento. É imprescindível que tenhamos clareza de nossa tarefa em sala de aula, para que o aluno possa ter clareza também da dele. A visibilidade do aluno quanto ao seu papel é diretamente proporcional à do professor. A ação do aluno é, de certa forma, o espelho da ação do professor. Portanto se há fracasso, o fracasso "é de todos; e o mesmo em relação ao sucesso escolar" (AQUINO GROPPA, J.1998, p.15).

Para Morin (2009, p.1), o conhecimento é o primeiro buraco negro fragmentado e subestimado no programa educativo. Para o autor, nunca se ensina de fato o que é conhecimento, pois o conhecimento não é um reflexo da realidade, é sempre uma tradução, seguida de uma reconstrução. As crenças do passado, para Morin, contêm erros e ilusões, havendo também erros históricos, diferenças culturais e sociais. Cada um pensa que suas ideias são as mais evidentes e esse pensamento leva a ideias normativas - as que não são consideradas normais são taxadas como ridículas. Afirma o autor que

portanto, o problema do conhecimento não deve ser um problema restrito aos filósofos, é um problema de todos e cada um deve levá-lo em conta desde muito cedo e explorar as possibilidades de erro, para ter condições de ver a realidade, porque não existe receita milagrosa (Ibid., p.4). 
Gadotti (2008, p.55) também nos lembra que a sociedade contemporânea está marcada pela questão do conhecimento. Mas essa vem a ser uma fala sem propriedade, pois "mais do que a era do conhecimento, devemos dizer que vivemos a era da informação, pois percebemos com mais facilidade a disseminação de informação e de dados do que a de conhecimentos". Diz o autor que o acesso ao conhecimento ainda é precário, em sociedades com grande atraso educacional. E ele faz, então, duas indagações: O que é conhecer? Como conhecer?

"Conhecer é construir categorias de pensamento", ou seja, reconstruir o conhecimento. Já, como resposta para a segunda questão, Gadotti afirma que só é possível conhecer, quando se deseja, quando se quer, "quando nos envolvemos profundamente com o que aprendemos" (GADOTTI, 2008, p.56).

Machado (2009, p.26) aponta outro passo importante para se atingir um resultado educativo e trabalha, também, o conceito de competência. Para o autor, o saber, por si só, não garante atingir objetivos educacionais; é necessário mobilizar os recursos obtidos, e a essa mobilização ele denomina competência. Diz Machado que: "Não basta desejar, não basta conhecer, "é preciso competência para realizar" (Ibid., p.26). E (2009) define o conceito de competência através de seus elementos constitutivos.

O primeiro vem a ser a pessoalidade, ou seja, as pessoas é que são ou não são competentes. Não podemos atribuir competência a um computador ou a objetos. $\mathrm{Na}$ visão de Machado (2009, p.28),

elaborar uma lista exaustiva de competências pessoais é uma tarefa impossível, além de ser, sobretudo, carente de sentido. A questão efetivamente significativa é a construção de uma lista de competências básicas, características do modo de ser do ser humano, a partir das quais todas as competências específicas possam ser referidas.

E refere-se também ao contexto no qual a competência materializa-se:

Quanto mais restrito é o âmbito em que uma competência se exerce, mais facilmente ela pode ser caracterizada em seus pormenores, estruturada em habilidades capilares que lhe dão forma e consistência, quanto mais amplo é o âmbito, mais difícil é tal estruturação, sempre necessária (Ibid., p.31).

No âmbito do ensino de LES (Línguas Estrangeiras), as competências necessárias ao exercício do professor parecem não ser muito claras aos professores que deram depoimentos a esta pesquisa. Consequentemente, a mobilização de saberes, como a capacidade de se expressar em LE, fica comprometida com essa falta de conhecimento sobre como mobilizar o saber linguístico através de uma dada metodologia. 
A mobilização também vem a ser o outro elemento constitutivo da noção de competência, na visão de Machado (2009, p.33):

as competências constituem padrões de articulação do conhecimento a serviço da inteligência, entendida aqui como a capacidade de projetar, de alimentar projetos em um cenário de valores socialmente acordados. Elas podem ser associadas aos esquemas de ação desde os mais simples até as formas mais elaboradas de mobilização do conhecimento, como a capacidade de expressar-se em diferentes linguagens, de argumentar para defender um ponto de vista, de tomar decisões, de enfrentar situaçõesproblema, entre outras (Ibid., p.33).

O primeiro par a ser estudado é o da pessoalidade-integridade, que pressupõe a integração com os outros.

Além do quadro de valores e da sintonia entre o discurso e a ação, a integridade pressupõe uma permanente disponibilidade para interação com outras pessoas, com quadros de valores distintos do nosso. A integridade está associada de modo essencial a uma abertura no quadro de valores para o diálogo, para a argumentação racional em busca de consensos, sendo factíveis tanto o convencimento do outro quanto à aceitação de sua perspectiva (Ibid., p.39).

$\mathrm{O}$ autor distingue uma competência articulada à integridade de uma competência somente técnica, sem saber o que faz e para quem faz. A competência "não pode limitar-se à dimensão técnica, ela sempre está associada a uma ação envolvendo valores” (Ibid., p.40).

O próximo par constitui-se em um eixo fundamental para a construção da ideia de competência e congrega dois valores: mobilização e conteúdo. Para Machado (2009, p.41), “especialmente competente é quem sabe combinar de modo eficaz a busca pelo conhecimento de que se necessita com as formas adequadas de mobilização do mesmo.”

Finalmente, Machado destaca a parceria âmbito-extrapolação, em que se desenvolve a capacidade de abstrair o contexto da ação e extrapolá-lo para situações novas, para situações imaginadas, que poderão vir a ser ou acontecer.

\subsubsection{Modelos de aprendizagem}

Diz Perrenoud (2000) que, por muito tempo, o ofício do professor resumia-se ao Modelo Craft, qual seja a figura do Magister, dirigindo-se a centenas de discípulos que bebiam de suas palavras Seria essa uma situação em que o foco da aula residiria no mestre, o modelo de ensino teria como centro o professor, de cujas palavras emanam poder e 
conhecimento. Esse modelo prevaleceu por um século e era destinado aos herdeiros "aqueles que dispõem dos meios culturais para tirar proveito de uma situação, de uma formação que se dirige formalmente a todos, na ilusão da equidade [...]” (PERRENOUD, 2000, p.24). Já, dentro de um modelo em que o principal personagem é o próprio aluno, o professor não mais se situa no centro, mas pode desenvolver a competência de dominar a situação; para Perrenoud, tal competência designa a capacidade de mobilização de recursos cognitivos, a fim de enfrentar um tipo de situação. Três elementos são cruciais para se organizar e dirigir situações de aprendizagem: (1) a situação; (2) os recursos teórico-metodológicos; (3) as operações mentais que permitam mobilizar os recursos.

Dentro dessa nova posição do educador, os alunos não vão à aula com o intuito de ouvir o mestre e operacionalizar regras para determinado exercício. Essas atividades podem ter uma aplicação didática, mas não são o começo e o fim do trabalho em sala de aula.

Perrenoud (2000, p.26) desenvolve o conceito de organizar situações, propondo a tradução dos conteúdos em objetivos de aprendizagem, objetivos estes a serem perseguidos não de maneira mecânica. $\mathrm{O}$ autor propõe a identificação das competências-chave, ao redor das quais o trabalho em sala pode ser estruturado. Em uma aula de Inglês, o aluno, por exemplo, não deve decorar o verbo to be simplesmente. No entanto, o professor deve propor contextos de ensino e recursos teórico-metodológicos que podem levá-lo, por exemplo, ao uso do verbo em situações reais de apresentação: Hello! I am Maria and here is my friend Francisco. Nice to meet you.

Outro aspecto importante nas situações de aprendizagem tem relação com o trabalho a partir das representações dos alunos. Essa competência significa dar aos alunos o direito de expressarem suas ideias, conceitos e valores, para que dessas representações possa advir novo conhecimento. Essa ideia é particularmente válida em aulas de Inglês, em que os alunos podem nunca ter tido conhecimento de certos traços culturais de países falantes da LE. Falar sobre neve, trenó, festas folclóricas, por exemplo, abre espaço para novas aprendizagens e até para um confronto com eventuais representações já existentes.

Outras competências-chave, descritas a seguir, também auxiliam o professor no encaminhamento das situações de aprendizagem. 


\subsubsection{Trabalhar a partir dos erros e dos obstáculos à aprendizagem}

O princípio norteador dessa competência é antagônico à ideia de memorização e identifica-se com a ideia de reestruturação de seu sistema, de compreensão do mundo, de restabelecimento de equilíbrio. Para o autor (2000, p.32), o professor deve se interessar pelos erros dos alunos e aceitá-los como etapas estimáveis do esforço em compreender. Ele sugere que o professor não corrija os erros do aluno de Inglês, mas leve-o a buscar esses erros em sentenças, como se fosse um jogo em que, na verdade, esse aluno estivesse identificando diferenças entre duas línguas distintas. Leva um tempo relativo para o aluno iniciante perceber que, em inglês, usa-se o verbo ser em I am 20 years old, e não o verbo ter, como em português, e então há frequentes repetições de I have 20 years old.

\subsubsection{Construir e planejar dispositivos e sequências didáticas}

Essa competência leva à mobilização do aluno para criar, descobrir o que fazer em determinadas situações. Podemos supor uma situação em que os alunos, em grupos, deverão entrevistar um cientista ou um político. Para tal, devem elaborar em inglês as questões da entrevista, decidindo também quem será o entrevistado. Os alunos deverão pensar quais perguntas são mais apropriadas ao entrevistado, a partir das informações que têm em mente obter. Na sequência, eles devem representar a situação em classe, dramatizando a entrevista. Os alunos estarão envolvidos com o saber, a ação, a cooperação, o obstáculo, o tempo, o êxito.

\subsubsection{Envolver os alunos em atividades de pesquisa, em projetos de conhecimento}

Um projeto de conhecimento, na visão de Perrenoud, vem ancorado a uma cumplicidade e uma solidariedade na busca de tal conhecimento. Há nessa concepção uma relação com a pesquisa, pois se exige capacidade de organização e de solução de problemas. 
Em uma aula de Inglês, há grande variedade de projetos possíveis, pois conhecer outra Língua é conhecer outro mundo, com costumes diferentes e maneiras singulares de atribuição de valores. Dessa forma, o professor pode ser o grande motivador para uma equipe que deseja conhecer países falantes da língua inglesa, como a Nova Zelândia, Austrália, Estados Unidos, Inglaterra, Canadá. Países diversos podem abrir diversos campos do saber a serem pesquisados. Perrenoud menciona questões - problemas a serem enfrentadas nesses projetos -, muitas delas envolvendo diferenças culturais.

A importância que um aluno dá ao aprendizado da língua inglesa e a seu uso é o estímulo que ele terá em seu desejo de saber. Diz-nos Perrenoud (2000, p.71): “só se pode desejar saber ler, calcular de cabeça, falar alemão ou compreender o ciclo da água, quando se concebem esses conhecimentos e seus usos".

\subsubsection{Estabelecer laços com as teorias subjacentes às atividades de aprendizagem}

Perrenoud (2000, p.48) propõe a competência que permite ao professor escolher e modular as atividades de aprendizagem. Em outras palavras, ele acredita que simplesmente qualquer atividade feita "por falta de algo melhor" ou "como de hábito" deve ser substituída por uma escolha consciente e criativa, que permita aos alunos explorar possibilidades de utilização dos saberes e que estes funcionem como recursos para a efetiva aprendizagem. Nesse sentido, espera-se pleno envolvimento dos alunos na atividade; um envolvimento que vá além do "copie e traduza".

\subsubsection{Observar e avaliar os alunos em situações de aprendizagem, de acordo com uma abordagem formativa}

Um portfólio e um diário são os instrumentos propostos por Perrenoud para avaliar os alunos. A observação contínua tem seu objetivo formativo, ou seja, considera-se tudo o que pode auxiliar o aluno a aprender melhor. Em aulas de Inglês, o próprio aluno, muitas vezes, sabe o que quer: "Quero conversação" é o pedido mais comum. "Quero 
entender certas músicas”. Professores experientes e lúcidos, na opinião de Perrenoud, são capazes de detectar

a. alunos que têm pequenas chances de aprender, porque a tarefa exige demais, porque não se envolvem, entendiam-se, trabalham com lentidão, copiam dos colegas, não têm objetivos, fixam-se em detalhes, agitam-se para responder, esperando que se passe a outro ponto;

b. alunos com boas chances de aprender, porque se envolvem, interessam-se, expressam-se, engajam-se na tarefa, cooperam, parecem divertir-se, fazem perguntas e questionam-se (Ibid., p.50).

Perrenoud (Ibid., p.50) chama a atenção para alguns aspectos na hora da avaliação. Diz o autor que é preciso descobrir as artimanhas daqueles alunos que, geralmente, são mestres na arte de parecerem ativos, mas também é preciso saber que o silêncio não é garantia de aprendizagem. $\mathrm{Na}$ verdade, ele acredita que os alunos que conversam em aula aprendem melhor do que aqueles considerados modelos. Um trabalho de formação ajudaria os professores a determinarem os indicadores de aprendizagem que permitem uma regulação interativa. Perrenoud menciona o que ele próprio denomina de perspectiva pragmática, que é a relação diária com o aluno e sua intuição. $\mathrm{O}$ autor ainda sugere algumas linhas de ação tais como:

a. aposta em tecnologias e dispositivos didáticos interativos;

b. avaliação mútua;

c. desenvolvimento de uma avaliação formadora. O aluno dá provas de que aprendeu de forma lúcida;

d. favorecimento da metacognição como fonte de autorregulação dos processos de aprendizagem;

e. identificação de um todo, a partir de várias observações que guiarão sua ação e suas prioridades;

f. integração da avaliação contínua e didática;

g. não separação de avaliação e ensino, considerando cada situação de aprendizagem como fonte de informação (Ibid., p.51). 


\subsubsection{Fazer balanços periódicos de competências e tomar decisões de progressão}

Parte das competências básicas do professor encontra-se na decisão sobre o progresso do aluno. Não é fácil responder a pergunta: em que grupo determinado aluno teria mais chance de progredir? Faz-se necessário um balanço das aquisições e, ao mesmo tempo, um prognóstico que considere todos os recursos disponíveis.

\subsubsection{Participar da administração da escola}

Estamos nos referindo em especial à competência em organizar e fazer evoluir, no âmbito da escola, a participação dos alunos. Para Perrenoud (2000, p.106), a participação dos alunos é uma forma de educação para a cidadania.

Em uma entrevista oral, observamos um professor que nos mostra uma forma de otimismo e respeito à capacidade de seus alunos para exercerem responsabilidade e enfrentarem problemas da comunidade em que vivem, através da sua participação no grêmio da escola.

\section{Professora Mariana}

Trabalho como professora há 8 anos. Atualmente trabalho em 4 escolas no mesmo bairro onde moro, Guaianazes. Até o ano passado, as escolas eram bem próximas da minha casa, isso facilitava o trabalho com a comunidade. Este ano estou trabalhando um pouco distante, a 20 minutos da minha casa, na cidade Tiradentes; uma escola enorme e muito bem organizada [...] O que eu mais gosto lá são os coordenadores, são pessoas politizadas e se preocupam com a função da escola na comunidade e com o verdadeiro sentido da Educação.

Gosto de trabalhar com formação de grêmio na escola, porque o grêmio faz surgir lideranças, faz com que o aluno goste da escola e transforma o aluno em protagonista do seu tempo. Vejo as escolas da periferia não apenas como um lugar de transmissão do conhecimento formal, mas como um espaço de convivência significativo, onde são depositadas todas as esperanças de transformação e mudança de vida.

Não daremos conta de nos aprofundar em todas as competências sugeridas por Perrenoud, mas seria relevante atermo-nos, também, àquela que toca diretamente o ofício do professor e que tem grande relevância para nosso tema. 


\subsubsection{Administrar sua própria Formação Contínua}

Saber administrar sua própria formação contínua é saber administrar os recursos cognitivos mobilizados pelas competências que devem ser atualizados, adaptados a condições de trabalho em evolução (PERRENOUD, 2000, p.156). Diz o autor: “ O exercício e o treino poderiam bastar para manter competências essenciais, se a escola fosse um mundo estável. Ora, exerce-se o ofício em contextos inéditos, diante de públicos que mudam, em referência a programas repensados, supostamente baseados em novos conhecimentos, até mesmo em novas abordagens e novos paradigmas". Ainda para o autor (op.cit, p.158), a formação contínua acompanha transformações identitárias e o primeiro sinal disso é sua própria institucionalização, recente e frágil. Cinco componentes principais são formadores dessa competência:

1. saber explicitar as próprias práticas;

2. estabelecer seu próprio balanço de competências e seu programa de formação continua;

3. negociar com os colegas um projeto de formação comum (equipe, escola, rede);

4. envolver-se em tarefas, em escala de uma ordem de ensino ou do sistema educativo;

5. acolher a formação do colega e participar dela (PERRENOUD, 2000, p.158).

\subsection{A FORMAÇÃO CONTINUADA DOS PROFESSORES DA REDE PÚBLICA}

\subsubsection{A formação continuada de professores de inglês}

Procuramos por cursos de Formação Continuada para professores de inglês e encontramos poucas opções. O primeiro foi o da instituição que promove o curso em foco nesta tese. O público alvo é mencionado (professores de Língua Inglesa, em regência no Ensino Fundamental II e na Rede Municipal de Ensino). A instituição que oferece o curso e a Secretaria Municipal de Educação mantêm convênio para a oferta de um curso de Capacitação 
de 1 (um) ano. São também indicados o local do curso, a carga horária (180 horas-aula, sendo 162 horas-aula presenciais e 18 horas-aula náo presenciais, destinadas a estudo e desenvolvimento de um projeto pedagógico, nas respectivas unidades escolares). $\mathrm{O}$ cronograma explicita todos os dados necessários: como fazer a inscrição, o tipo de avaliação, os certificados e a organização geral do curso. Além deste, digitamos APLIESP, a Associação dos Porfessores de Inglês do Estado de São Paulo, a fim de verificarmos outas opções de cursos. A Associação prevê a ocorrência de eventos com o intuito de "oferecer possibilidades de crescimento acadêmico e profissional aos professores de Língua Inglesa, graduandos, entre outros profissionais da área"4.

A entidade promove anualmente dois eventos: a JELI (Jornada de Ensino da Língua Inglesa), com duração de dois dias, geralmente em maio, e a SPRING CONFERENCE, entre setembro e outubro, com duração de um dia. Mais dois eventos foram criados, no entanto: a APLIESP REGIONAL CONFERENCE, encontro de um dia, gratuito para os associados, e a APLIESP ON LINE CONFERENCE.

Em suma, observamos que, embora instituídos por lei, como já citado, os cursos de Formação Continuada para professores de Inglês são ainda escassos - além disso, no caso dos cursos da Apliesp, somente o professor cadastrado como membro não precisa pagar. A questão do pagamento faz questionar se há sentido em cobrar do professor ou ainda em fazêlo pagar para ir ao encontro desses cursos e exercer seu ofício com melhores resultados. Em muitos países, treinamentos para futuro ofício são remunerados. Levando-se em conta a remuneração dos professores da rede pública, além das dificuldades em disporem dos valores previstos para o pagamento de cursos dessa natureza, há também a dificuldade em disporem de tempo em suas agendas e tempo para se locomoverem de lugares distantes para o local em que os cursos ocorrem.

Uma vez que se enfatiza na lei a necessidade de formação continuada, constatamos ainda que os incentivos são bastante pequenos. Surge, daí um conflito entre o desejo de aprimoramento do professor e as possibilidades, condições de participar. Os professores que conseguem alcançar esse intuito, certamente, são aqueles que realmente querem exercer seu papel com eficiência e dedicação, caso específico dos professores que participaram desta pesquisa. . Portanto, frente a um dispositivo legal que praticamente institui a "obrigatoriedade dos cursos de Formação Continuada" o conflito entre o desejo e as oportunidades para essa formação cria um quadro de incoerência e descompasso. Em busca

\footnotetext{
${ }^{4}$ Disponível em: www.apliesp.org.br. Acesso em: 11 jan 2010.
} 
desse aprimoramento, os professores de Inglês, por vezes, inscrevem-se como alunos em escolas particulares de línguas, esperando, com esse investimento, resolver seu maior problema: melhorar conhecimentos linguísticos, para ser considerado um bom professor. Essa lacuna faz-nos refletir sobre a representação do ensino da Língua Inglesa em nossas escolas públicas. Indagamos se a ideia do aprendizado de uma língua considerada de tão grande valor no mundo da ciência e dos negócios pode ainda estar subestimada para os alunos da rede, favorecendo dessa forma o vão, muitas vezes denominado fosso, entre ensino público e ensino privado de qualidade.

\subsubsection{Um espaço de formação do professor de Inglês: $O$ curso de Formação Continuada analisado nesta tese}

Nesse sentido, o curso de Formação Continuada para os professores de Inglês da rede pública, analisado nesta tese, permitiu-lhes mostrar como lecionam e levou-os a pensar novos modos de desenvolver nos alunos habilidades da língua inglesa: a escrita, a fala, a compreensão oral, a leitura. Aprenderam, também, que um texto oral ou escrito deve ser preparado para a aula, tendo o lesson plan (planejamento de aula) um lugar de destaque no curso de Formação Continuada, por facilitar o desenvolvimento da aula. Aliás, há registro da professora Melissa, mencionando que passou a manter a atenção dos alunos interessados, pelo menos por algum tempo, com aulas bem preparadas.

Teoricamente, os professores-alunos aprenderam que há três fases importantes, ao iniciar-se o ensino de uma lição: o momento pré, ou anterior; o while, ou durante, e o momento depois, denominado post. A primeira fase cuida da preparação do cenário em que a lição vai ser desenvolvida: se o assunto for, por exemplo, personalidades, os professoresalunos podem (e devem) conversar, desenhar, dramatizar o tema, a ponto de descobrirem novas palavras, expressões, em especial adjetivos, que descrevam amigos, familiares, celebridades. O momento while apresenta o texto per si - um diálogo ou prosa: é o momento da leitura de um texto que, provavelmente, conterá palavras aprendidas na fase anterior. Finalmente, o post é o momento da prática: agora é você - aluno - quem faz, fala ou faz as atividades pedidas. Ao longo do curso, foram propostas aplicações reais desse conhecimento 
teórico para as classes em que os professores lecionam. Discussões a respeito das fases e das aplicações feitas pelos professores com os seus grupos também fizeram parte do curso.

Dessa maneira, a partir do conhecimento teórico trabalhado ao longo do curso, alia-se ao aprendizado da LE um aprendizado de mundo, pois a fase pré da aula significa o acesso a um conhecimento anterior, que irá colaborar no entendimento de uma leitura, de uma música, enfim, de um texto qualquer.

No final do curso, os professores começaram a escrever planos detalhados e apresentaram aulas excepcionais, com recursos audiovisuais e desenvolvidas de acordo com o que aprenderam, ficando seguros de si e orgulhosos do que conseguiram.

O curso de Formação, nas duas vertentes trabalhadas - a da capacitação linguística e a da capacitação metodológica - aponta, portanto, na direção do conhecimento da língua e da reflexão sobre as teorias e as práticas em sala de aula, como uma das premissas fundamentais para o seu funcionamento, como podemos visualizar no quadro 2 , abaixo:

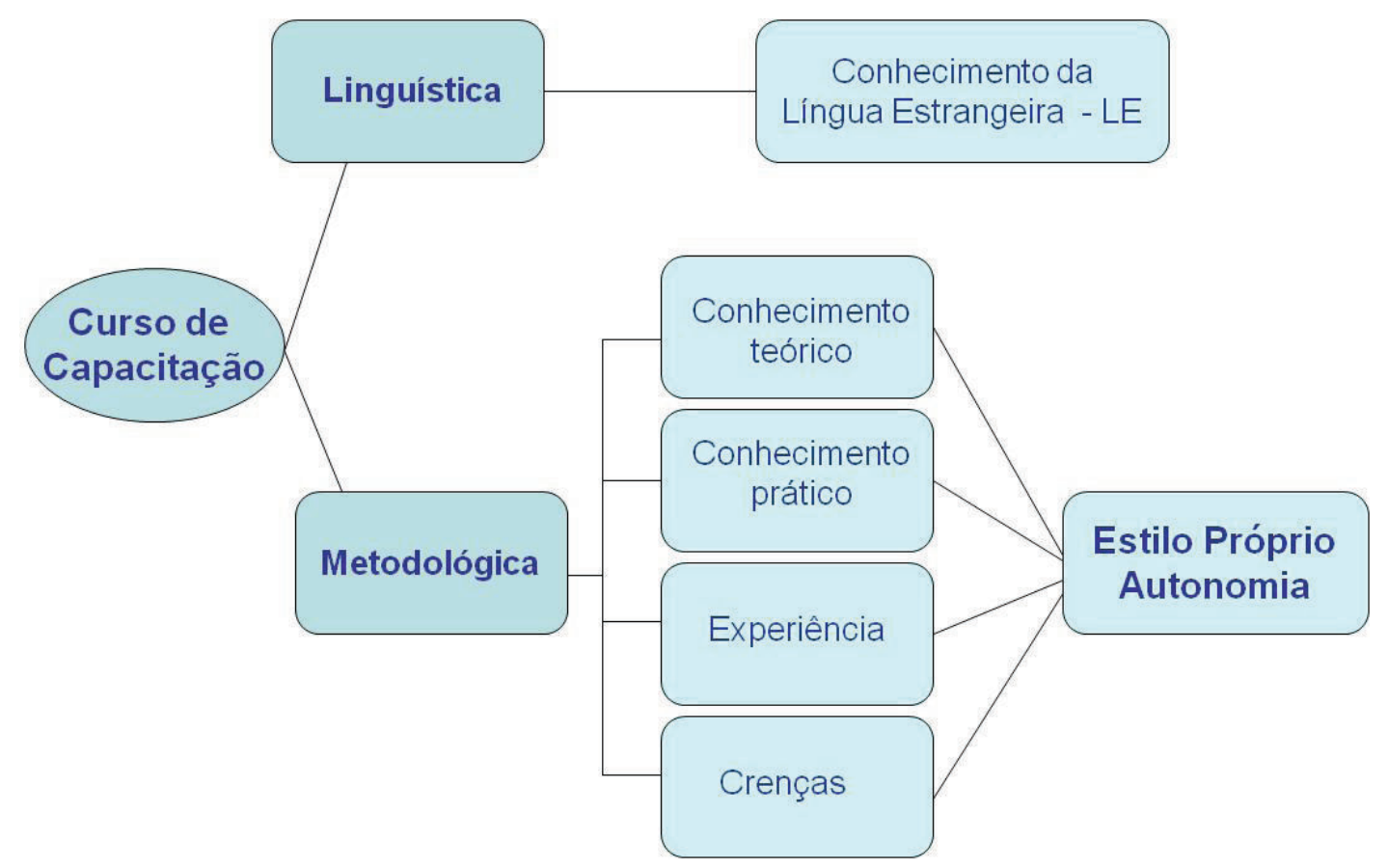

Quadro 1: Formação continuada do professor.

Apesar de nossa pesquisa ter se concentrado na observação do curso de Capacitação Metodológica, a capacitação linguística do professor não deve ser descartada como "fonte para a reflexão", constituindo-se também em "momentos de aprender e de ensinar a aprendizagem". Esse aspecto do aprendizado linguístico do curso está a cargo de professores da instituição, bastante experientes e conhecedores da língua, que lecionam a LE 
conforme o nível (medido por testes) dos professores-alunos. Esses momentos de ensinar a aprendizagem, tanto no curso de Capacitação Linguística como no de Capacitação Metodológica, que Mozart Neves Ramos (2006) chama de educação sustentável, ${ }^{5}$ devem ser aqui salientados como de grande importância no processo de formação continuada em questão, pois "são os que, bem administrados, favorecem a correlação entre teorias e práticas que dão suporte à reflexão e à busca de um desempenho profissional responsável.

\footnotetext{
${ }^{5}$ Para Ramos, N.M. (2006, p.21) os valores que compõem a educação sustentável inserem-se nos seguintes aspectos:1. oferta de uma educação básica para todos, sem um largo distanciamento entre seu PIB e seu IDH; 2.boa gestão escolar; 3. uma escola democrática e autônoma; 4.projetos escolares inovadores; 5.implantação de projetos que promovam a qualidade de vida de professores, alunos e funcionários, estendida a seus familiares, como estratégia cada vez mais adotada para melhorar o rendimento escolar.
} 


\section{CAPÍTULO 2 - A PESQUISA}

É fácil falar, quando você não está na sala de aula; ninguém imagina a bagunça que é.

Professora Melissa

Neste capítulo abordaremos teorias que fundamentam a metodologia de pesquisa, a fim de elucidarmos que procedimentos são mais adequados para as análises do material coletado. Esses procedimentos, escolhidos de acordo com os objetivos, fundamentam-se na Etnografia, para a observação das aulas do curso de Capacitação Metodológica. Selecionamos o Estudo de Caso como o caminho para levar a cabo a análise dos diários.

\subsection{O PORQUÊ DA PESQUISA E SUA ORIENTAÇÃO}

O foco desta pesquisa situa-se no campo da investigação sobre a formação continuada do professor de Língua Estrangeira (Inglês) que atua no ensino público, e formulamos as seguintes indagações, a fim de nos orientarmos em direção a:

1. Como são capacitados os professores de LE da rede pública, nos cursos de Formação Continuada? Como são organizados os cursos? Qual a sua orientação?

2. Ao participarem desses cursos, os professores estão realmente interessados em pensar sobre a sua prática? Em que momento da carreira os professores optam por cursos dessa natureza?

3. Havendo a expectativa de novas abordagens e processos de reflexão nesses cursos, há realmente alguma alteração representativa de mudanças na prática docente desses professores? Em caso positivo, no decorrer do curso, quais são as mudanças detectadas?

Inicialmente, nosso interesse era acompanhar as aulas de professores que estivessem participando de algum curso de Formação Continuada. No entanto, antes que pudéssemos organizar um projeto de pesquisa dessa natureza, tivemos ciência de um curso de Capacitação para professores de Inglês da rede municipal e estadual de São Paulo, oferecido há mais de uma década por instituição binacional, localizada na cidade de São Paulo. Além de 
trabalhar a complementação da formação pedagógica do professor, esse curso visa também a seu aperfeiçoamento linguístico na LE. Com isso, institui-se uma "mão dupla" complementar de formação, que apresenta para os professores-alunos resultados positivos, já constatados pelas Diretorias de Ensino.

Durante o curso de Metodologia, os professores-alunos devem desenvolver projeto de intervenção nas suas escolas, com apresentação de trabalho diferenciado, desenvolvido com seus alunos, com base nos conhecimentos adquiridos e práticas discutidas nas aulas.

Nasceu, então, nosso interesse em pesquisar o que acontecia no curso. As observações poderiam esclarecer, pelo menos, parte das indagações para a formulação da pesquisa para o Doutorado. Desse modo, buscamos contato com os responsáveis, para saber se haveria a possibilidade de um acompanhamento durante o ano de 2008.

O objetivo da pesquisa foi mapear mudanças na prática de ensino de LE em escolas públicas, sublinhando nelas o desenvolvimento de uma postura reflexiva que poderia ocorrer no curso de Capacitação Pedagógica.

A descoberta de uma abordagem nova de ensino, bem como de uma visão comunicativa de língua, seria investigada nos registros presentes nos diários reflexivos desses professores, à medida que frequentassem o curso de Capacitação.

Partimos do pressuposto de que haveria mudanças enquanto o professor comparecesse ao curso e, concomitantemente, refletisse a respeito de sua prática, durante a escritura de seus diários. Acreditamos que essa mudança ocorreria à medida que a prática reflexiva se instaurasse e, consequentemente, levasse o professor a agir de modo diferente.

O curso dividia-se em duas partes: Capacitação Metodológica e Capacitação Linguística. Optamos por observar aquela destinada à capacitação metodológica do professoraluno, na qual são trabalhadas propostas que visam à apresentação de diferentes abordagens de ensino e à apresentação das novas práticas aprendidas ou repensadas.

Para a delimitação da pesquisa, tendo em vista o contexto particular da capacitação em Metodologia, parte do curso de Formação Continuada, as questões de pesquisa anteriormente formuladas levaram-nos a delinear os procedimentos de coleta de dados, a partir de duas linhas metodológicas. A primeira, de cunho etnográfico, procurou dar conta das observações coletadas nas aulas, e o acompanhamento do curso deu-se ao longo dos dois semestres de 2008. A segunda, mais interpretativa, foi pensada segundo parâmetros de Estudo de Caso, a fim de estudarmos nesses sujeitos as mudanças de concepções construídas sobre a prática desse sujeito, no decorrer do curso de Capacitação. Adotamos, portanto, 
diversas frentes de coleta de dados que envolveram os seguintes procedimentos: leitura e análise dos diários escritos pelos professores, observações das aulas de Metodologia e entrevistas gravadas em áudio com a professora do curso e quatro professores-sujeitos, ou professores-alunos, que se dispuseram a concedê-la.

Para Van Lier (1998, p.53), um dos campos em que a Etnografia mais se desenvolveu nos últimos anos foi a Educação, parcialmente pela insatisfação com resultados positivistas que se apoiam em dados controlados. Para estudarmos o contexto da sala de aula e os pensamentos dos professores a respeito de sua prática, não podemos somente contar com aplicações estatísticas, mas combinar técnicas e utilizar uma variedade de métodos de coleta de dados, a fim de observar, identificar conceitos ou, mesmo, gerar hipóteses. Para o autor (Ibid., p.55), a Etnografia é guiada por dois princípios: êmico e holístico. O primeiro exige que o pesquisador despoje-se de medidas preestabelecidas, modelos, esquemas e tipologias, e considere o fenômeno da sala de aula sob um ponto de vista crítico, derivado do significado que os participantes desenvolvem e no qual investem, no contexto social da sala de aula, por meio da interação e de vários tipos de documentos (entrevistas, planos de aula, anotações, entre outros). O principio holístico, por sua vez, compara resultados em contextos culturais diferentes (VAN LIER, 1998, p.56).

Em nossa pesquisa, optamos por uma abordagem mais voltada ao primeiro princípio, êmico, em que observamos a orientação do curso e sua organização, para dar significado construído aos dados coletados ao longo do curso. O universo observado em sala de aula e nos diários foi, na sua totalidade, construído pelos professores, sem que orientássemos ou guiássemos seus registros escritos ou orais.

O objetivo da pesquisa foi, portanto, mapear as mudanças alcançadas pelo professor por meio de sua participação em curso de Formação, de modo que o papel do pesquisador fosse a de um observador dessa mudança, não participando ativamente desse processo, mas testemunhando-o.

Diz-nos Ferro (1998, p.4) que o estudo inicial da formação do professor de Inglês poderá revelar dados essenciais para a análise do contexto de ensino de Língua Inglesa, nos hoje denominados níveis Fundamental e Médio, especialmente em São Paulo. O mesmo parece valer para a Formação Continuada.

De acordo com Mc Donough (1997, p. 201), os métodos introspectivos são os mais viáveis na pesquisa escolar. Não há, para o autor, fórmula garantidora de uma boa pesquisa, bem como não há necessidade de um só método. De fato, o autor advoga pela conjunção de várias técnicas na coleta de dados, o que garantirá maior plausibilidade na 
interpretação. Segundo o autor (Ibid., p.203), um estudo de caso, dentro do paradigma qualitativo, não é um método de pesquisa, mas emprega combinações de vários métodos e diferentes técnicas, na investigação de um objeto de estudo. O Estudo de Caso tem um papel especial, em se tratando de pesquisa-ação, seja para o desenvolvimento do professor, seja para o da escola. É um caminho adequado para pesquisas sobre aquisição de LE. No entanto, o estudo de somente um caso pode impedir (ou falsear) a generalização de resultados.

O que é um Estudo de Caso, em nossa pesquisa? Seguiremos Mc Donough (1997) e diremos que estudamos um grupo de professores da rede pública, submetidos a um curso de Capacitação Metodológica. Nosso objeto de estudo está condicionado, portanto, a certos parâmetros, tais como:

1. trata-se de um contexto particular, em tempo delimitado (um ano de curso);

2. é um grupo com características próprias, cujo papel social é lecionar a LE a alunos do ensino público fundamental e médio da cidade de São Paulo;

3. os professores envolvidos participam de curso de Capacitação oferecido por instituição binacional localizada em São Paulo.

O objetivo de nosso estudo é detectar o processo de mudança em sua prática, enquanto frequentam o curso. À medida que a pesquisa desenvolveu-se, novas perguntas foram surgindo. O objeto de que tratamos é dinâmico, logo não sabíamos de antemão todos os focos que emergiriam; este Estudo de Caso focaliza, portanto, os efeitos do curso de Capacitação Pedagógica nesse grupo singular.

Atentamos, ainda, para as diferenças entre o professor aluno do curso e aquele que o ministra, aos quais denominaremos, respectivamente, professor-aluno e professor do curso.

Diz-nos Mc Donough (1997, p.214) que a escrita de diários é penetrante, ou seja, tem um sentido reflexivo, como observamos em exemplos da própria literatura, como Anne Frank, Malinowsky, Katherine Mansfield e outros. A análise dos diários presta-se, também, a ser uma técnica de pesquisa interpretativa microetnográfica (Ibid., p.121). Para Van Lier (1988, p.55), a escrita de diários claramente pertence à categoria daqueles procedimentos de coleta de dados em que coleta e seleção são minimamente controladas. 


\subsection{OS DIÁRIOS}

Goodson (1992, p.69) afirma que, particularmente na área de formação dos professores, há falta de um ingrediente principal: a voz desse professor. Tem-se dado ênfase à prática docente, com foco em seu aspecto técnico, mas é preciso, também e acima de tudo, escutar a pessoa a quem se destina o processo de formação, observa o autor. Ouvir, portanto, a voz do professor é de grande interesse, quando falam de seu trabalho. O autor continua:

Não considero este fato surpreendente. O que considero surpreendente, senão francamente injusto, é que durante tanto tempo os investigadores tenham considerado as narrativas dos professores como dados irrelevantes. As experiências de vida e o ambiente sociocultural são obviamente ingredientes-chave da pessoa que somos, do nosso sentido do eu (Ibid., p.69).

O que ressoa, ao falarmos em diários, é a mudança constante de tema e sua escrita processual. O diário é pessoal não somente no sentido de uma recriação da experiência imediata, mas também por ser documento escrito: o ato da escrita é uma maneira de estruturar, formular e reagir à experiência, que se torna disponível à nossa reflexão e análise (MC DONOUGH, 1997, p.122).

O formato de diário utilizado na presente pesquisa é o de "gênero aberto", ou seja, textos subjetivos em que informações factuais, reações, atitudes ou sentimentos estão presentes. Um problema a respeito da publicação dos diários é a questão ética e confidencial: nenhum texto pode ser publicado sem a autorização do escritor e, quando publicado, deve ser anônimo. Por essa razão, pedimos autorização (ver Anexo 4) por escrito aos professoresalunos, sujeitos desta pesquisa, para que pudéssemos inserir no trabalho excertos de seus diários, e alteramos seus nomes de modo a proteger sua identidade (ver Anexo 1).

\subsubsection{A natureza dos dados do diário}

De acordo com Mc Donough (1997, p.124), há quatro características identificadas nos diários. Primeiramente, o texto é muito rico, quantitativa e qualitativamente, com relatos sobre aspectos sociológicos, metodológicos e opiniões pessoais sobre alunos, aulas e a própria escola. Em segundo lugar, o uso da primeira pessoa do singular "EU" prevalece nos relatos, o 
que significa uma visão filtrada do que é observado, sentido e escrito. Uma terceira característica é a escrita retrospectiva dos acontecimentos, mesmo que seja sobre o dia anterior (ou logo após uma aula) - embora, como em autobiografias, haja certa margem de falta de precisão, ao passar do tempo, podemos concordar com Elliott (1991 apud MC DONOUGH, 1997, p.124), que afirma: "o diário designa sentimentos de como foi estar presente participando de uma dada experiência" ${ }^{1}$. Finalmente, a quarta característica dos diários são seus registros sobre o que aconteceu em sala de aula, o que o professor sentiu, o que deveria ter ocorrido, o que poderia ter mudado, reações imediatas e opiniões, além do tom reflexivo dos depoimentos. Os dados dos diários, portanto, orientam o pesquisador em seus procedimentos de análise. O foco de nossa pesquisa é o efeito do curso de Capacitação na prática do professor e, assim, lançaremos nosso olhar na densidade dos dados obtidos, a fim de analisar a mudança de comportamento do professor de LE, na interação com sua classe.

Uma função maior cumprida pelos diários é o que Holly (1994 apud MC DONOUGH, 1997, p.126) denomina de espaço particular, ou seja, um fórum para a reflexão. Mc Donough define o diário como um instrumento de trabalho, na medida em que é processado analiticamente. Bailey (1993 apud MC DONOUGH, 1997, p.126) argumenta que essa particularidade - de ser único e privado - torna-se pública, no momento em que ele é estudado para fins de pesquisa e torna-se, consequentemente, parte de um corpo de insights sobre os inobserváveis processos de ensino-aprendizagem de LE. Bailey (apud MC DONOUGH, 1997, p.126) sugere cinco olhares para observarmos os diários de professores:

1. como relato do cenário profissional;

2. como relatos confidenciais;

3. como possibilidade de publicação científica;

4. como fonte de análise de dados;

5. como estudo de interações e discussões.

Para o pesquisador, o procedimento de análise mais comum consiste em leitura e releitura dos textos, escritos a fim de que temas significantes surjam à sua frente. Observa-se, também, a recorrência de usos linguísticos, traços de estilo, grupos de palavras parecidas e outras peculiaridades. Um foco em especial pode se dar sobre os professores, sua metodologia ou, mesmo, sobre preocupações apontadas acerca de como ensinar certos aspectos da LE.

\footnotetext{
1 "it conveys the feeling of what it was like to be there participating in it" (em tradução livre: eles designam sentimentos de como foi estar presente, participando de uma dada experiência).
} 
Allwright e Bailey (1991 apud MC DONOUGH, 1997, p.125) mencionam três aspectoschave a serem considerados quanto à análise dos diários. São eles: (1) repetição ou refrão; (2) distribuição; (3) saliência, ou seja, a força da expressão a certos tópicos.

A repetição e a distribuição implicam uma possibilidade de conteúdo quantitativo, uma escala de força para a linguagem utilizada, por exemplo. Porém, no nosso caso em especial, a abordagem quantitativa não foi suficiente para analisar os dados; uma análise interpretativa foi necessária para dar conta de todo o contexto, abrangendo, assim, tentativas na recuperação, via leitura, das pressuposições, intenções e a cultura da sala de aula em questão.

Nunan (1992) lembra-nos que diários são ferramentas introspectivas e contribuem para registros documentais valiosos, a fim de estudarmos fatores afetivos que emergem no processo de ensino-aprendizagem de Línguas. Como um instrumento de coleta de dados, os diários podem trazer à luz um sistema de crenças subjetivas e a importância do contexto em que a aula acontece. Segundo o autor, esses aspectos da análise pertencem a uma tradição etnográfica de pesquisa.

Os dados registrados através de diários, bem como as observações das aulas e as entrevistas gravadas em áudio, foram transcritos neste estudo e estão apresentados nos anexos. Lier (1998, p.232) enumera diversos motivos que justificam a transcrição e a gravação de dados, dentre os quais citamos o uso como instrumento de análise da interação e das experimentações realizadas em sala de aula, o que, no nosso caso, propiciou a formação de corpus para um Estudo de Caso desse grupo particular de professores-sujeitos da pesquisa.

\subsection{A OBSERVAÇÃO COMO PROCEDIMENTO DE COLETA DE DADOS}

Ao nomearmos o procedimento de observação, referimo-nos a um "termo guardachuva", no dizer de Mc Donough (1997), ou seja, aquilo que pressupõe variadas finalidades e interpretações. A observação e as técnicas associadas à sua aplicação são frequentemente utilizadas na pesquisa etnográfica. Vários autores categorizam a observação como aberta, fechada, estruturada, semiestruturada, dependendo do grau de participação do pesquisador/observador. Mc Donough cita três parâmetros-chave na observação. São eles: (1)

o observador; (2) os objetivos; (3) os procedimentos. Em outras palavras: Quem? Por quê? Como? 
Quanto ao observador, o autor afirma que há um spectrum de maior ou menor participação. Mc Donough (1997, p.118) declara que é mais eficaz efetuar observações regulares por um período de tempo, pois elas permitem ao pesquisador a construção de um quadro do desenvolvimento cultural da sala de aula e ensejam a emergência de novas atitudes, novas descobertas. Foi o que procuramos fazer durante os dois semestres em que observamos o curso e tivemos contato com o grupo.

\subsection{A CLASSIFICAÇÃO DOS CASOS}

O Estudo de Caso pode ser classificado de várias formas, dependendo do objetivo proposto pela pesquisa. Aqui, partindo de Stake (1995 apud MC DONOUGH, 1997), nosso objetivo é a análise da instrumentalidade do curso de Capacitação Metodológica que observamos, ou seja, pretendemos observar de que maneira os professores-sujeitos da pesquisa apropriam-se dos conceitos teóricos e das técnicas pedagógicas a eles ensinadas. E, nesse processo, acreditamos, a mola mestra da ação encontra-se na reflexão que emerge da prática pedagógica (que aqui chamaremos "reflexividade"), bem como na reflexão sobre essa mesma prática.

\subsection{O CORPUS E SUA ANÁLISE}

O corpus da pesquisa é composto de vários tipos de registro:

1. transcrições dos relatos escritos pelos professores em seus diários reflexivos ${ }^{2}$;

2. transcrições do áudio das entrevistas gravadas;

3. transcrições do áudio da entrevista com a professora do curso de Capacitação Metodológica;

4. transcrições de anotações efetuadas durante a observação do curso de Capacitação Metodológica (anotações de aulas);

\footnotetext{
${ }^{2}$ Os problemas de norma padrão da língua portuguesa encontrados nas transcrições foram corrigidos, e as pausas não foram representadas.
} 
5. transcrições de observações da pesquisadora, durante aula de Inglês em escolas da rede estadual e municipal (anotações de aulas);

6. questionários com perguntas gerais, visando ao levantamento do perfil dos participantes (ver Anexo 3).

O programa do curso de Formação Continuada não consta desta lista, por não termos tido acesso ao material do convênio entre as duas instituições. No entanto, no decorrer da análise, serão apresentadas as linhas gerais delineadas no curso

A análise do corpus focalizou duas perspectivas metodológicas: a etnográfica contemplou o contexto da pesquisa (professores, alunos e desenvolvimento do curso) e foi realizada por meio de observações e anotações, levando-nos à descrição dos dados e À postulação de três momentos do curso. Além disso, a análise do contexto de pesquisa foi também complementada pelos dados obtidos nos diários escritos pelos professores-alunos em relação às mudanças percebidas.

O Estudo de Caso, por sua vez, também está aqui contemplado como perspectiva metodológica, já que os diários e entrevistas dos professores levaram-nos, por sua vez, a uma análise do grupo observado, cujo resultado vale para o grupo em questão, apenas apontando perspectivas de novas indagações em futuras pesquisas.

Os registros que obtivemos foram lidos e analisados. Utilizamos as seguintes categorias teórico-metodológicas, anteriormente mencionadas, para detectarmos o sentido que os sujeitos dão a suas aulas e a seus escritos registrados nos diários e entrevistas:

1. repetição ou refrão de expessões, palavras;

2. distribuição das mesmas;

3. saliência ou força com que os sujeitos se expressam.

A seguir, no capítulo III, focalizaremos o curso de Formação Continuada e passaremos a analisá-lo em seus momentos, à luz das teorias que foram descritas nos Capítulos I e II. 


\title{
CAPÍTULO 3 - A ANÁLISE DO CURSO E SEUS RESULTADOS
}

\author{
É importante que eles vejam a escola como um espaço \\ de que eles participem e do qual gostem, um espaço de \\ transformação da vida deles.
}

Professora Mariana

Neste capítulo, passaremos a analisar e interpretar o curso de Formação Continuada, tendo como referência sua observação ao longo de 2008. Três momentos serão aqui categorizados:

1. silêncio profundo: um olhar desviado ou uma forma de reflexão;

2. fala egocêntrica: um olhar sobre si mesmo;

3. em busca da autonomia: um olhar sobre a prática.

\subsection{O CURSO DE CAPACITAÇÃO METODOLÓGICA: UMA VISÃO PANORÂMICA DO CONTEXTO}

O contexto da pesquisa etnográfica sobre Formação Continuada teve como foco principal a observação do curso de Capacitação Metodológica oferecido por instituição binacional, conforme já apresentado no capítulo anterior. A turma era formada por professores da rede pública estadual e municipal, divididos em dois grupos. A pesquisadora observou um desses grupos, composto de 22 professores - dezoito mulheres e quatro homens, com idade entre 25 a 55 anos - e coletou diários dos participantes desses grupos. Boa parte deles (80\%) leciona Língua Estrangeira (Inglês) no ensino público, há mais de 5 (cinco) anos; 25\%, há mais de 10 (dez) anos; 5\%, há menos de 5 (cinco) anos. A grande maioria (99\% dos professores) formou-se há mais de 10 anos; $90 \%$ não têm formação específica para lecionar nas séries iniciais de ensino de LE, no Ensino Fundamental, e apenas $10 \%$ deles têm essa formação. A totalidade dos informantes (100\%) respondeu que veio fazer o curso de Formação para aperfeiçoamento; 25\% complementaram que vieram para aprimorar-se, aprender, partilhar estratégias, técnicas e métodos de ensino, além de atualização. 
Os professores acreditam que, no Ensino Fundamental, a Língua Inglesa seja importante para o desenvolvimento futuro dos alunos, já que esta é a base para o aprendizado; consideram a motivação como elemento essencial para o aprendizado; creem, também, que a ausência do material de apoio dificulta o envolvimento nas atividades de aprendizagem e que o ensino da Língua Inglesa pode ser feito através da música e de jogos. Também estão convencidos de que, quanto mais cedo for iniciado o ensino de Língua Estrangeira, melhor será o resultado, pois há maior interesse, os alunos são mais receptivos a atividades comunicativas e o lúdico torna-se estimulante. Os professores acreditam, também que o ensino da Língua Inglesa pode ajudar no desenvolvimento cognitivo e no aprendizado da língua materna. Mas, apesar de importante para a formação do aluno, seu ensino é avaliado como difícil, pela enorme diferença do idioma em relação ao português e pela quantidade de alunos em cada classe. Os professores acreditam que, nos primeiros anos do ensino de Inglês, os alunos têm grande interesse e estão prontos a aprender e, nas classes iniciais do ensino Fundamental II, os professores veem os alunos como muito receptivos ao Inglês, gostando de aprender a nova língua, embora sejam muito agitados. Os informantes entendem que a aprendizagem de uma língua estrangeira, desde cedo, proporciona ao aluno uma aprendizagem sólida nas séries seguintes, de forma mais fácil e mais agradável. Os professores também são unânimes na valorização do curso de Capacitação, que, segundo eles “abre espaço não só para sua capacitação metodológica, mas também para seu aperfeiçoamento linguístico".

A coleta de dados da presente pesquisa foi realizada a partir de março de 2008, quando se iniciou o curso, e finalizada em dezembro do mesmo ano, quando ele terminou. No primeiro dia de aula, informou-se aos sujeitos que a pesquisadora desenvolveria pesquisa relacionada à sua tese de doutoramento, sobre o tema "Ensino da Língua Inglesa na rede pública e o curso de Capacitação Metodológica” e que, para tanto, a pesquisadora acompanharia a turma, com a observação das aulas de Metodologia. Além disso, para saber a respeito do trabalho que desenvolviam nas respectivas escolas, ela pedia a colaboração de todos, na escrita de reflexões sobre as práticas de cada um dentro da sala de aula, focalizando o ensino da Língua Inglesa, suas dificuldades ou sucessos. Foi-lhes também solicitado que assinassem um termo de concordância (ver Anexo 4) para utilização dos dados, com garantia de preservação da identidade. 
Durante as aulas anotaram-se os registros principais das ocorrências observadas, incluindo-se as anotações sobre as informações e atividades propostas ao longo do curso. Neste capítulo, será feita a descrição dos aspectos que, durante a releitura dos registros e posterior análise dos dados, mostraram relevância quanto à frequência e intensidade no grupo.

\subsection{O CURSO DE CAPACITAÇÃO METODOLÓGICA E SEUS OBJETIVOS}

A seguir, observamos, no relato de Ariadne, a professora do curso, o objetivo de levar os professores-alunos a tornarem-se reflexivos e críticos acerca de sua própria prática. $\mathrm{O}$ curso inicia esse caminho por meio do aprendizado de métodos e abordagens teóricas de ensino-aprendizagem da Língua Inglesa, fazendo uso de uma mescla de modelos Craft e das Ciências Aplicadas, na categorização de Wallace. Ariadne nos disse, desde o primeiro contato, que os professores-alunos precisam conceber, primeiramente, o ensino de LE de outra forma que não simplesmente o aprendizado de regras gramaticais. Em entrevista oral, a professora frisou que comunicação é o alvo, ao se falar uma outra língua e, portanto, o curso é desenvolvido a partir de uma abordagem comunicativa:

\section{Professora Ariadne}

Vou começar falando um pouquinho sobre os objetivos do curso.

$\mathrm{O}$ nosso maior objetivo é que os professores tornem-se reflexivos e críticos da sua prática. Esse eu acredito que seja o nosso maior objetivo; é claro que para chegar a esse maior objetivo [...] a gente tem que passar por outros caminhos primeiro. No início do curso, no primeiro semestre, a gente tem um objetivo menor, que será familiarizar os professores com diferentes métodos e abordagens, teorias de aprendizagem de Língua Inglesa e também tentar fazer com que eles saiam um pouco dessa metodologia, eu diria, tradicional, que é o que a gente percebe que eles mais usam.

Pelo perfil dos professores, no início, com relação à metodologia e abordagem de como ensinam a língua para os alunos, a gente percebe que é através do método tradicional, usando a tradução, certo? Tendo essa visão da linguagem como um sistema de palavras de signos ou de regras gramaticais, eles acabam ensinando assim e tentando passar isso pros alunos. Num primeiro momento, a gente tenta fazer com que eles enxerguem a língua ou o ensino da linguagem de uma outra forma e isso quer dizer que ensinar a língua não é só ensinar regras 
gramaticais. Então setenta mudar um pouquinho essa visão e a gente tenta mostrar as possibilidades de outros métodos.

Acaba sendo uma coisa muito rápida, porque o curso tem duração de um ano, mas assim a gente mostra para os alunos-professores as possibilidades de método que a gente tem, e tenta-se fazer a transição de uma abordagem mais tradicional para uma abordagem menos tradicional, para uma abordagem comunicativa, pensando que esse seria o grande objetivo hoje, das teorias atuais, inclusive dos Parâmetros - os PCNs estão fundamentados nesse princípio da linguagem como comunicação, tendo como meta a comunicação então a gente tenta, mais pro final do curso, passar isso pra eles: como transformar uma aula em que você ensina a língua de uma maneira tradicional - regras, palavras, fazendo a tradução - para uma aula mais comunicativa. E eles vão sempre refletir sobre esses conceitos, fazendo atividades práticas.

Confirma-se, portanto, por meio do relato de Ariadne, a idéia mestra que sustenta a trajetória do curso de Capacitação Metodológica: provocar a reflexão. Seu maior objetivo é mapear a mudança de comportamento do professor-aluno, buscar o desenvolvimento de competências fundamentais que lhe permitam pensar e repensar a prática. Como referência para as discussões sobre a prática docente, muito presentes no segundo semestre, era sempre incentivado o questionamento "Estão meus alunos realmente aprendendo?" E sempre que isso ocorria, eram discutidos no grupo possíveis caminhos para a obtenção de melhores resultados.

Brown (2001) é um dos autores trabalhados ali e sustenta a proposta orientadora do curso de Capacitação, servindo de referência para a entrada no campo da reflexão. Para o autor, os professores têm a seu dispor vasta literatura sobre ensinoaprendizagem de LE, fruto de trabalhos da última década do século XX. Nesse sentido, a prática deve aliar-se à pesquisa, a fim de que os aprendizes - crianças, adolescentes e adultos - alcancem seus objetivos. Ele propõe, ainda, princípios pedagógicos para o ensino de LE que reflitam um ensino-aprendizagem significativo, e não apenas uma tradução mecânica ou memorização de regras. Saber uma LE, para o autor, exige investimento, esforço, atenção e tempo, recursos que tornam o aprendiz autônomo cada vez mais.

Brown (Ibid., p.61) dá atenção aos princípios afetivos fundamentais para que se faça o elo cultural entre língua materna e língua estrangeira. Ele afirma que, nos sentimos fragilizados frente à aprendizagem de uma LE; o professor, desse modo, deve dar atenção a esse aspecto do processo, a fim de aliviar sentimentos de humilhação, ou a famosa queixa dos alunos: "Travei!" 
$\mathrm{O}$ autor elege o princípio da autoconfiança como aquele que auxilia o aluno a alcançar sucesso em sua tarefa de aprendizagem de uma LE: o professor que reconhece a capacidade do aluno consegue derrubar o muro de defesa que impede este de aprender melhor e permite que se arrisque, sem medo de errar. Arriscar-se é fundamental para o aprendizado de uma LE, pois a competência comunicativa pressupõe diversos níveis de aprendizagem: há níveis de fluência que devem ser levados em conta, em especial quando se leciona em escolas da rede pública de ensino, nas quais muitos alunos são iniciantes (BROWN, 2001, p.68-69).

A defesa dos princípios afetivo, da autonomia e da autoconfiança acaba, sem dúvida, atingindo os professores de forma espelhar, como alunos e como profissionais de ensino. Nesse sentido, incitam a reflexão de suas práticas e das práticas do outro. O outro, no caso, diz respeito à professora do curso de Metodologia - que ora atua como "modelo ideal de ensino", ora como "questionadora" de práticas, incentivando a pesquisa e a reflexão sobre elas - e aos professores de Língua - que atuam como eventuais "modelos para reflexão", uma vez que oferecem uma nova "vivência de aprendizagem". Sem falar nos demais professores-alunos, especialmente

quando das apresentações em aula. Apesar de não termos observado as aulas de Línguas, algumas considerações sobre elas, feitas pelos próprios professores-alunos, tanto no curso de Metodologia quanto em conversas informais, deixaram transparecer que, além da motivação por estarem "melhorando o seu inglês", utilizavam "muitas atividades do curso para serem adaptadas para seus próprios alunos". Nos comentários, foi muito comum dizerem: "Está sendo bom porque também mostra como é uma excelente aula de Inglês". E acrescentavam: "Claro que é preciso adaptar à nossa realidade de escola pública, pois aqui é diferente".

\subsection{A TRAJETÓRIA DO CURSO E SEUS PRINCIPAIS MOMENTOS}

As observações feitas no curso de Metodologia permitiram que fossem percebidos três momentos distintos, com características bastante particulares. Ao nomearmos cada uma delas, buscamos deixar transparecer ao leitor um movimento de 
mudança, com as principais marcas do processo ocorridas ao longo do curso. A seguir, a descrição e análise de cada uma delas.

\subsection{1 "Silêncio profundo"}

Este primeiro momento em que os professores-alunos reagiam passivamente à fala da professora do curso resgatou a imagem da sala de aula como um "universo estático", em que o aluno se posiciona como "tabula rasa", sem nenhuma participação, numa relação totalmente assimétrica. Observamos uma situação de ensino em que o professor fala enquanto os participantes do curso escutam-no em silêncio.

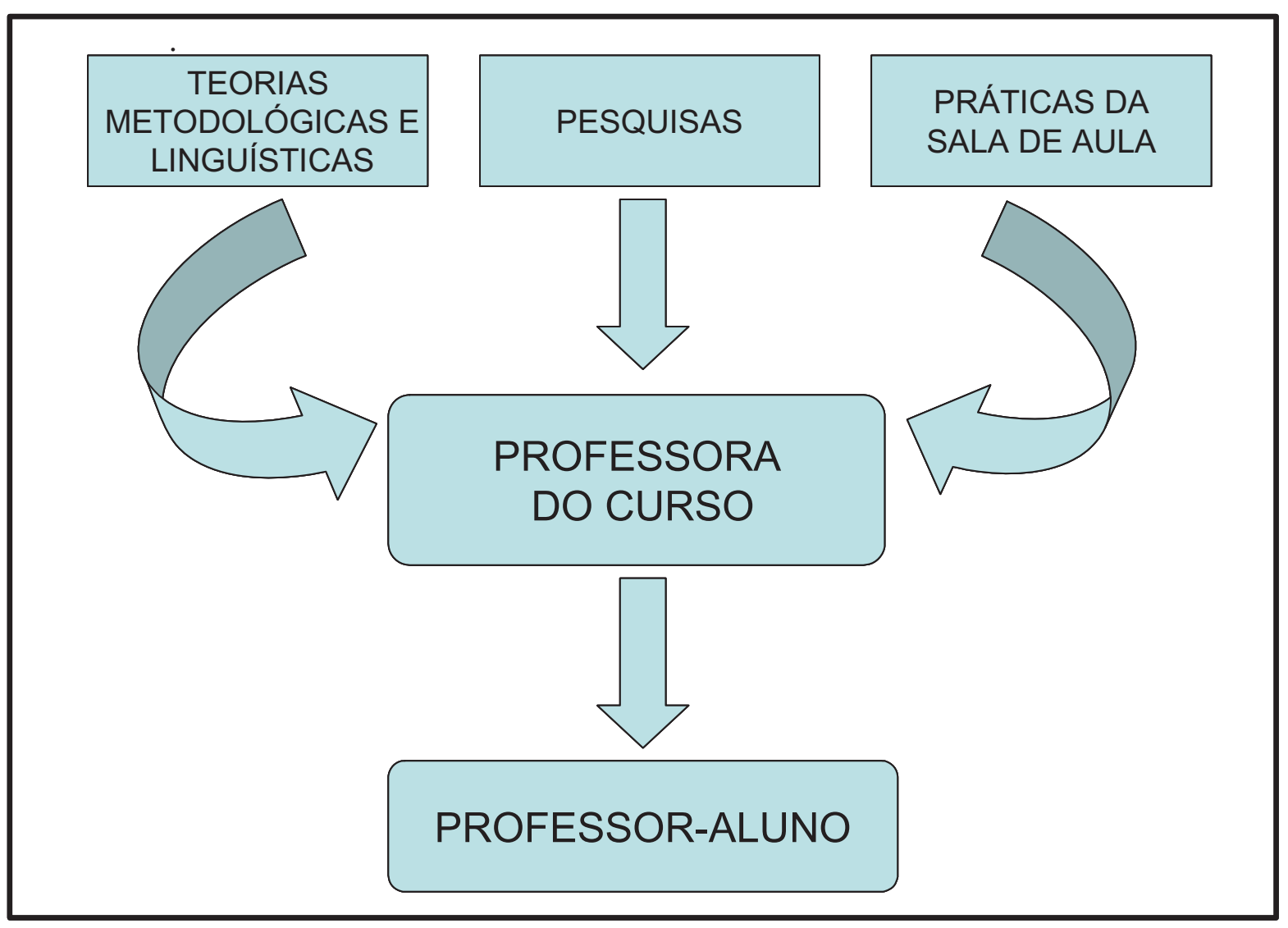

Figura 1: Modelo - aluno receptáculo de informações /modelos.

Vemos, portanto, na figura, a ilustração de ocorrências em que os professores-alunos do curso de Capacitação encontram-se na base, como receptáculo do conhecimento. No centro está o professor do curso, caracterizando, assim, aquilo que já 
foi citado a respeito do que ocorre no início do curso: o uso de conhecimentos teóricopráticos provenientes das ciências aplicadas e da utilização do modelo Craft de Wallace.

A passividade e o silêncio manifestaram-se, tanto durante as aulas como na escrita dos diários. Talvez possamos explicar esse silêncio com Monteiro e Giovani (2004, p.130), que atribuem uma atitude desse tipo como possível frente ao novo: um bloqueio e uma resistência naturais. Ou mesmo como um desconforto em aprender, uma ameaça à sua identidade (HERNANDEZ, 1998 apud MONTEIRO; GIOVANI, 2004, p.133), contrariando toda a bagagem já sedimentada ao longo de anos, com estilo próprio e maneiras de ensinar já arraigadas em sua história de vida profissional.

A interpretação desse primeiro momento permite-nos levantar um leque de suposições a respeito da reação desses informantes. Uma delas advém do próprio curso e sua organização. Como já observamos anteriormente, a utilização do modelo Craft, somado ao das Ciências Aplicadas, condiciona o professor-aluno a assumir o papel de ouvinte e observador, portanto, calado. Além disso, como durante as aulas é utilizada a língua inglesa em boa parte do tempo (apenas em alguns momentos a professora traduz o que foi dito), o bloqueio natural de não querer se expor seria previsível, ora pela natural condição de intimidação, ora pela insegurança, fragilidade e dificuldades no uso confortável da língua. Esse silêncio não está, portanto, desprovido de sentido, no que diz respeito ao curso e sua organização.

Talvez possamos ver nesse silêncio um aspecto positivo no desenrolar do curso: resultado ou até uma garantia para a introspecção e análise crítica, sintomas da reflexão em processo. Ele pode ser, portanto, também lido como marca de questionamento interior, resultante do conflito entre o que é já conhecido e o que se projeta como novo e como proposta de mudança. Como diz Demo (1997, p.17) “o que pode ser visualizado como novo é a perspectiva de que o conhecimento, em vez de produzir certezas, é marcantemente uma estratégia de desmontá-las. Porém, parece ser mais uma habilidade de lidar criativamente com a incerteza". Podemos ilustrar essa condição de introspecção e análise crítica com a descrição de uma passagem do curso em que eram apontadas as diferenças entre o ensino tradicional e o ensino comunicativo. Os alunos ouviam calados as explicações que eram dadas em inglês.

Pela observação do grupo foi também possível constatar a atenção bastante focada naquilo que era apresentado. Além disso, a movimentação do corpo, expressões faciais e gestos não controlados como segurar a cabeça com as mãos, ajeitar-se nas 
carteiras, lançar o corpo para frente (certamente para ouvir melhor e garantir a continuidade de atenção ao que era falado na LE), entre outros, denotavam que os participantes estavam absortos no que estava sendo feito e, ao mesmo tempo, provavelmente pensando nas relações entre o que era dito e a realidade, num esforço incomum para compreender e assimilar a indagação feita pela professora.

O silêncio, nesses momentos de apresentação de teorias de ensino e de possibilidades de contraste com a realidade profissional, poderia ser necessário como tempo para "digerir" toda a teoria recebida, até se conseguir estabelecer relações com o cotidiano escolar, para depois falar sobre um assunto recém-aprendido. Ou poderia também constituir-se em um desafio de grandes proporções aos professores-alunos que, iniciantes no curso, sentiam-se curiosos e receosos sobre o futuro desse curso, o que seria cobrado deles e a aplicabilidade daquelas informações à sua prática. Decorridos três meses, sua trajetória começou a mudar, com a proposta de situações-problema levadas a eles, que, embora ainda ficassem a maior parte do tempo silenciosos, passariam então a ser chamados a participar. $\mathrm{O}$ exemplo a seguir ilustra uma ocorrência desse tipo, em que a professora do curso iniciou a aula sobre escrita em inglês com a seguinte afirmação:

Showing the students only the finished works and not the process is the same as taking them to a Magic show, and upon returning to the classroom asking them to pull a rabbit out of their hats.

Mostrar aos alunos somente o trabalho acabado e não o processo é como se, após assistirem a um show de magia, ao retornar à sala de aula aos alunos fosse solicitado que tirassem um coelho da cartola.

\subsubsection{Fala egocêntrica: um olhar sobre si mesmo}

Após seis meses, paulatinamente, os professores-alunos foram começando a se expor e falar sobre suas aulas na rede, seus alunos, problemas e dificuldades de aplicação do que estavam aprendendo. Essa mudança passava a acontecer principalmente pelo próprio andamento do curso de Capacitação Metodológica que, agora, passava a exigir dos professores-alunos um questionamento sobre seu ensino de Inglês, levando em conta os referenciais teóricos trabalhados no 
curso durante o primeiro semestre. A professora-aluna Ceci observou que seus alunos, acostumados com o ritmo de ensino de outra professora, resistiam à mudança a favor da qual Ariadne argumentava, com ênfase na importância da transição para uma nova abordagem, uma nova postura: o ensino da LE na rede pública, enfatizava Ariadne, deveria pressupor o desenvolvimento de aulas fundamentadas em um trabalho contextualizado e de currículo planejado em espiral.

Nesse trabalho contextualizado, explicava a professora do curso, mais do que simplesmente recriar situações variadas em sala de aula, tais como "na lanchonete", "na escola", "na loja de roupas", o contexto deveria propiciar a reflexão sobre as intenções e escolhas dos interlocutores envolvidos em atos de comunicação. Por vezes, a ideia de que a competência comunicativa não se restringe à oralidade, pois permeia toda atividade da linguagem era trazida à discussão do grupo.

A visão de que competência comunicativa é "saber a língua em contextos específicos" era retomada no curso de Metodologia para que os professores-alunos pudessem estabelecer relações entre o que estavam aprendendo nas aulas de Língua Inglesa (no curso de Capacitação Linguística) e o que era tratado no curso de Capacitação Metodológica

Ariadne demonstrou, em classe, aulas possíveis de desenvolvimento das quatro habilidades, isoladas ou integradas, seguindo os passos pre, while, e post ou prétarefa, tarefa e pós-tarefa. Os professores, por sua vez, traziam à aula suas angústias, tais como a preocupação em falar a língua inglesa, preocupação maior do que a de seguir a nova abordagem.

Após demonstração de uma aula de escrita, Ariadne lançou uma pergunta aos professores: "É possível dar uma aula como esta a seus alunos?" A resposta de um professor veio com um senão: "Depende. Classes barulhentas não colaboram, os alunos são desmotivados." E Iara, outra professora, trouxe as restrições do livro que se adota na sua escola. Ariadne, então, continuou com a pergunta: "É possível adaptar essa atividade?". Nesses momentos, era comum um professor relatar algum tipo de reprodução com algumas de suas classes do que havia aprendido no curso de Metodologia ou de Língua.

A partir de junho, portanto, é que pudemos verificar mudanças no comportamento dos professores, que começaram a tomar a palavra, a falar, a verbalizar o que ocorria dentro de suas salas de aula. Aparentemente, quase seis meses foram 
necessários para a pesquisadora detectar mudanças e a tomada da palavra pelos professores da rede, e ouvir essas vozes foi um marco relevante e ainda mais relevante foi o fato de que eles tinham o que dizer. Falavam de si mesmos e da busca de um modelo que, imaginavam eles, o curso de Capacitação pudesse oferecer e que percebiam não existir. A partir desse momento "mágico", o foco da aula, que fora na professora, dividiu-se, e passou a incidir sobre ambas as partes, o que tornou a relação mais simétrica.

Outras mudanças no que diz respeito aos conhecimentos teóricos trabalhados no curso foram também notadas pela pesquisadora.

Uma das primeiras mudanças ocorreu no início da aula do dia 27 de junho, quando Ariadne solicitou aos professores da rede que desenhassem uma representação de aprendizagem de leitura, fazendo uso dos modelos teóricos apresentados sobre o tema. Ariadne escreveu na lousa:

\section{What have you learned about reading? \\ O que vocês aprenderam sobre a leitura?}

Os professores-alunos foram divididos em três grupos. A tarefa era representar, com toda liberdade, a leitura e as estratégias de leitura que já haviam sido discutidas no curso. Os trabalhos representando leitura foram fotografados pela pesquisadora e apresentam-se a seguir: 


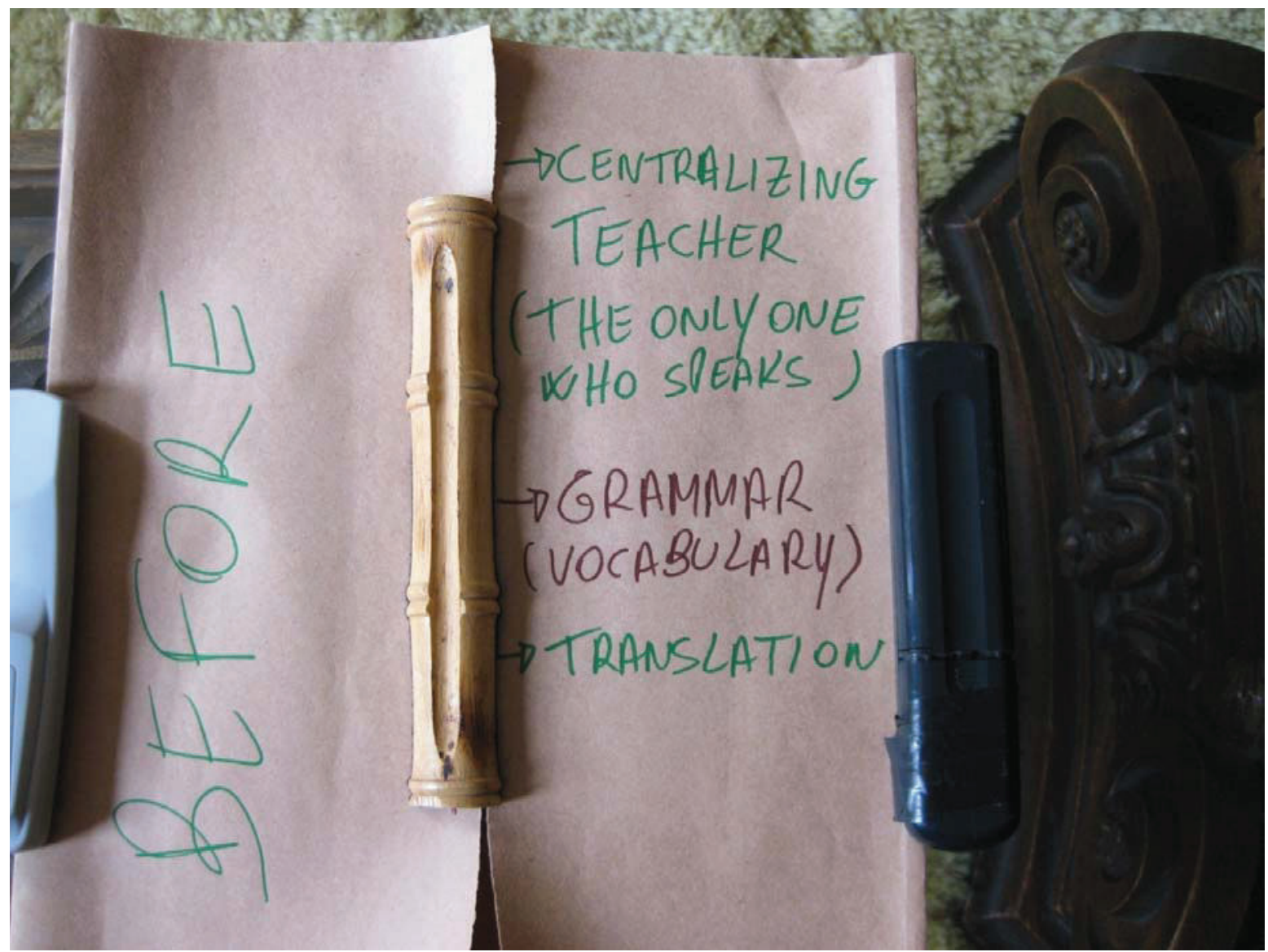

Foto 1 A: "Antes" - A abordagem tradicional (grupo 1).

O antes, nomeado pelo grupo 1 de "A abordagem tradicional", mostra uma janela fechada (tem também a aparência de um livro) com 2 lados. Em um deles está escrita a palavra "before", na vertical; do outro, três características bastante marcadas ao longo do curso, em relação à abordagem tradicional, referindo-se ao professor como figura central e única da aula, e à tradução (ambas escritas com a mesma cor da palavra "before"). Uma terceira palavra, escrita em outra cor, refere-se a "grammar" (gramática), explicitada como "vocabulary" (vocabulário). Enquanto no primeiro item apontado, "centralizing teacher", há entre parênteses uma explicação do significado, trabalhada e vivenciada com insistência no curso, o item "gramática" vem explicitado apenas como "vocabulário". Possivelmente essa "redação" na definição de gramática represente o conhecimento limitado desses professores sobre o assunto e também o que 
eles fazem em suas aulas, restringindo o ensino da gramática (por muitos visto como ensino da língua) a listas de palavras soltas.

De qualquer modo, as duas fotos (o antes e o depois) são representativas do curso e de sua organização, do que foi apresentado sobre teorias (do que puderam reconstruir sobre o processo vivido até então) e, simbolicamente, representam uma mudança (note-se a diferença de utilização das dimensões dos planos das fotos 1A e 1B (abaixo): de "primeiro plano" a uma dimensão espacial.

As janelas abertas, o sol (cortado ao meio) e a palavra "after" (em cor diferente das demais, mas igual à do céu) podem, simbolicamente representar o novo, a descoberta, a luz do conhecimento. O "after" (depois), denominado "novidades da abordagem comunicativa", ao ser colocado para fora da janela, ao mesmo tempo que pode representar algo que é almejado (no alto), pode também simbolizar algo que ainda não faz parte do contexto (que ainda estaria em processo de organização). O sol pela metade pode bem refletir essa etapa provisória. Um dado interessante que pode até ser representativo desse processamento ainda provisório (e limitado) do conhecimento é a escrita do $1^{\circ}$ item: "structure more read" (na verdade, structure plus reading), referindose ao "processamento da leitura" e às relações entre a estrutura textual e o ato de leitura. 


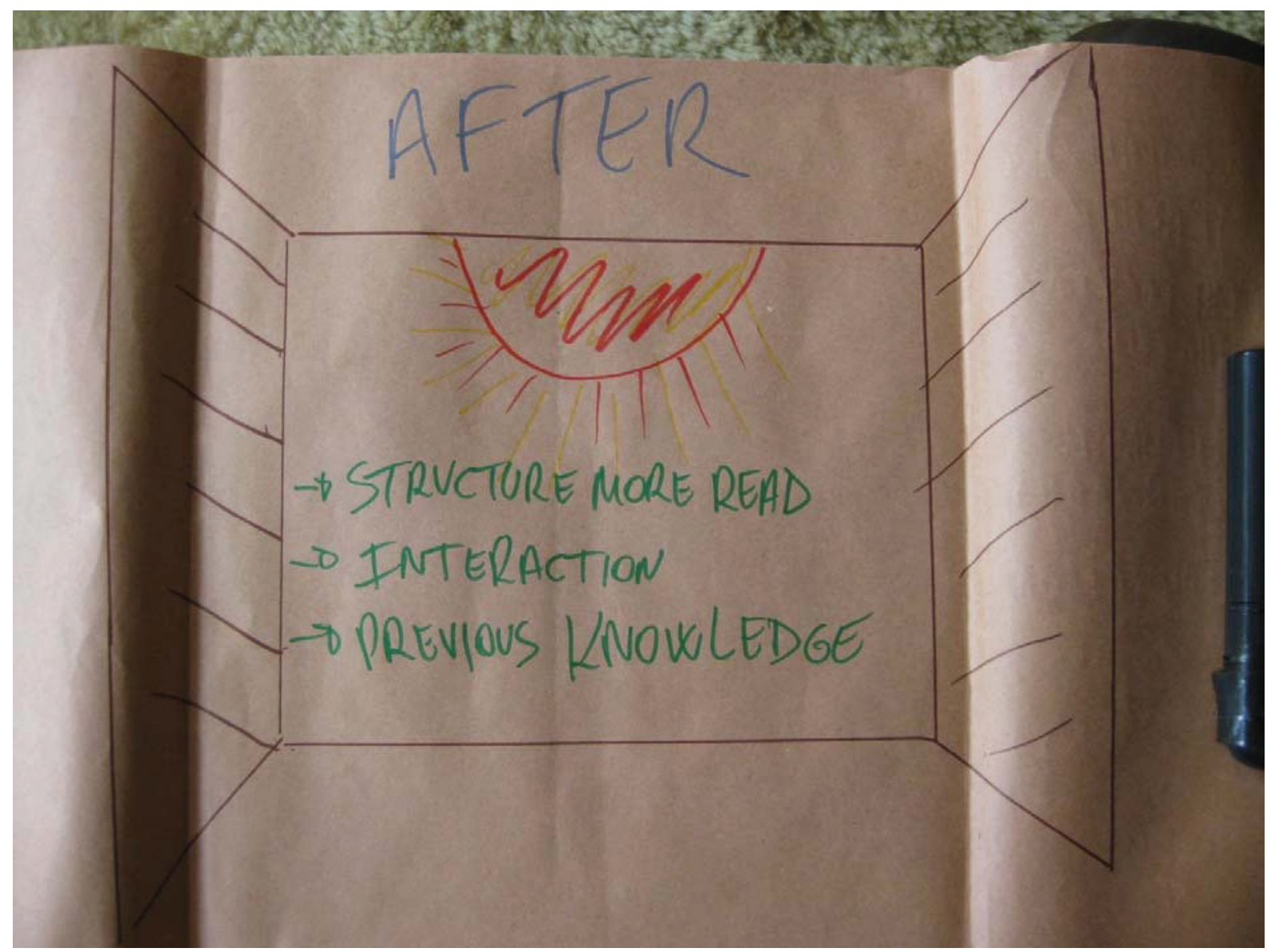

Foto 1 B: "Depois" - novidades da abordagem comunicativa. 
75 
grupo até então e qual a visão do seu conhecimento sobre leitura, restrita às informações dadas em aula pelo professor. Trata-se, portanto, de uma mera recuperação ou reprodução do que foi informado.

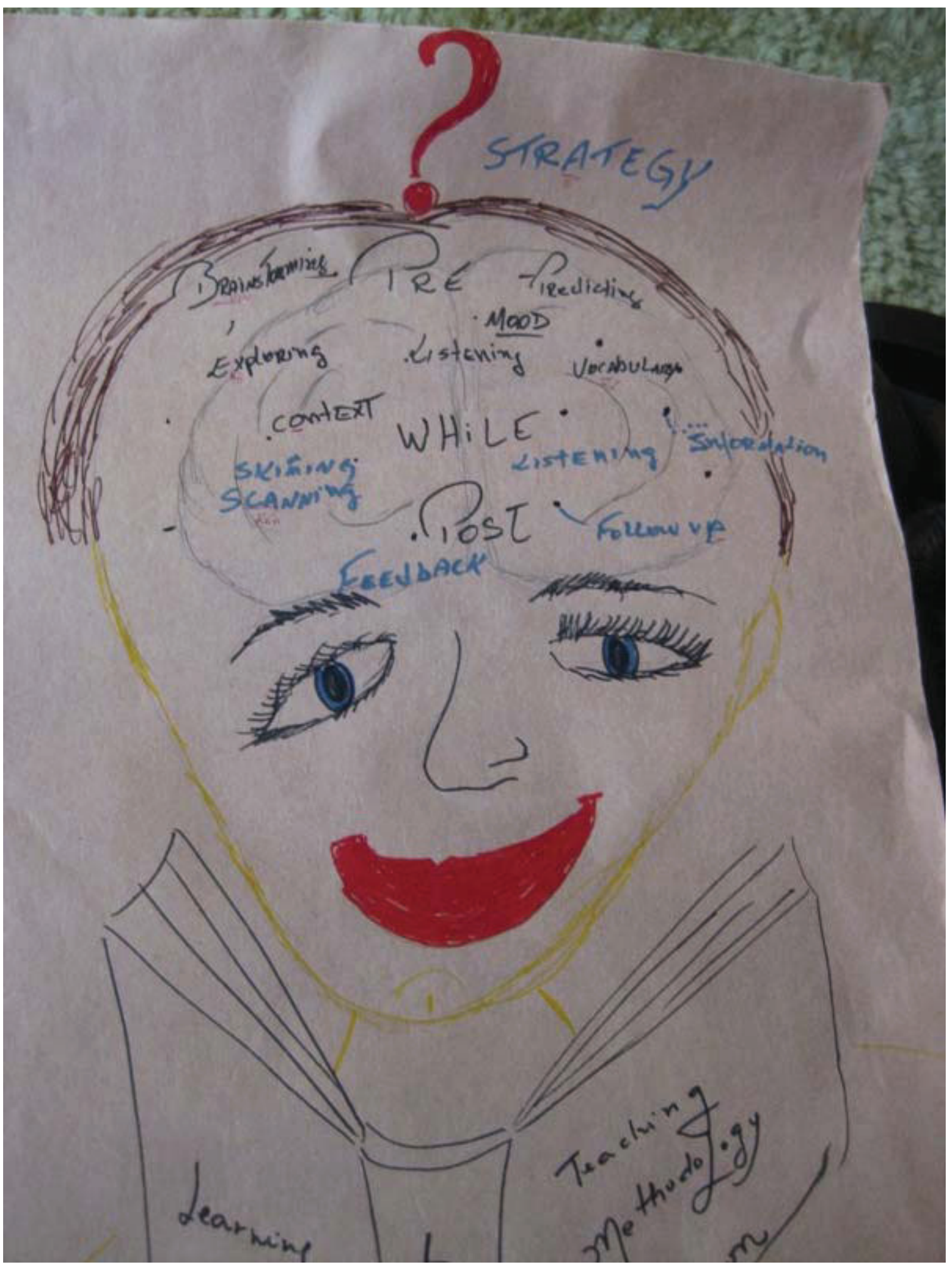

Foto 3: Novos conhecimentos adquiridos pelo professor-aluno sobre como dar uma aula de leitura. 
Vemos, no trabalho do grupo 3, uma representação mais abrangente do curso: no cérebro, muitas informações que aparentemente "pesam" sobre o rosto "sorridente" e "feliz" da figura que "lê" um livro escrito em inglês. Em que pese a possibilidade de múltiplas interpretações sobre as três representações dos grupos, procuraremos relacionar essas representações com o andamento do curso, desde o seu início até o momento em que se deu essa atividade. Obviamente nossa interpretação é apenas uma possibilidade de "leitura" e compreensão desse material, circunscrita à nossa visão como observadora do curso.

Podemos, portanto, observar os registros visuais que reproduzem graficamente o conhecimento adquirido no curso, graças ao estabelecimento de um processo que envolveu repensar os princípios que norteiam a leitura e o seu ensino, entre outras coisas.

Durante a elaboração das diversas atividades em grupo e em sala de aula sempre ocorriam discussões que provocaram efetiva troca de experiências e saberes, 0 que na visão de Nóvoa (1995, p.26) consolida espaços de formação mútua. Em grupos, o diálogo é fundamental para a consolidação dos saberes emergentes e, aos poucos, o exercício da profissão docente "ganha corpo". Essa troca foi também possível graças à possibilidade que se deu aos participantes, individualmente ou em grupos, de apresentarem aos demais as suas considerações, ora reafirmadas ora contestadas por outros, o que gerou clima de debate constante, porém de muito respeito. Essa abordagem participativa também auxiliou seus participantes a assumirem uma linha de trabalho mais centrado na colaboração.

\subsubsection{Em busca da autonomia}

Em uma das aulas do segundo semestre, Ariadne enfatizou os mesmos passos, as mesmas tarefas, trabalhadas anteriormente, relacionados, agora, à escrita em LE e iniciou a aula com as seguintes citações:

Students need to be personally involved in the writing activities to make it the learning experience of last value. 
Alunos precisam estar pessoalmente envolvidos na escrita, para que ela seja uma experiência de valor duradouro.

When students communicate experience, they resort to their intellect, emotions, and imagination, releasing their creativity, memory, and emotions. They will then, have authority over their own writing.

Quando os alunos comunicam suas experiências, põem em ação intelecto, emoções e imaginação, liberando criatividade, memória e emoções. Eles terão, então, autoridade sobre sua própria escrita.

Os professores liam essas citações e reagiam com relatos sobre suas experiências em sala de aula. Ricardo, um dos mais quietos do grupo, comentou a respeito de uma redação sobre corrupção, proposta aos alunos. Observou que o tema já havia sido trabalhado nas aulas de Língua Portuguesa, através da leitura de manchete de jornais e, com esse primeiro contato com o tema, foi mais fácil para os alunos transferirem o conhecimento que tinham do assunto para seus escritos em inglês. Ficou, portanto, clara, naquele momento, a importância do conhecimento prévio do assunto para o processo de escrita. Felícia, por outro lado, iniciou uma fala sobre produção de texto e disse que havia lido um determinado tópico em sala de aula, o qual foi compartilhado com os alunos e, posteriormente, explorado em leitura, porém alguns de seus alunos da rede não conseguiram acompanhar essa leitura. Ela desabafou que não é alfabetizadora e não consegue lidar com esses alunos que não são totalmente alfabetizados. O que fazer?

Naquele momento alguns participantes salientaram a necessidade de conhecerem técnicas que possam "minimizar" esse problema e admitiram que muitas vezes não atuam no sentido de ajudar os alunos, quando estes apresentam dificuldades. Discutiram-se, inclusive, vários casos que deveriam ser trabalhados pela escola, envolvendo todos os professores, sendo um deles a dificuldade da leitura e escrita advinda do processo de alfabetização.

A professora Ariadne, à medida que o curso transcorria, abria espaço para questionamento sobre a prática docente, mas de forma bastante organizada e coordenada. E, como já mencionamos, sempre pedia aos professores que pensassem em adaptações para sua realidade. Em uma dessas aulas, utilizou uma canção, para iniciar a habilidade de compreensão oral em língua estrangeira: a letra da canção continha palavras erradas e a tarefa era corrigi-las na lousa. Ao final da tarefa, Ariadne perguntou se seria possível trabalhar com música com os alunos da rede e os professores 
responderam que sim. Iara comentou que "passou música" para seus alunos de Diadema; Jaci fez comentários sobre exercícios diversos, como colocar duas palavras diferentes para seus alunos escolherem a correta; Ricardo mencionou um exercício com sons semelhantes; Gary lembrou como a música poderia ser usada para ensinar falsos cognatos, e Roxane comentou que se utiliza de música para praticar verbos irregulares. Iara sugeriu uma lista de músicas e apontou a música apresentada por Ariadne (California Dreaming) como interessante para o estudo de palavras sobre tempo e cores. Todos, enfim, enfatizaram o fato de os alunos gostarem dessa atividade e do prazer que sentem quando os alunos participam das aulas.

As vozes do professores, nesse momento, fizeram-se ouvidas e formas diversas de exploração de música em inglês para o aprendizado foram lembradas: a professora Ceci relatou o uso de exercícios com músicas, em turmas de EJA (Educação de Jovens e Adultos) e mencionou ter feito atividades, baixando-as da internet; o professor Gary sugeriu tentar o uso da música Logical Song, dizendo ser muito boa para aulas de Inglês, por ter uma profusão de adjetivos. Em suma, sentiu-se um dinamismo maior na sala de Capacitação; os professores pareciam dominar técnicas para explorar músicas em inglês e, pela primeira vez, "socializaram" suas experiências, com efetiva troca de ideias e sugestões.

Essa tomada da palavra pelos professores, no tratamento de tema como "ensino de Inglês através da utilização de música" foi um marco nas mudanças de trajetória do curso. O porquê dessa nova orientação no curso de Capacitação deixou espaço para algumas indagações. Talvez o tema tenha auxiliado na participação dos professores-alunos por fazer parte do seu cotidiano de ensino, talvez esse assunto tenha acontecido em momento de perfeita interação e integração do grupo ou talvez a mudança tenha ocorrido nesse momento por mera casualidade.

Ainda, em razão da variedade de aplicações de aulas para o contexto da rede pública e as perspectivas de adaptações à realidade de cada um dos participantes do curso, os modelos apresentados teriam sido mais motivadores que os anteriores, o que teria gerado mais envolvimento por parte deles? Afinal, dado um modelo eram sempre sugeridas adaptações ou aplicações, levando-se em conta a realidade profissional de cada um dos participantes. Esperava-se que, em algum momento, essas aplicações gerassem reflexões a respeito do como ensinar. Teria sido esse o momento? A verdade é que essa orientação do curso e a aula sobre o ensino através da música trouxeram 
resultados positivos para o grupo, com a participação cada vez mais ativa dos professores-alunos.

Do mesmo modo, observamos situações em que surtiram efeito as demonstrações de Ariadne e suas indagações para o grupo sobre como elas poderiam ser adaptadas a outros contextos. Um exemplo desse tipo de ocorrência foi verificado em uma atividade do tipo "jogo com bola", na qual os professores-sujeitos postaram-se em círculo para a prática de inglês oral, com perguntas e respostas. A professora do curso lembrou-lhes que a mesma atividade poderia ser feita em sala da rede, passando-se a bola aos alunos sentados nas fileiras, sem necessidade de muita agitação. Os professores deram exemplos variados de aplicações para o jogo com a bola e mostraram-se motivados para usá-lo com seus alunos.

A partir do final dos meses de setembro e outubro e, até o final do semestre, sentiu-se que os professores-sujeitos identificavam-se cada vez mais com a profissão de professores de Inglês e pareciam ter "descoberto" como descrever ou relatar uma aula. Passaram, também, a usar mais a língua estrangeira, demonstração de maior confiança quanto ao seu uso. Mostravam-se bastante pró-ativos, principalmente no momento da elaboração do projeto final e avaliaram o que foi aprendido no curso como importante para as mudanças que estavam propondo nas suas escolas: "pequenas ainda, mas com resultados muito positivos para toda a comunidade escolar", como declarou Roxane, em sua apresentação sobre o trabalho final. Alguns comentaram como os alunos adoravam falar em inglês e como se divertiram com a apresentação da festa de Halloween nas respectivas escolas. A iniciativa de propor essa festa de Halloween em suas escolas foi desses professores, em sua maioria; alguns pela primeira vez, incentivados pelos demais. Chegaram, inclusive, a apresentar projetos de ensino interdisciplinar, indicando a pertinência de trabalho integrado como elemento motivador para o aprendizado dos alunos e também dos professores das áreas envolvidas.

Projetos de tal natureza, para Perrenoud (2000), exigem capacidade de organização e de solução de problemas, tanto para os professores como para os alunos. O autor chama a atenção para o fato de que as "questões-problema" surgidas nas elaborações de projetos mobilizam novos saberes, novas regras e modos de cooperação.

Uma das últimas aulas do curso de Capacitação foi dada em uma única classe aos dois grupos de professores de rede. O clima foi muito bom. Todos falavam e contavam experiências, avaliavam suas próprias aulas e davam exemplos de atividades 
realizadas em sala. Fizeram um balanço retrospectivo de tudo o que haviam aprendido naquele ano, o que Nóvoa (1995) considera o momento em que cada professor produz "sua vida" e, neste caso, também produz "sua profissão". O grupo assumiu que continuaria o contato com a instituição e também entre os participantes, via e-mail, criando um grupo de discussão.

\subsection{UM POUCO MAIS SOBRE OS DADOS}

Os dados analisados realmente confirmam que houve mudanças visíveis nos participantes do curso, ao longo de seu desenvolvimento. A mudança primeira foi centrada na voz do professor da rede que, inicialmente, perdia-se ao tentar discorrer sobre a aula de Inglês, mas, após seis meses, iniciou o relato de casos e experiências de ensino, com a utilização de diversas técnicas trabalhadas no curso. Essa mudança refletiu um passo importante no processo de identificação do professor de Inglês da rede: seu ofício salientou-se nos relatos e nas discussões no curso de Capacitação metodológica. Como nos diz Nóvoa, é necessário que o professor reflita sobre sua profissão; essa reflexão é um caminho para o desenvolvimento pessoal e profissional. No dizer do referido autor (1995, p.25) um curso de formação deve estimular uma perspectiva crítico-reflexiva que forneça aos professores os meios para o pensamento autônomo. Certamente programas que não favoreçam o debate e que privilegiem apenas a transmissão eficaz de um grande número de conhecimentos e informações não conseguem atingir esse objetivo maior. Na medida em que há, também, uma estreita relação entre os saberes docentes e a capacidade para problematizá-los e tomar decisões, não é possível imaginar que sem a retomada, construção e reconstrução de saberes (inclusive os seus significados) seja possível que os professores consigam reestruturar seus conceitos e representações, base para a postura crítica e o pensamento autônomo.

Ur (2009, p.4) propõe-nos uma figura para ilustrar o desenvolvimento profissional do docente, levando em conta as influências internas de seu processo reflexivo, assim como as externas, representadas por teorias e concepções abstratas. Tais considerações são de extrema importância para as ocorrências que foram notadas ao longo do curso observado. 
A figura busca apontar quatro ocorrências (vivências) distintas, que se autoalimentam, para o processo da formação docente com vistas à autonomia e ao desenvolvimento de uma prática reflexiva. Para cada uma dessas ocorrências há também fatores externos que não só permitem que elas ocorram, mas também as direcionam e impulsionam.

Para a autora, muitos cursos de Formação Docente enfatizam a teoria e poucos trabalham as práticas de sala de aula. Essa orientação, conforme já salientamos anteriormente, foi também seguida no início do curso observado, porém com um propósito: garantir base teórica específica (e que procurou ser consolidada ao longo do curso), em consonância com os objetivos do curso de Capacitação como um todo (que vislumbra uma prática reflexiva em sala de aula e o uso de um modelo comunicativo de ensino-aprendizagem de Inglês nas escolas da rede).

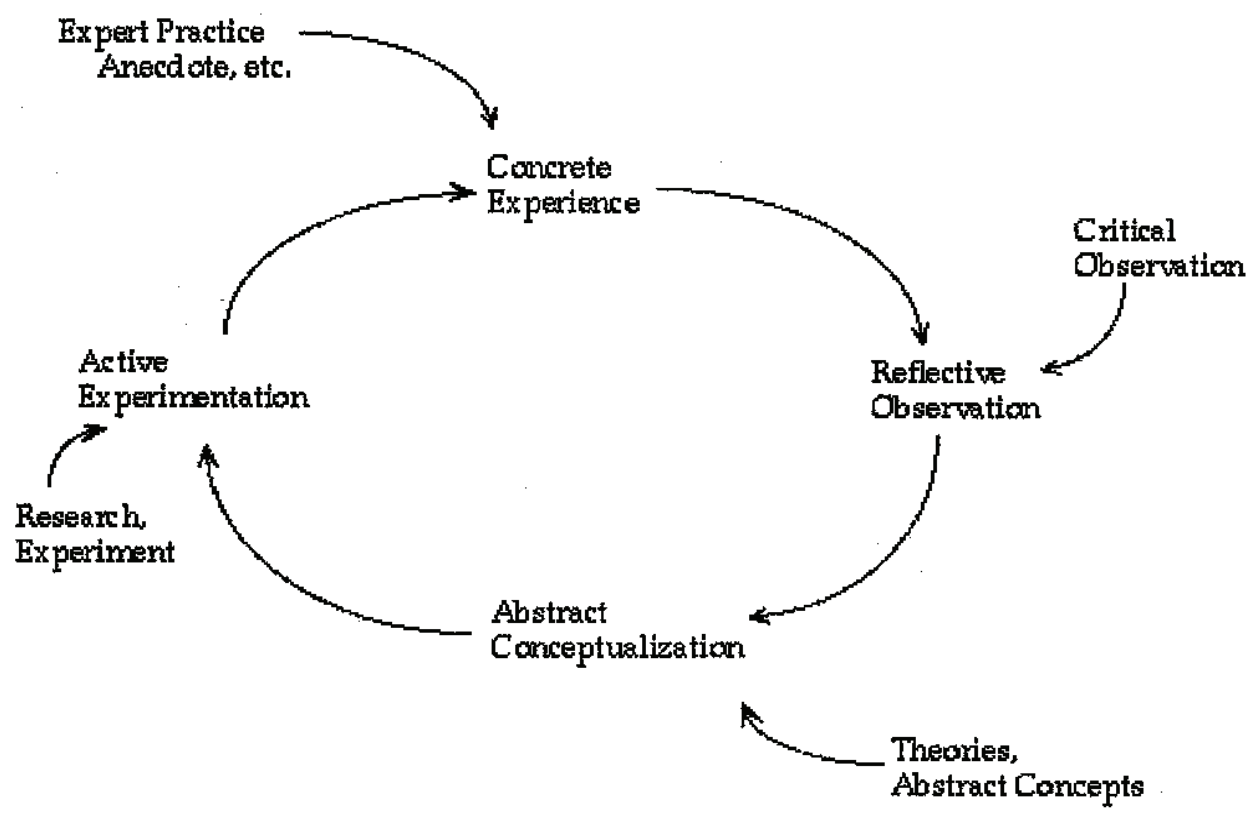

Figura 2: Proposta de Ur para o desenvolvimento profissional do professor.

Devemos mencionar, mais uma vez, a importância do aprimoramento linguístico do professor, oferecido nas aulas de Capacitação Linguística e o respaldo dado por esse curso para um melhor conhecimento do conteúdo que o professor vai ensinar. Também, nesse caso, a vivência de uma metodologia comunicativa e a possibilidade de reflexão, ainda que na condição de aluno, permite ao professor-aluno 
ampliar seu universo de indagações sobre o que vivencia no curso de Capacitação metodológica. Já o curso de Capacitação Linguística é uma "experiência concreta" vivenciada pelo professor e pode detonar, ainda que de outra maneira (porque é um outro olhar de professor como aluno) o processo indicado por Ur.

Um dos aspectos que mais mereceu consideração e relevância no curso de Capacitação relacionou-se ao trabalho do professor de LE, ciente da importância de planejar a aula para obter bons resultados. Considerações sobre a importância das três fases do planejamento, com atividades específicas para o ensino (fases pré, while and after) foram constantemente apresentadas, discutidas e criadas ao longo do curso, permitindo a esses professores-alunos observarem que um planejamento de aula cuidadoso pode auxiliar a lidar com o problema da indisciplina, que não desaparecerá, porém poderá ser minimizado. Os depoimentos dos professores em aula e em seus escritos demonstram o quão importante é para eles o aprendizado de seus alunos e quão felizes ficam quando conseguem desenvolver estratégias para obter a participação das turmas. Finalmente, outra mudança notável deu-se em função do trabalho colaborativo entre esses professores, que lhes serviu de incentivo a desenvolverem essa mesma prática com seus alunos, bem como a visão de projeto, que os encorajou no exercício da criatividade e da reflexão sobre as práticas em sala de aula, percebido na apresentação final dos trabalhos do curso.

A questão referente ao plano de aula leva-nos a considerar o que Aquino denomina de contrato pedagógico. O planejamento da aula mostra que o professor, dentro de seu domínio, tem um conteúdo específico em foco. Nesse planejamento, ainda, ele cita como vai desenvolver sua aula para que os alunos venham a aprender esse conteúdo, que lhes poderá ser de grande valia nas futuras carreiras (Aquino, 2000, p.54). Para o autor, três dimensões caracterizam o ofício docente: 1 . o que se ensina; 2. como se ensina, e 3. para que se ensina - fundamentos constantemente salientados em cursos de formação .

A pesquisadora gravou em vídeo trechos de apresentações feitas nos últimos dias do curso, assistidas por público externo interessado e representantes das Secretarias da Educação do Município e do Estado. Alguns segmentos de aulas, planejadas de acordo com o aprendido e discutido no curso, com recursos visuais e seguindo os passos determinados para a tarefa, foram apresentados pelos professoresalunos, que responderam a perguntas feitas pela platéia ouvinte. Foi no desenrolar de 
uma dessas apresentações que a pesquisadora ouviu o seguinte comentário de uma pessoa da audiência: "e são professores da rede pública..."

Esse olhar sobre as práticas de sala de aula e tomadas de decisão em relação ao que pode e deve ser feito em um determinado momento de ensino mostra que, pelo menos, o objetivo que Ariadne relata abaixo foi alcançado. Diz ela, na entrevista oral:

$\mathrm{Na}$ realidade, trabalhamos com a abordagem comunicativa porque acreditamos que esta seja a abordagem que vá ao encontro das necessidades dos dias de hoje, mais significativa no contexto deles. Mas não tem uma prescrição, a idéia é a de que eles reflitam, mesmo, sobre a prática e que possam criar as suas próprias, digamos, teorias.

E mesmo que o ponto de partida tenha sido um modelo dado para ser adaptado ou aplicado a outra situação, deu-se espaço para o exercício da reflexão, ainda que incipiente, conforme demonstraram os dados analisados. Lançou-se o caminho fundamental para a busca da autonomia: "Conceber o projeto de se tornar um ser autônomo já é uma manifestação de autonomia. A alienação total é não se pensar como sujeito capaz de autonomia, não se valorizar suficientemente para pensar e agir por si mesmo". (PERRENOUD, 2008, p.114).

Ao induzir postura e conduta reflexivas, o curso incentiva cada professoraluno (munido dos conhecimentos e vivências anteriores e adquiridas ao longo do curso) a "aprender com a experiência e refletir por si mesmo, sem ser prisioneiro do pensamento único ou das expectativas de seu meio. Esta é uma atitude e uma meta competência da qual dependem todas as outras.” (PERRENOUD, 2008, p.131) 


\title{
CAPÍTULO 4 - A ANÁLISE DOS DIÁRIOS E ENTREVISTAS: RESULTADOS
}

\author{
O aprendizado de uma Língua Estrangeira para mim soa como mágico, pois \\ é uma oportunidade de conhecer outra cultura, essa é a minha motivação \\ particular. O ensino deLíngua Estrangeira na escola publica é uma batalha \\ árdua, sem vencedores... \\ Professora Elisa/diário
}

Neste capítulo, analisaremos os registros nos diários dos professores-alunos, à luz das teorias anteriormente mencionadas no Capítulo 1. Detectamos um percurso na escrita dos diários, com três "configurações textuais", cada uma com diferentes características em relação à forma e aos temas tratados e, para revelar essa diferenciação, optamos por nomeá-las em função de tais características, chegando a três grandes "momentos de escrita" dos textos no diário: muro das lamentações, luz no final do túnel e indícios de reflexão. A análise será também complementada com os dados obtidos nas entrevistas.

\subsection{CONHECENDO UM POUCO MAIS AS CARACTERÍSTICAS DOS SUJEITOS PESQUISADOS}

Os professores-alunos, sujeitos desta pesquisa estão em diferentes fases de suas carreiras, porém, independentemente da idade e do tempo de exercício da profissão, participar do curso de Capacitação é para todos, sem exceção, um investimento, principalmente pessoal. Vale relembrar que esse curso tem valor muito pequeno na pontuação para ascensão na carreira, portanto, os professores que o concluem fazem-no porque podem e querem, sem maiores pretensões de valorização salarial - o meio ponto que recebem por esse certificado praticamente não provoca alteração nenhuma na sua condição profissional, do ponto de vista institucional. $\mathrm{O}$ valor, segundo eles mesmos, vem por conta de seu crescimento profissional, da ampliação do seu universo de conhecimento linguístico e pedagógico. Há inclusive, por parte deles, uma valorização do curso pelo aspecto "do acesso ou privilégio" de contato com uma instituição considerada de excelência acadêmica: nesse sentido, o que tem mais peso para 
eles é o do desenvolvimento e crescimento profissional e, para tal, vale o investimento, mesmo sem o "lucro monetário".

Apesar dessa "fase de investimento", nem todos se encaixam exatamente nas características do modelo proposto por Huberman (2000), em relação à idade e ao estágio em que se encontram, como poderemos notar a seguir, nos exemplos de dois casos analisados à luz do modelo de Huberman.

Iniciemos com o primeiro, que, de certo modo, confirma tal modelo, e as características do professor recém-formado. Diz ele que o professor começa sua carreira com um choque, o choque do real, ilustrado pelo tatear constante e pela indagação: "Será que eu aguento?" E se depara com a distância entre seus ideais e a realidade da sala de aula, a fragmentação do trabalho, as dificuldades com alunos que criam problemas, dificuldades com o material didático. Muitos autores, entre eles Fuller (1969), Field (1969) e Watts (1980) (apud NÓVOA, 2000, p.39) denominam essa de fase de sobrevivência ou do confronto inicial. Acompanha tal estágio do confronto inicial - para alguns profissionais, aliado a sentimentos de angústia e sofrimento -, um momento que Huberman denomina de descoberta, em que o entusiasmo inicial do profissional em ser professor, ter sua própria classe, pertencer a um quadro de professores é vivenciado pelo profissional iniciante na carreira. Desse modo, a iniciação profissional configura-se num movimento de "altos e baixos", com grande interferência no plano emocional do indivíduo.

Segundo resultados de pesquisas, diz Huberman (2000, p.39) que o aspecto da descoberta, do entusiasmo inicial permite aguentar o primeiro aspecto da sobrevivência, do choque, do confronto. No grupo de sujeitos da nossa pesquisa, pudemos observar sujeitosprofessores jovens que parecem estar exatamente nessa fase: uma recém-formada professora do grupo - Jaci - começara, por exemplo, a lecionar no Estado havia pouco tempo e mostrava entusiasmo em fazer o curso de Capacitação, apresentando um diário apenas com uma aula planejada, mas com observações em que revelava mobilização para a aprendizagem e grande entusiasmo em melhorar o seu trabalho docente. Jaci, na faixa dos vinte e cinco anos, demorou, no entanto, a escrever prontamente no diário; necessitando de mais tempo para colocar no papel suas considerações. Nossa observação dessa aluna, ao longo do curso de Capacitação, mostrou características de seu comportamento que, no nosso entender, ilustram o choque do real e o processo de descoberta e entusiasmo: ela ouvia mais do que falava, não se sentindo à vontade para relatar experiências em sala de aula. Paulatinamente, no decorrer do segundo semestre, começou a participar trazendo contribuições bastante motivadoras para o grupo. Um fato importante foi notar a interação de Jaci com colegas mais experientes em 
idade e vivência profissional, como se buscasse neles apoio - suporte para a "sobrevivência" no curso e no exercício docente e nas dificuldades dele decorrentes - e, ao mesmo tempo, inserção no grupo, em uma tentativa de "pertencimento" e de fazer parte do quadro representativo de profissionais.

Jaci nos procurou para entregar seu diário, apenas com uma aula planejada em detalhes e comentada. Esse "produto final" remete-nos às competências de Perrenoud, mais especificamente a de procurar "construir e planejar dispositivos e sequências didáticas" e "estabelecer laços com as teorias subjacentes às atividades de aprendizagem", ainda que com uma estreita relação com o modelo Craft, de Wallace, qual seja a tentativa de reprodução de um componente do ensino, mas com uma série de comentários sobre a sua execução e aplicação (um primeiro indício de reflexão sobre a ação). O fato é que, ao buscar aplicar as noções de planejamento de aula, Jaci seguiu exatamente o modelo que havia sido ensinado no curso de Capacitação: o planejamento e suas etapas - provavelmente, o primeiro a que teve acesso até então. Nota-se ainda sua dificuldade com o uso da língua inglesa, pois quando foi avaliada precisou começar do nível Básico 1 do curso de Capacitação Linguística. Tal fato, com certeza, remete-nos à questão da formação inicial e da qualificação docente. No entanto, dado seu caráter receptivo e atitudes de interesse e envolvimento, bem como sua percepção quanto ao próprio conhecimento limitado da língua, certamente sua participação no curso de Capacitação irá afetar-lhe a carreira de alguma maneira, motivando-a a dar continuidade à sua formação. De qualquer modo, o curso pode oferecer para Jaci um caráter impulsionador da carreira, para superação de um sentimento de "incapacidade" para o pleno exercício profissional.

Já, nosso segundo exemplo, Gary, em fase diferente de Jaci, contraria o modelo de Huberman. Por ser professor há mais tempo, bem mais velho e proficiente na língua, sentia-se mais à vontade para falar de suas aulas. Era o líder de grupo nas atividades, durante o curso, e tinha um entusiasmo típico de uma fase de ativismo, diversificação. Gary, que acabou recebendo bolsa para estudar nos EUA, no final do curso, deu mostras de que as fases propostas por Huberman em função da idade e do tempo de serviço nem sempre acontecem de acordo com o previsto no modelo: ele, professor mais velho e em idade na qual Huberman trataria como uma fase de desinvestimento, comportou-se com entusiasmo e interesse em aprender. Casos como o de Gary mostram que a história de vida dos professores leva-os a atitudes e comportamentos não classificáveis rigidamente. Vale ainda ressaltar que, no caso desse professor, temos outro dado que pode justificar seu entusiasmo: o início na carreira mais tardio do que os demais, uma vez que anteriormente trabalhou em outra atividade. Nesse 
sentido, a escolha pela docência foi bastante consciente e, desse modo, o investimento na carreira e o entusiasmo seriam decorrência natural dessa certeza a respeito da profissão escolhida. Nesse aspecto, Gary caracteriza-se como um profissional pertencente a uma fase de perene consolidação na carreira e de experimentação de novas ideias. Isso sem falar nos traços de personalidade e atitude, revelados em seu depoimento durante entrevista:

\begin{abstract}
Professor Gary:
No caso do noturno, com os colegiais, com o Ensino Médio, é um pouco mais fácil, é um pessoal um pouco mais adulto. Eu já estou na escola há algum tempo. Tenho, assim, uma penetração legal com eles, eles me têm em respeito, certo? Eu sou um cara que costuma brincar na hora certa, não sou um professor, apesar da enorme diferença que tem entre mim e eles? Eu levo a classe numa boa, num ambiente que eu acho legal.
\end{abstract}

Pesquisadora: Não tem nada a ver com a idade?

G: Não, nada disso.

Pesquisadora: Muito pelo contrário?

G: Muito pelo contrário. Tem professores mais jovens lá que são até mais sisudos.

Pesquisadora: Personalidade...

G: Exatamente, então isso me ajuda...

Vemos, portanto, nesse caso específico, que a idade tem efeito positivo na atuação do profissional, garantindo a ele equilíbrio para agir e, consequentemente, o respeito dos alunos. Gary mostra estar em um estágio de diversificação e de experimentação de novas ideias e forte tendência ao questionamento da rotina. Em seu diário, apresentou uma atividade diferente da tradicional, com a sinopse do filme Crash, na qual trabalhou compreensão e vocabulário, fazendo uso de estratégia diferenciada e atividade em duplas, uma proposta de aprendizagem colaborativa (ver Anexo 1). Além disso, Gary propõe para a classe a noção de “disciplina para o trabalho", o que lhe dá respaldo para retirar da sala dois alunos, com comportamento inadequado e que sequer haviam iniciado a tarefa proposta por ele (ver Anexo 1). Ao mesmo tempo em que toma decisões radicais quanto à manutenção da disciplina em sala de aula, justifica sua dificuldade em lidar com jovens em idade de puberdade, entre 14 e 15 anos. Questiona, também, a organização e a distribuição das aulas de Inglês, inseridas às sextas-feiras, no último horário. A fase da estabilização consiste em uma escolha subjetiva e em um ato administrativo (a nomeação oficial). A escolha da profissão de professor significa também uma renúncia a outras carreiras possíveis, podendo-se analisá-la psicanaliticamente como uma transição da adolescência para a vida adulta, em que os compromissos surgem 
mais carregados de consequências (HUBERMAN, 2000, p.40). Nessa fase, os professores afirmam-se frente aos colegas com mais experiência e sentem-se mais livres e emancipados.

De acordo com Huberman (2000, p.41), os percursos individuais parecem divergir a partir dessa fase correspondente à experimentação e à diversificação. Os professores experimentam o material didático, os modos de avaliação, as formações de grupos e sequências dos programas, e seriam os mais motivados e dinâmicos nas equipes pedagógicas e nas comissões de reforma; é a fase do desafio, explicada por Cooper (1982 apud NÓVOA, 2000, p.42): "Durante essa fase, o professor busca novos estímulos, novas ideias, novos compromissos. Sente a necessidade de se comprometer com projetos de algum significado e envergadura: procura mobilizar esse sentimento, acabado de adquirir, de eficácia e competência".

Verificamos, no depoimento a seguir, a mobilização de uma professora para o projeto pedido como trabalho de avaliação, no curso de Capacitação Metodológica. Percebemos, inclusive, o uso de termos em inglês aprendidos no curso, tais como: warm up, performance, listening task, entre outros.

Entrei na $6^{\mathrm{a}} \mathrm{C}$ e cumprimentei os alunos. Falei que iríamos trabalhar o listening task. Comecei com o nursery rhyme Hickory Dickory Dock, eles copiaram da lousa e fizemos a performance do pêndulo do relógio, o rato subindo o pêndulo, etc. Como eles já haviam aprendido as horas, o nursery ficou como warm up. Em seguida, coloquei uma tabela para eles completarem, de acordo com o listening (CD Intro, de Jack Richards). Eles comentaram que gostaram da atividade, porque era do tipo filling the blanks. Corrigimos depois (sempre valendo ponto positivo!). Esta é uma classe que estou utilizando como classe-projeto para o portfólio do curso de Capacitação (Professora Melissa / diário).

A fase do questionamento tem muitos aspectos. Para alguns autores, a monotonia da vida cotidiana, ano após ano, acrescida das dificuldades para o desenvolvimento do trabalho provoca esse questionamento. É o que se depreende dos escritos a seguir:

Em resumo, a escola não tem sala de vídeo, não tem como levá-los à sala de Informática e o que me resta é adaptar as atividades em sala de aula mesmo. As turmas são numerosas, de 38 a 40 alunos, eles conversam demais e é difícil prender a atenção deles, mas tem um ponto positivo: os alunos não desrespeitam os professores e o respaldo da equipe técnica é satisfatório (Professora Sonia / diário).

Outros autores veem tal fase com o desencanto subsequente aos fracassos experimentados. Segundo Huberman (2000, p.43), há indicações de que o questionamento é sentido diferentemente por homens e mulheres: eles questionam mais cedo do que elas. Segundo Prick (1986 apud HUBERMAN, 2000, p.43), o período mais acentuado da crise, nos 
homens, começa aos 36 anos e pode durar até os 55, parecendo associado à questão de um plano de carreira e de vida financeira; já, para as mulheres, esse momento chega mais tarde, aos 39 anos, e dura menos tempo, até os 45, estando mais associado aos aspectos desagradáveis das tarefas e condições do trabalho. Porém, independentemente do sexo, nossa pesquisa mostra que a grande maioria dos professores tem o perfil do sujeito que questiona, reclama e desilude-se. Um deles chegou, em seu diário, a indagar à pesquisadora o que ela queria com ele e chegou a afirmar ser um fracasso. Alguns outros desses professores mencionam percentagens de fracasso e desilusão. Alguns exemplos:

Com 16 anos de magistério, [só posso pensar que] ou você está sendo testada para ver até onde vai, ou isso é um problema de $7^{\mathrm{a}}$ séries. Tenho 12 classes $\left(6^{\mathrm{a}}, 7^{\mathrm{a}}\right.$ e $\left.8^{\mathrm{a}}\right)$ e são as 7 as que mais me dão problemas. Essa escola é considerada boa pela comunidade, mas tem muitos problemas disciplinares.

A escola faz o possível e o professor também, mas o sistema não funciona (Professora Melissa/diário).

I really don't know what you want me to write. And also if I'm the person you should be contacting. I have started teaching 5 years ago and thinking seriously in giving up. I'm sick and tired of trying to teach and getting nothing. From 40 students, about 6 are interested and I feel I'm a failure because I'm not able to get their interest .

Realmente não sei o que você quer que eu escreva. E se sou a pessoa que você deveria estar contatando. Comecei a lecionar 5 anos atrás e penso seriamente em desistir. Estou cansada de tentar ensinar e nada conseguir. De 40 alunos, cerca de seis estão interessados, e sinto que sou uma negação, pois não sou capaz de conseguir interessar os alunos (Professora Virna/diário, tradução nossa).

Professor Julian: É o seguinte. O que eu vejo, uma das maiores dificuldades de se ensinar a [Língua] Inglesa na escola pública é a questão da falta de material de apoio, no caso, o livro didático, para o aluno. Já estou há doze anos na rede e o único livro que tentei trabalhar foi um livro adotado. E que nem todos os alunos conseguiram adquirir, por questões financeiras, recursos próprios de que eles não disponibilizavam... Até mesmo o único dicionário que podia acompanhar, que podia ajudá-los, é difícil adquirir. Apesar de que, neste ano, já está bem melhor, porque no ano passado, com o projeto "Ler e Escrever", as escolas receberam um kit, um kit de inglês que corresponde a apenas dez volumes de cada livro. E alguns dicionários também chegaram às escolas. Isso é o que tem facilitado. Mesmo com uma pequena quantidade de exemplares é o que tem facilitado nosso trabalho, ainda minimizando aquelas questões relacionadas ao material de apoio.

Pesquisadora: Não tem sequência aquela aula? De uma aula para outra?

PJ: Ah, sim, a sequência a gente elabora em cima do nosso plano. E também, revendo a questão da Proposta Curricular, nós temos pressupostos da Proposta e temos que... procuramos atender um pouco aquilo que foi traçado e foi determinado pela Secretaria da Educação. Claro que, em consonância com o trabalho do professor. Foi passado para as escolas, nós analisamos e fizemos algumas alterações, porque víamos que havia coisas, 
digamos, que não tínhamos condições de cumprir, né? Que inviabilizavam todo o trabalho. Por exemplo, trabalhar na sala de Informática, visto que o professor de Informática é um e o professor de Língua Inglesa é outro... Ou seja, são aulas diferentes, não é como nos outros anos, em que o professor trabalhava junto com o professor de Informática, levava seus alunos e, lá na sala, esse professor auxiliava a fazer as atividades, desenvolver atividades com os alunos, o que eu achava mais interessante do que hoje. Porque, muitas vezes, o professor de Informática não tem esse conhecimento da Língua Inglesa e como é que vai orientar esses alunos? Eu sei que tem uma infinidade de coisas que se podem aproveitar, que se podem desenvolver na Informática. Mas ainda vejo que essa deficiência...

Pesquisadora: E quais são as propostas que vocês recebem? Os objetivos que vocês têm que alcançar com essas aulas? Tem alguma coisa clara a esse respeito?

PJ: Está estampado. Passei em frente à banca de jornal, vindo pra cá. E, olha, tem sim, tem a Proposta. É bem elaborada, apesar de estar um pouco distante da realidade do nosso aluno, porque, o ensino brasileiro, não são só os alunos da rede pública, mas em todo ensino brasileiro vemos que tem uma defasagem muito grande, inclusive hoje eu vi, na manchete do jornal, que a escola de Primeiro Mundo, no Brasil, o governo do estado diz que só vai ser para 2030, ou seja, até 2030, eu já estarei aposentado, não vou ver essa escola e gostaria de trabalhar nessa escola. Não observei em qual jornal, mas observei isso, daí fiz as minhas contas. Quer dizer que eu não vou participar dessa escola de Primeiro Mundo aqui no Brasil, como trabalhador, mas a gente espera que muitas coisas possam melhorar. Principalmente no tocante ao ensino da Língua Inglesa. Que é uma língua universal e que todos têm que ter esse acesso para conhecer novas culturas, para o mercado de trabalho, para as exigências que nós temos no dia a dia (Professor Julian/entrevista).

A Fase do questionamento corresponde em nossos registros ao denominado muro das lamentações. Observamos que queixas e dificuldades, tidas como insolúveis (porque não fazem parte do universo de atuação do professor, segundo os informantes) estão presentes em todos os diários e indagamos o significado de tantas lamúrias nesses dados coletados. Elas são de toda ordem, mas em geral, no entender dos professores, os grandes responsáveis são os alunos e o sistema escolar. Algumas indagações surgiram, frente a tantas reclamações sobre os alunos e as escolas. Questionamos essa recorrência nos registros, hipotetizando se esse muro das lamentações mascara algum outro problema que precisaria de maior análise. Os dados nos mostram que as queixas dos professores surgem como resultado natural de problemas reais que eles enfrentam (o sistema, as condições físicas das escolas, entre outros) e de problemas que os professores deixam de considerar (os alunos e as aulas, especialmente) mas pelos quais eles têm responsabilidade, embora não se sintam em condições de enfrentálos. Daí priorizarem os "problemas" que estão fora do seu domínio, como se fossem os 
grandes responsáveis por todas as ocorrências mal-sucedidas. Vejamos a seguir depoimentos que ilustram ainda mais esse quadro das lamentações:

Os procedimentos para as atividades em LE são difíceis, pelo tempo: são 2 aulas de 45 minutos na semana, em dois dias de 1 aula em cada. Alguns alunos se interessam por aprender, outros são dispersos, acham que a LE não serve para nada. Uma aprendizagem focada na comunicação é impossível, em escola municipal; os alunos adoram conversar, brincar, tudo menos estudar; não têm o hábito, parece que não têm objetivo para o futuro (Professora Sonia/diário).

Alunos do fundamental II, ESPECIFICAMENTE DA $8^{\mathrm{a}}$ SÉRIE (minha turma), não se interessam muito pela língua inglesa. Eles a acham muito difícil e acreditam que não precisarão aprender no futuro. Poucos são os interessados e que têm noção ou já sabem. A turma é totalmente (de modo geral) desinteressada (Professora Flora/diário).

A maior dificuldade de ensinar a matéria de Inglês é o desinteresse, a falta de compromisso dos alunos com os estudos, mesmo sabendo que é necessário saber o básico para um bom emprego ou para seu aperfeiçoamento extracurricular.

Nós ficamos tentando achar uma estratégia para atrair o interesse pela matéria. Quando traçamos estratégias e métodos para as nossas aulas, vemos que não atingimos $100 \%$ e sim $30 \%$ dos alunos, e é aí que nos decepcionamos pelo nosso fracasso ... mas nada como uma aula após a outra (Professora Sabrina/diário).

Eu trabalho com uma turma de $5^{\text {a }}$ série, com 38 alunos frequentes. É difícil, pois é uma turma muito falante, sem limites. Já tentei apresentar vários trabalhos, mas sem retorno, pois eles dizem que não gostam de inglês. São 2 aulas semanais (Professora Lydia/diário).

Abriremos aqui um pequeno parêntese para chamar a atenção para o problema que surge como bode expiatório e como responsável, segundo os professores, pelo insucesso do ensino: os alunos. Voltaremos a ele mais adiante.

Além disso, nos registros que compõem esse primeiro momento notamos a presença da descrença dos professores em relação às possibilidades de desenvolvimento de um trabalho que resulte em efetivo aprendizado da língua, resultante de várias tentativas frustradas. Desse modo, fundamentam a crença de que não adianta reagir, pois não há interesse pelo que ensinam. Como se o "despertar o interesse dos alunos" não fizesse parte das suas responsabilidades docentes... Instaura-se, portanto, um grande conflito interno em que a vontade de acertar deixa de existir, deixando prevalecer o acúmulo de frustrações, gerando mais ansiedade e desilusões.

Huberman argumenta que se pode alcançar a serenidade por vias distintas, mas frequentemente os professores a percebem na sequência da fase do questionamento, entre os 45 e 55 anos. Há uma proporção de menos ambição e investimento e maior confiança e 
serenidade. A atitude do professor muda, ficando mais tolerante e mais espontânea, e surge um distanciamento afetivo frente aos alunos, por pertencerem, nesta etapa, a gerações diferentes.

Queixas relacionadas ao "choque de gerações" foram observadas em alguns indivíduos deste Estudo de Caso, especialmente naqueles que sentem dificuldade em trabalhar com alunos adolescentes. No entanto, poucos (Gary é uma das exceções) demonstraram tolerância e serenidade suficientes para superar essas diferenças. Muito pelo contrário, referências às antigas $5^{\mathrm{a}}$ e $7^{\mathrm{a}}$ séries (atualmente $6^{\circ}$ e $8^{\circ}$ anos) do Ensino Fundamental, tidas como problemáticas, ocorreram por diversas vezes nos discursos escritos dos professores.

Apesar de, no grupo, não termos professores acima de 50 anos, a atitude inicial dos participantes desta pesquisa assemelha-se muito à descrita por Huberman.

Segundo o autor, professores entre 50 e 60 anos, em número considerável, queixam-se da evolução dos alunos que são mais indisciplinados, menos motivados. Queixam-se da atitude negativa para com o ensino, da política educacional, dos colegas mais jovens.

Portanto, levando em conta os diários, a grande maioria dos professores analisados parecem estar nessa fase, apesar de não estarem nessa faixa de idade. Porém Huberman afirma que as coisas não são tão simples. Diz o autor (op.cit., 2000, p.45) que os professores mais conservadores chegam lá mais cedo e por vários caminhos (um questionamento mais prolongado, na sequência de uma reforma estrutural que fracassa, ou face a uma reforma a que se opõem, por exemplo). O autor concorda com Hultsch e Piemons (1972 apud HUBERMAN, 2000, p.46) e diz que não se pode agrupar esses professores, sem primeiro estudar seus antecedentes, isto é, sua história pessoal e a história de seu meio. Se levarmos em conta os dados que obtivemos no início da escrita dos diários e essa última afirmação dos autores, diríamos que todos, sem exceção, apresentam-se como "indivíduos desiludidos prematuramente" e que provavelmente essa condição seja causada por entraves relacionados ao meio (o sistema, as escolas, o convívio com os alunos, entre outros) ou às suas histórias de vida pessoal (condições de sobrevivência, de status cultural e social, entre outros).

No grupo de sujeitos-professores pesquisados, observamos um sujeito que decide desinvestir na carreira de professor do Estado, alegando ter pedido exoneração do cargo. A questão, nesse caso, leva-nos ao porquê do interesse pelo curso de Formação, em havendo o desinteresse pela vida profissional. 
Sou professora desde que iniciei meu curso de Letras - muitas vezes sem o registro na carteira de trabalho - uma brecha utilizada pelas escolas particulares. Eu me formei professora de Língua Inglesa mais pela paixão pela língua propriamente dita - desde o colégio.

O aprendizado de uma língua estrangeira, para mim, soa como mágico, pois é uma oportunidade de conhecer outra cultura, essa é minha motivação particular.

O ensino de Língua Estrangeira na escola pública é uma batalha árdua, sem vencedores. Hoje esta é minha posição, meu ponto de vista. Entretanto, enquanto profissional, dou o melhor de mim para realizar meu trabalho dentro de sala de aula e, atualmente, através dos cursos de formação de metodologia de ensino e de aspectos linguísticos, tenho realizado boas aulas que levam ao aprendizado.

Infelizmente, e essa é uma angústia de muitos colegas, a qualidade de nossas aulas é restrita a algumas turmas. O grande empecilho é o grande número de turmas que cada professor deve assumir. Esse foi um dos motivos pelos quais me exonerei da rede estadual de ensino. A outra dificuldade é o número de alunos por turma e o número reduzido de aulas semanais (Professora Elisa/diário).

As observações da professora Elisa revelam que, muito embora ela considere importante a responsabilidade de desenvolvimento e de atuação profissionais (e parece cumpri-la, de fato), as condições de trabalho não lhe são favoráveis para cumprir o que almeja. Sua decisão pelo abandono parece não estar relacionada à profissão e sim ao exercício profissional nas condições de precariedade em que tem atuado. No entanto, o interesse pela continuidade de sua formação por meio de cursos desse tipo pode também indicar um investimento na profissão para algo diferente, talvez como porta de entrada para outros locais de trabalho (rede particular ou escolas de idiomas, por exemplo).

\subsection{OS ESCRITOS E AS FALAS DOS PROFESSORES: UMA VISÃO PANORÂMICA}

Passada a fase das queixas, os efeitos do curso de Capacitação no discurso dos professores-alunos da rede começaram a emergir. O foco passou a ser outro, o que nos permitiu caracterizar os escritos (diários) e as falas (entrevistas), agrupando-os a partir das suas diferenças em relação aos temas tratados e à forma com que foram apresentados. Nossa preocupação não foi distingui-los fazendo uso de referencial teórico de Análise de Discurso, mas sim, agrupá-los pelas suas principais características em relação a "o que” era apresentado e "como" eram apresentadas as informações neles contidas. 
Os escritos revelaram três momentos distintos, processados durante a leitura e análise dos diários e das entrevistas. O primeiro momento constituiu-se desse Momento de queixas e desilusões, descrito, em parte, no item anterior deste capítulo. Os outros dois são representativos, no nosso entender, do que ocorreu no curso de Capacitação e da sua organização, uma vez que encontramos vários indícios que "comprovam” essa relação..

Os três momentos, bem como os registros principais dos professores, estão representados na tabela 1. Optamos por utilizar três diferentes tonalidades da cor azul para indicar cada um deles: azul bem claro e esverdeado para o momento por nós denominado muro das lamentações; azul menos claro para o momento por nós denominado luz no final do túnel e azul mais forte para o momento por nós denominado indícios de reflexão. Para a elaboração da tabela, inserimos as afirmações que melhor resumiam aquelas apresentadas nos textos. Cada texto, escrito no período de 2 a 3 semanas (período que normalmente os professores levaram para escrever nos diários as suas considerações e foi indicado pela letra M, seguido de números que indicam cada um desses períodos. Portanto, M1 significa uma ocorrência (um texto encaminhado no diário, acompanhado ou não de entrevista) em um período de tempo.

Optamos, também, por indicar cada professor-aluno por $\mathrm{P}$, seguido de número. Assim, P1 refere-se ao informante 1; P2 ao informante 2 e assim sucessivamente. 


\begin{tabular}{|c|c|c|c|c|c|c|c|c|c|c|c|c|c|}
\hline & \multicolumn{13}{|c|}{ MOMENTOS } \\
\hline PROF. & M1 & M2 & M3 & M4 & M5 & M6 & M7 & M8 & $\begin{array}{c}\text { M9 } \\
\text { início de } \\
\text { mudanças }\end{array}$ & $\begin{array}{c}\text { M10 } \\
\text { mudanças }\end{array}$ & M11 & M12 & M13 \\
\hline P1 & $\begin{array}{l}\text { indisciplina, } \\
\text { problemas } \\
\text { aprendizado }\end{array}$ & $\begin{array}{l}\text { indisciplina, } \\
\text { dificuldade } \\
\text { aprendizado }\end{array}$ & $\begin{array}{l}\text { disciplina } \\
\text { controlada, } \\
\text { filmes }\end{array}$ & $\begin{array}{l}\text { Indisciplina, } \\
\text { falta } \\
\text { esperança }\end{array}$ & $\begin{array}{l}\text { falta de } \\
\text { recursos } \\
\text { didáticos }\end{array}$ & $\begin{array}{l}\text { disciplina com } \\
\text { esforço do } \\
\text { professor }\end{array}$ & $\begin{array}{l}\text { interesse } \\
\text { atividades em } \\
\text { inglês }\end{array}$ & $\begin{array}{c}\text { disciplina sob } \\
\text { controle, } \\
\text { reunião pais }\end{array}$ & $\begin{array}{l}\text { aula bem } \\
\text { sucedida e } \\
\text { interesse }\end{array}$ & $\begin{array}{l}\text { aulas bem } \\
\text { planejadas. } \\
\text { sucesso }\end{array}$ & $\begin{array}{l}\text { pré, while e } \\
\text { post. Indisc. } \\
\text { controlada. }\end{array}$ & $\begin{array}{l}\text { realizações } \\
\text { e sucesso } \\
\text { em aulas dif }\end{array}$ & aula \\
\hline P2 & $\begin{array}{l}\text { falta de } \\
\text { material }\end{array}$ & $\begin{array}{l}\text { utili material } \\
\text { enviado }\end{array}$ & $\begin{array}{l}\text { dificuldade } \\
\text { memoriz. }\end{array}$ & $\begin{array}{l}\text { dificuldade } \\
\text { memoriz. }\end{array}$ & $\begin{array}{l}\text { dificuldade } \\
\text { aprendizado }\end{array}$ & & & & & & & planej & aula \\
\hline P3 & $\begin{array}{l}\text { indisciplina, } \\
\text { dif.aprendiz }\end{array}$ & $\begin{array}{l}\text { indisciplina, } \\
\text { dif. aprendiz }\end{array}$ & indisciplina & $\begin{array}{l}\text { dificuldade } \\
\text { Ab daescrita }\end{array}$ & Inter. música & & & & & & & planej & aula \\
\hline P4 & $\begin{array}{l}\text { Classesnum.e } \\
n^{\circ} \text { aulas }\end{array}$ & & Reg.oral & & Reg.oral & & & & & Reg.oral & & planej & aula \\
\hline P5 & indisciplina & & & & & & & & & & & planej & aula \\
\hline P6 & $\begin{array}{c}\text { Indisciplina } \\
\text { aulas } \\
\text { significativas }\end{array}$ & Reg.oral & & & & & & & Reg.oral & & & planej & aula \\
\hline P7 & $\begin{array}{l}\text { recurs., } \\
\text { indisciplina, } \\
\text { tradução, }\end{array}$ & & & Reg.oral & & & & Reg.oral & & & & planej & aula \\
\hline P8 & $\begin{array}{c}\text { Alunos } \\
\text { indisciplin. }\end{array}$ & & & & & & & & & & & planej & aula \\
\hline P9 & $\begin{array}{c}\text { alunos } \\
\text { desinteres. }\end{array}$ & & & & & Reg.oral & & & & & & planej & aula \\
\hline P10 & indisciplina & & & & & & & & & & & planej & aula \\
\hline P11 & $\begin{array}{c}\text { não rel } \\
\text { probl.inovaç. }\end{array}$ & & & & & & & & & Reg.oral & & planej & aula \\
\hline P12 & indisciplina & & & & & & & Reg.oral & & & & planej & aula \\
\hline P13 & $\begin{array}{l}\text { dificuldades } \\
\text { aprendizado }\end{array}$ & $\begin{array}{c}\text { jogos } \\
\text { apreciados }\end{array}$ & $\begin{array}{l}\text { professora } \\
\text { antenada }\end{array}$ & $\begin{array}{l}\text { dificuldades } \\
\text { aprendizado }\end{array}$ & & & & & & & & planej & aula \\
\hline P14 & $\begin{array}{l}\text { Sit.constranalu } \\
\text { deficient }\end{array}$ & $\begin{array}{l}\text { desistência do } \\
\text { curso }\end{array}$ & & & & & & & & & & & \\
\hline P15 & $\begin{array}{l}\text { desinteressedi } \\
\text { ficuldades } \\
\text { aprendizado }\end{array}$ & indisciplina & indisciplina & $\begin{array}{l}\text { Interesse em } \\
\text { desenho }\end{array}$ & $\begin{array}{l}\text { dificuldades } \\
\text { aprendizado } \\
\text { interesse } \mathrm{m} \text {. }\end{array}$ & $\begin{array}{l}\text { maiscooperaat } \\
\text { ividades orais }\end{array}$ & & & & & & planej & aula \\
\hline P16 & $\begin{array}{l}\text { desinteresse } \\
\text { difaprendiz }\end{array}$ & Reg.oral & & & & & & & & & & planej & aula \\
\hline P17 & $\begin{array}{l}\text { Reg. metade } \\
\text { do curso }\end{array}$ & & & & & $\begin{array}{l}\text { planejam. de } \\
\text { aula }\end{array}$ & $\begin{array}{l}\text { Al.comport. } \\
\text { interessados } \\
\text { Realiz tarefa }\end{array}$ & $\begin{array}{c}\text { leitura, } \\
\text { tradução e } \\
\text { reescrita }\end{array}$ & & & & planej & aula \\
\hline P18 & $\begin{array}{c}\text { falta material } \\
\text { didático }\end{array}$ & $\begin{array}{l}\text { Bom result } \\
\text { provas }\end{array}$ & Memorizaç/ & & & & & & $\begin{array}{c}\text { professor } \\
\text { mostramud/ }\end{array}$ & $\begin{array}{l}\text { envio fotos } \\
\text { Halloween }\end{array}$ & $\begin{array}{c}\text { planejam. de } \\
\text { aula }\end{array}$ & planej & aula \\
\hline P19 & $\begin{array}{l}\text { recusou-se a } \\
\text { escrever }\end{array}$ & & & & & & & & & & & planej & aula \\
\hline P20 & $\begin{array}{l}\text { indisciplina, } \\
\text { dif.aprendiz }\end{array}$ & & Reg.oral & & Reg.oral & & Reg.oral & & Reg.oral & & & planej & aula \\
\hline P21 & $\begin{array}{c}\text { falta material } \\
\text { didático }\end{array}$ & & & & & & & & & & & planej & aula \\
\hline P22 & $\begin{array}{l}\text { recusou-se a } \\
\text { escrever }\end{array}$ & & & & & & & & & & & planej & aula \\
\hline
\end{tabular}

Tabela 1: Três momentos de análises. 
Metade dos professores entregou apenas 2 textos escritos, um no início e outro no final do curso, o que não nos possibilitou a análise em relação ao percurso desses professores ao longo do curso. Outros entregaram 4 ou 5 textos, o que nos deu apenas uma ideia sobre o percurso. Mas, uma das professoras (P1), entregou-nos seu diário completo, com 16 textos, o que nos possibilitou uma análise mais centrada nesse caso, estabelecendo-se relações entre o que foi relatado no seu texto e a trajetória do curso. Apesar das limitações advindas do pequeno número de textos nos diários de boa parte dos informantes, buscamos proceder à análise do que foi escrito por todos, para apresentá-la de forma mais geral e nos debruçarmos, então, em analisar mais detalhadamente os textos da informante P1.

\subsection{1 "Muro das lamentações": era uma vez....}

Observamos, nos espaços azul-claros da planilha, o relato dos professores sobre fatores externos ao logos pedagógico que impedem sua prática. São queixas relativas a questões de indisciplina, falta de interesse, dificuldades de aprendizagem, falta de recursos, classes numerosas, conversas paralelas. Há, como já observamos anteriormente, um distanciamento entre o professor e os causadores de problemas: os alunos, a escola, o sistema. O professor sente-se vítima de dificuldades que seriam alheias a ele.

A figura 3 busca representar os problemas que, de acordo com os relatos dos professores, desencadeiam a indisciplina, considerada pela maioria como uma das maiores dificuldades para o trabalho docente. 


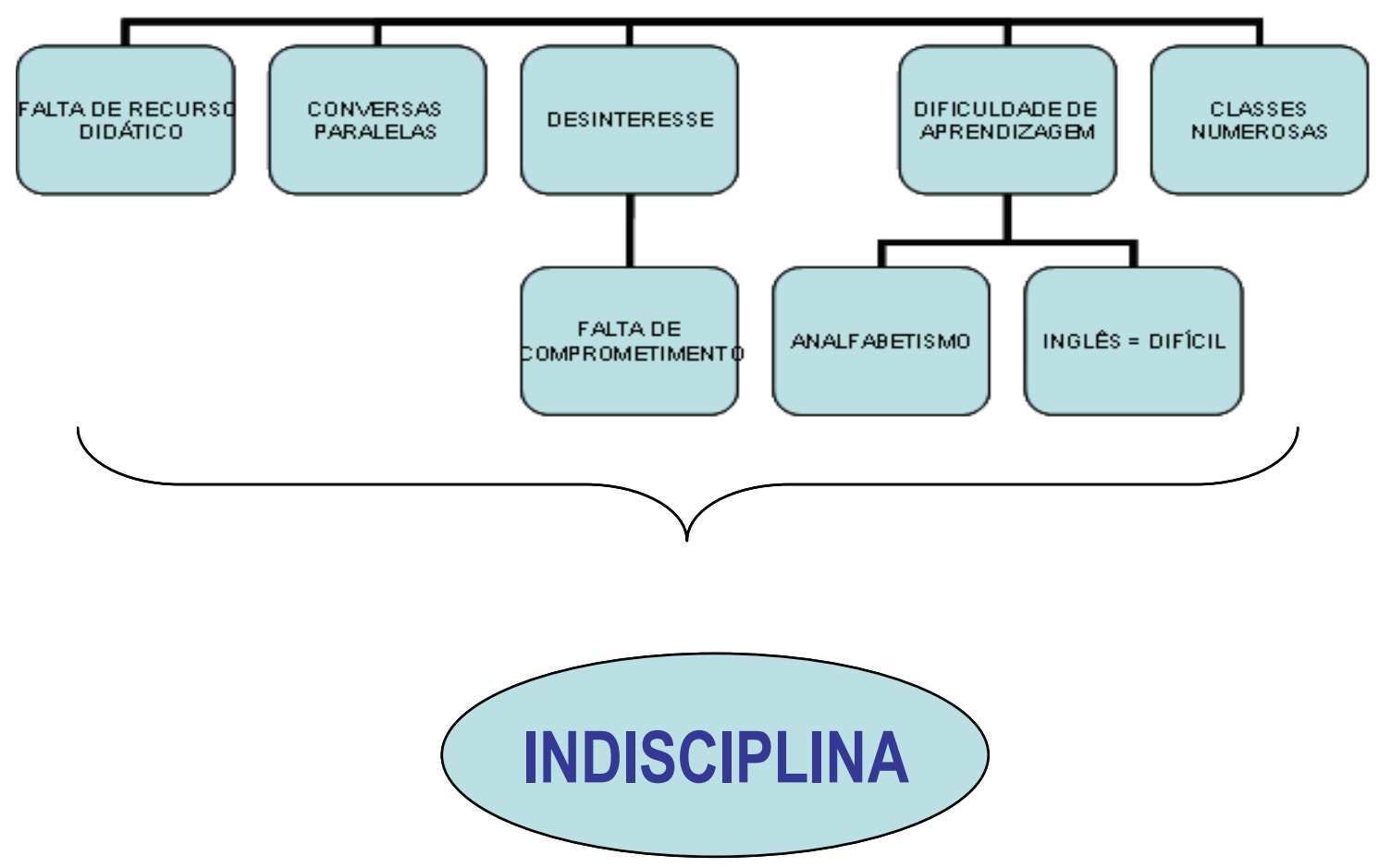

Figura 3: Problemas desencadeadores de indisciplina.

O gráfico 1, por sua vez, mostra-nos a frequência com que manifestam-se os motivos para a indisciplina.

FREQUÊNCIA DE MOTIVOS PARA A INDISCIPLNA

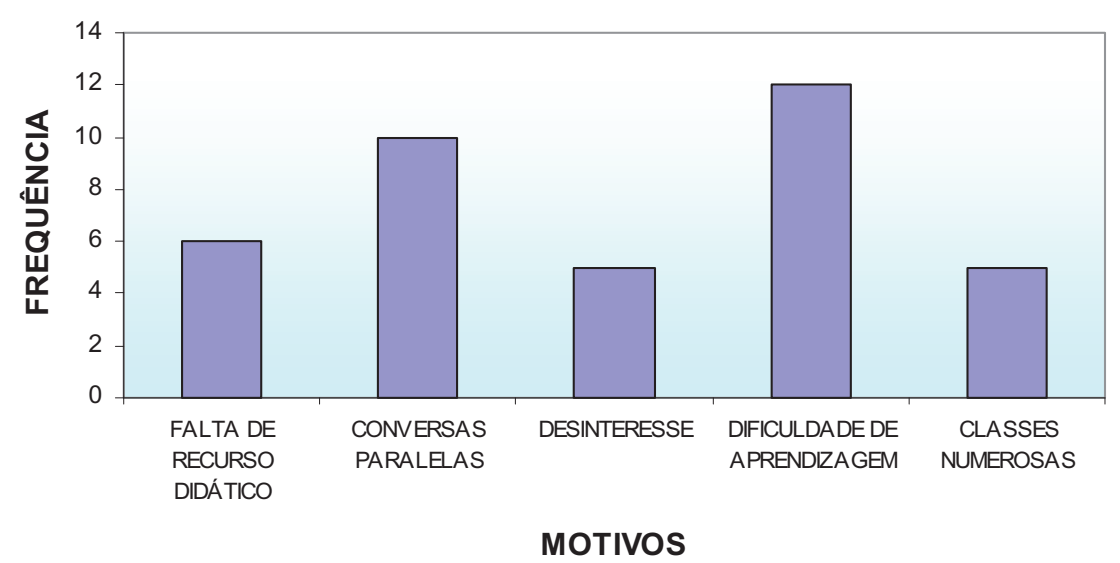

Gráfico 1: Frequência dos motivos desencadeadores de indisciplina. 
Entre as razões atribuídas à indisciplina, as dificuldades de aprendizagem vêm em primeiro lugar, seguidas pelas conversas paralelas e pela falta de recurso didático. Desinteresse e classes numerosas encontram-se, ambas, no mesmo patamar.

Nos registros dos professores-alunos, observamos aqueles que correspondem ao que Aquino Groppa (1998, p. $3^{1}$ ) denomina de preconceitos, “falsos conceitos e outras tantas justificativas para o fracasso e exclusão escolar". Diz-nos o autor que hipóteses explicativas da indisciplina por parte dos professores precisam ser repensadas. As hipóteses explicativas para a indisciplina, apresentadas nos registros analisados, ilustram os preconceitos indicados pelo autor e indicam também aspectos relacionados aos motivos dessa ocorrência, que buscam reforçar a condição de "vítima" e de "carente", assumida pelos professores.

Alguns registros, como veremos adiante, indicam vários dos falsos conceitos presentes no profissional de ensino, bem como sua visão em relação ao mundo que o cerca, e apontam, inclusive, para uma das hipóteses explicativas levantada por Aquino Groppa: o aluno “desrespeitador". Eis um exemplo:

Eu falei diversas vezes para um aluno: "Rafael, presta atenção! Deixa a bolsa da Jéssica aí!" Mas ele ignorou e sequer abriu o caderno, pra começar a trabalhar. Mas o pior foi que, quando comecei a explicar, ele começou a cantar junto. Não tive dúvidas, mandei para fora...

[...] Levei-o à diretoria e ele levou 2 dias de suspensão. Não era a primeira vez que aprontava e o pai já havia sido chamado várias vezes. Ele é de Codó, no Maranhão. A mãe o abandonou e ele diz que a odeia; uma única vez em que ele foi visitá-la, ela viajou para Brasília. O pior é que ele desestrutura toda sala!

A cada semana uma surpresa! Com 16 anos de magistério, (só posso pensar que) ou você está sendo testada para ver até onde você vai, ou isso é um problema de 7as séries. Tenho 12 classes ( 6as, 7as e 8as) e são as 7as que mais me dão problemas. Esta escola é considerada boa pela comunidade, mas tem muitos problemas disciplinares.

Já li alguns livros sobre disciplina, mas não há receita: uns falam que o professor não entra sozinho na sala, mas sim junto com o diretor, o coordenador, que é um trabalho coletivo; mas o sistema é que não funciona! Alunos analfabetos são os que são indisciplinados, têm problemas familiares etc etc. O ECA - Estatuto da Criança e do Adolescente - e o Conselho Tutelar são inúteis (Professora Melissa/diário).

Outros registros indicam atitudes tomadas pelos professores em relação à indisciplina e tentativas para controlá-la:

Tem que ter muita paciência para dar aula no Ensino Fundamental. Eu entro na sala e espero até que eles fiquem quietos, para eu falar (Professora Roxane/diário).

\footnotetext{
${ }^{1}$ Disponível em: www.scielo.br . Acesso em: 4 jan 2010.
} 
I waste a great deal of my classes trying to solve small conflict, such as: "she showed the finger", "she cut my hair", "he spanked me" "she throwed the paper ball she said I am a... BUT due to because of the mess, I gave up. At least I tried.

Perco muito tempo de aula tentando resolver conflitos pequenos como: ela me mostrou o dedo, ela cortou meu cabelo, ele me bateu, ela jogou uma bola de papel, ela disse que eu sou... Mas devido à bagunça eu desisto. Pelo menos, tentei (Professora Virna/diário, tradução nossa).

Há registros que também se enquadram na hipótese explicativa de Aquino Groppa (op.cit) denominada $O$ aluno sem limites.

Nessa mesma classe ( $\left.7^{\mathrm{a}} \mathrm{E}\right)$, fiquei esperando um tempo fora da sala porque, como a sala é do lado de fora do prédio principal e, na troca de aula, eles aproveitam para fechar a porta e deixar o professor para fora. Fiquei um tempo esperando abrirem e, como não abriram, pedi a uma aluna que também ficara fora para buscar a chave. Falei para eles que quem perde são eles; eu ganho do mesmo jeito. Já deixaram a mim e a professora de Ciências para fora, não sei se alguém mais.

Então, durante a aula, começam a cantar uma canção funk, falando sobre drogas. Falei que esse tipo de canção era "apologia ao crime" e, como toda vez que eu virava para a lousa, eles começavam a cantar, tive que retirar um aluno da sala. É só assim que se consegue dar aula!

Acho que o que falta nessa escola é vontade de trabalhar; disciplina exige uma constância - não é só falar, isso não funciona, não adianta falar com os pais, etc...etc. Na reunião de pais, uma das mães reclamou de um professor que falou "cala boca" aos alunos.

Entrei na sala para trabalhar uma canção, uma vez que o nosso projeto envolvia música de rock. Só que demorei 15 minutos para tentar dar aula. Jader não parava de falar. Liz circulava pela sala. Steph (a que roubou minha caixa de Bis e mexeu na bolsa da professora) circulava também pela sala - a mãe dessa menina havia sido convocada e até agora não havia aparecido. Liz saiu da sala, falando que estavam colocando cola Superbonder na carteira dele e, logo depois, a Stephanie saiu da sala, não me dando satisfação. Marcio (o que é analfabeto) também não estava no lugar; Mateus e Mauricio se atracando....

Mateus falou que todos os professores são chatos. Perguntei o que eles queriam. Não souberam responder. Um não ouve o outro. A gente tenta trabalhar com algo diferente, mas não dá. Tem que ser o método tradicional, copiar e copiar. Afinal, eles são copistas. Eles acham que só copiando é que aprendem. Fazer o quê, né?

$6^{\mathrm{a}} \mathrm{C}$ - Última aula. Pelo menos, nesta sala perdi só 10 minutos para colocar a sala em ordem, mas tive que ameaçar de chamar a irmã do Augusto, para ele sentar e parar de bagunçar (Professora Melissa/diário).

Para Groppa (op.cit., p.15) o "aluno-problema", em geral, é representado pelos professores como aquele que sofre de "distúrbios psicopedagógicos" - distúrbios "que podem ser de natureza cognitiva, também denominados de "distúrbios de aprendizagem" - ou distúrbio comportamental, nesse caso, é o indisciplinado. No entanto, para o autor, essa concepção cai por terra quando pensamos o sucesso escolar: se ele vem a ser produto da ação pedagógica, como explicar que o insucesso se deva aos efeitos de problemas individuais e 
anteriores do aluno, diz o autor? Pergunta ainda "se não estamos em certa medida nos isentando da responsabilidade sobre nossa ação profissional”.

Groppa sugere que revertamos a ordem de coisas como "repensar nossos posicionamentos, rever algumas supostas verdades que, em vez de nos auxiliar, acabam sendo armadilhas que apenas justificam o fracasso escolar, mas não conseguem alterar os rumos e os efeitos de nosso trabalho cotidiano" (op.cit., p.15).

Como vimos, o "bode expiatório" para esse grande mal, a indisciplina, que é vista como causadora do fracasso em ensinar Inglês, reside na "leitura mal feita" do que venha a ser a própria ação pedagógica, estabelecida e fundamentada em conceitos e crenças erroneamente formulados a respeito das relações entre os envolvidos no processo, professores e alunos...

Devemos, sim, considerar que hoje o professor não exerce o papel de superior, de "encarregado em distribuir e fazer cumprir ordens disciplinares, mas um profissional cujas tarefas nem sequer se aproximam dessa função disciplinadora, apassivadora, silenciadora, de antes" (op.cit., p.15).

O mesmo é válido para os alunos de hoje. Não são obedientes, quietos. Frente a um quadro diferente do passado, podemos entender a indisciplina como um protesto à intervenção do professor, do modo como ela acontece. Precisamos pensar o que se ensina, como se ensina e para que se ensina, para entendermos a indisciplina. Só assim entenderemos melhor por que o aluno quer chamar a atenção (op.cit., p.13).

Gostaríamos de salientar nessa indagação o lugar que o conhecimento ocupa e ressaltar seu lugar privilegiado na escola. A escola é o lugar do conhecimento e, portanto, o professor de Inglês deve primeiramente ter conhecimento da Língua Inglesa e de como ministrá-la. Caso esse contrato não se estabeleça, os alunos protestam.

Groppa (2010), em sua discussão sobre violência nas escolas (em programa de notícias da UOL internet, falando ao jornalista Marcelo Tamada ${ }^{2}$ ) adverte: “A indisciplina, em geral, é um protesto".

Em resumo, diante das lamentações presentes nos relatos dos sujeitos-professores, podemos perceber a visão que constroem de si mesmos e de seu trabalho. Sentem-se: (a) vítimas do processo; (b) não responsáveis por seus atos; (c) sozinhos, isolados, lutando para que ocorram mudanças. Assim se constrói a representação de um professor, aturdido por uma luta sem vencedores. A atitude que emerge para combater as dificuldades é a de um professor que deve exercer sua autoridade a qualquer preço, para poder dar aula, ora colocando o aluno para fora, ora mandando-o para a Diretoria, conforme observamos nos relatos a seguir:

\footnotetext{
${ }^{2}$ Disponível em: www.crmariocovas.sp.gov.br . Acesso em: 4 jan 2010.
} 
Você tem que ser meio general para funcionar, eu aprendi assim, são 30, 35 (na sala), eu acho que adolescente gosta de autoridade.

$\mathrm{O} R$, que cantava, tem problema de aprendizagem, ele não sabe ler, escrever, não está assim alfabetizado; achei ele indisciplinado, não é de agora, isso já vem de anos... (Professora Melissa/diário).

[...] com os alunos do Ensino Médio e as $8^{\mathrm{a}} \mathrm{s}$ é bom, mas com as $5^{\mathrm{a}} \mathrm{s}$ séries eu tenho de que ser durona (Professora Mariana/diário).

Para muitos desses profissionais, resgatar sua autoridade, no que diz respeito ao exercício profissional, é trabalhar com atividades com alto grau de dificuldade para o aluno. Esta é a forma escolhida por alguns para "deixar clara" a sua condição de superioridade intelectual:

O aluno que chega ao Ensino Médio não tem nenhum vocabulário, é muito pequeno, reduzido e, quando você começa a trabalhar com alguns textos um pouco mais avançados ou com conotação científica - coisas do cotidiano, ou coisas assim com que o mundo está preocupado, como preservação da natureza, sustentabilidade, aquecimento global - apesar de ocorrerem muitos cognatos, existem muitas palavras técnicas que eles desconhecem (Professor Gary/diário).

[...] propus um questionário que deveria ser começado em sala de aula e terminado em casa. Lição de casa: estudar o questionário para a prova (Professor Cybill/diário).

Uma vez que os "problemas" para a efetivação do ensino não estão no professor e também não são criados por ele, falar desses problemas significa pontuar as "agruras do ofício" indicando problemas que estão com o professor, um fardo que carrega e que “descarrega" nos alunos, na escola e em si mesmo.

\subsubsection{E a história continua e, de repente....}

Em um segundo momento, denominado por nós a luz no final do túnel, percebemos um gesto de esforço do professor: um momento em que seu corpo dá sinais de esforço e ele se queixa da fraqueza de sua voz, que se esvai por conta do grito lançado para conseguir a atenção da classe:

Essa semana foi relativamente calma, mas a voz quase se foi, de tanto que tivemos que gritar e falar alto em sala (Professora Melissa/diário).

A partir desse esforço do professor, começamos a vislumbrar as primeiras vozes de um ser que agora resolve tentar novamente. Um momento de "experimentação" no qual os 
professores começam a apresentar nos diários reproduções dos exemplos trabalhados no curso, aproximando-se do modelo Craft e, buscando aplicar técnicas presentes nos textos lidos e nas aulas do curso. Aos poucos, "percebem" os efeitos do planejamento das aulas e a interferência de atividades novas na participação/aprendizagem dos alunos, como se pode observar nos depoimentos:

Um momento bom essa semana? A troca de bilhetes em inglês, Valentines Day, e quando trabalhei uma song (Professora Melissa/diário).

Iniciei a aula pedindo que fizessem a leitura silenciosa do texto 'The 8th millenium goals' e grifassem as palavras que dificultavam a compreensão. Pedi também que observassem bem a figura que ilustrava cada um dos oito tópicos (Professora Ceci/diário).

Esses dois exemplos demonstram como as aulas do curso e os textos lidos interferiram no trabalho do professor. O primeiro exemplo recupera sugestões dadas no curso sobre o ensino da escrita de bilhetes: a leitura feita por outro aluno, a interação entre eles, a escolha do tema, o estímulo a práticas significativas, entre outros. Interessa também notar o uso de termos em Inglês pelo professor, resultado do que foi vivenciado no curso. O segundo exemplo é uma aplicação de sugestões trabalhadas no curso sobre leitura: a leitura de imagens como recurso, trabalho com vocabulário desconhecido no texto e a escolha do texto levando em conta a capacidade e a realidade dos alunos.

Como já enfatizamos anteriormente, por volta do final do primeiro semestre e início do segundo, observamos mudanças nos diários, especialmente relacionadas ao planejamento das aulas e a busca por atividades interessantes, como música, leitura de temas atuais, projeção de DVD, propagandas. Além disso, começamos a notar nas descrições dos professores mudanças significativas nas práticas utilizadas em sala e na interação com os alunos, resultantes do que estavam vivenciando no curso de formação:

Houve um dia em que não tivemos água na escola. Aproveitei a oportunidade, em meio a reclamações dos alunos, e comecei a conversar sobre higiene. Já fazendo o predicting, me lembrei do texto 'hygiene in space' e perguntei o que eles sabiam sobre astronautas, planetas, como eles imaginavam a rotina diária deles e de um astronauta, comparando alimentação, hábitos na Terra e no espaço. Ficaram super curiosos e completei falando sobre as experiências do astronauta brasileiro, quando esteve no programa do Jô Soares (Professora Iara/diário).

Inicia-se, portanto, um deslocamento: a voz do professor, até então voltada a seus obstáculos e vicissitudes, passa a ter como foco o aluno, que reage positivamente às novas atividades, aos novos assuntos. Coincidentemente, temos também a busca do professor pelo suporte, o respaldo dos pais, da escola e de outros professores. 
À guisa de exemplo dessa mudança de atitude - que denota mentalidade aberta para dividir responsabilidades - no quadro a seguir, observamos a descrição, no texto da professora Melissa (P1), de uma série de ocorrências sobre problemas com alunos indisciplinados que ilustram o processo de mudança de atitude da professora: do comportamento autoritário ao pedido de apoio aos pais e à cooperação dos alunos. Mudanças na prática escolar, com a oferta de atividades que os alunos apreciam e participam também são indicadoras desse processo de mudança da professora e que tem como resultado uma "melhora da disciplina da classe".

A forma pontiaguda nos ângulos retos representa a "ação" da professora Melissa, enquanto as formas arredondadas representam as "reações" da professora ou dos alunos à execução da ação. 

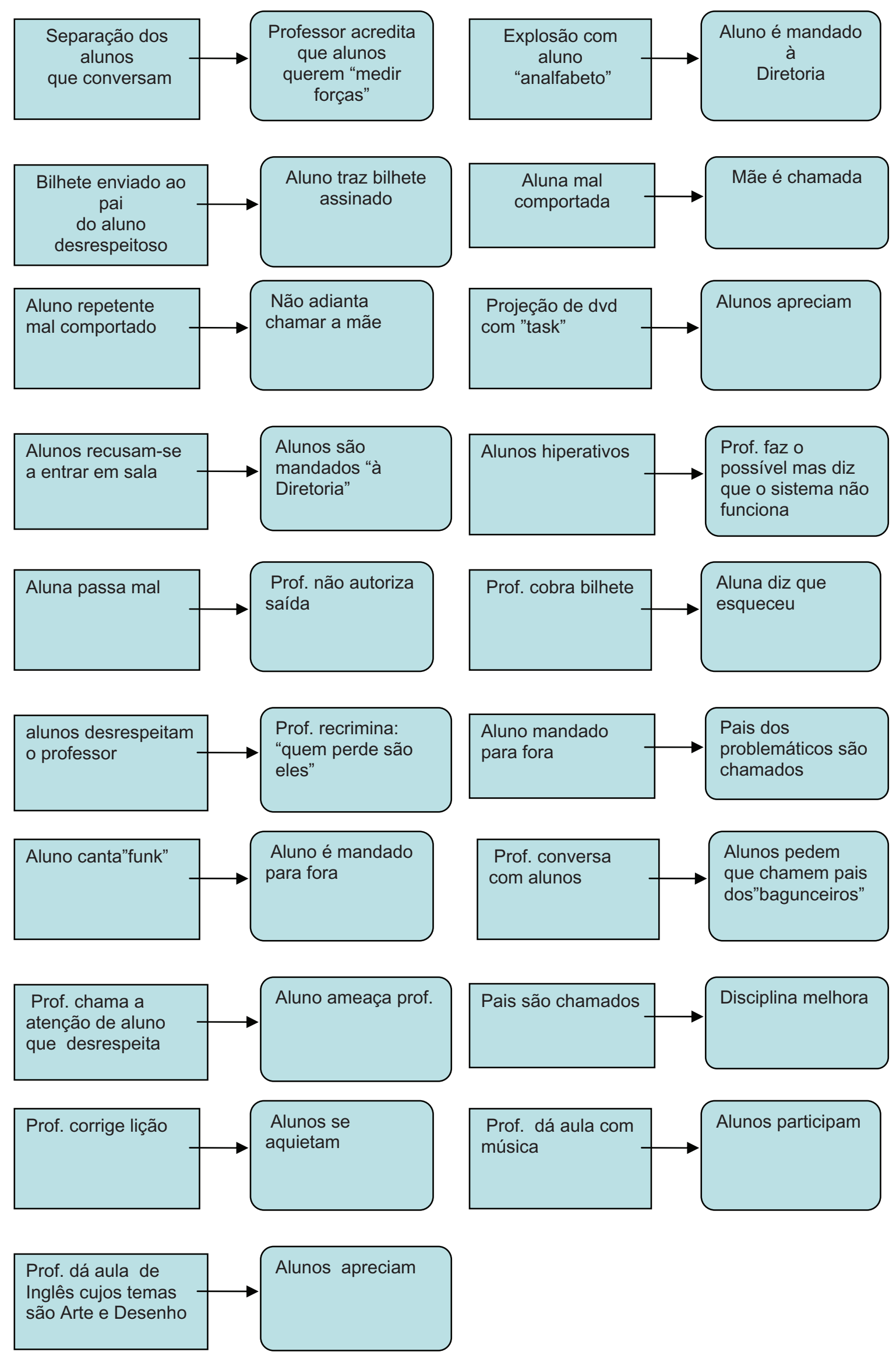

Quadro 2: Ações/reações da Professora Melissa. 
A presença dos pais tem um significado muito marcante nesses dados, do mesmo modo que a atitude dos alunos que evocam a presença dos pais para auxiliar a professora na resolução do problema da disciplina na classe. É bastante significativo e denota uma mudança de atitude de todos, professora e alunos o momento em que os próprios alunos pedem à professora para que chame os pais dos bagunceiros e que a professora, mesmo não acreditando mais nessa possibilidade, concorda e faz um acordo com a classe, instituindo regras de convivência claras. Após esse fato, a professora relata ter atingido maior controle na condução da aula. A voz dos alunos passa a ser ouvida, as aulas tornam-se mais interessantes e há consequente efeito sobre eles. É o prenúncio do terceiro momento, em que o professor pensa sobre o que fez em sala e no que resultou dessa reflexão. Começam a surgir nos relatos indícios da reflexão: ação e controle. As práticas escolares passam a levar em consideração os alunos e suas indagações a respeito da língua. E os professores começam a arriscar um pouco mais, conscientes do porquê dessa mudança:

Resolvi fazer esse trabalho [o corpo humano e suas partes, com colagem de revistas] com eles, devido a uma pergunta de uma aluna: perguntou por que "leg" era uma calça... (Professora Lydia/diário).

Como era uma atividade que eu nunca havia dado, os alunos gostaram muito! Todos tentavam prestar atenção na canção e levantar seu flash card... Todos gostam de um bom 'causo' de terror ou de contar o inexplicável! Tive a atenção total de todos os alunos nessa hora.

É mais fácil escrever o parágrafo, pois assim a classe vai se acalmando e vai ficando quieta porque tem que copiar algo da lousa.

Depois expliquei resumidamente a origem do Halloween, seus símbolos, etc. (Professora Melissa).

Nestes excertos podemos observar a professora responsabilizando-se pelas atividades e usando técnicas criadas no escopo da reflexividade, ela sabe como a classe se acalma e o assunto que os adolescentes apreciam (“terror”). A partir daí, elabora estratégias para resolver os problemas que surgem e divide responsabilidades com outros professores, como no próximo excerto:

Os alunos gostaram dessa atividade. Atenção total! Muitas dúvidas em relação à orientação sexual (gays, lésbicas) e preservativos de gravidez. $\mathrm{O}$ assunto que trouxe dúvidas foi passado para a professora de Ciências, para esclarecer (Professora Melissa).

Atitudes responsáveis, entusiasmo e modos de perceber a ação docente, buscando novos caminhos, são garantia para a prática pedagógica reflexiva, conforme vimos no primeiro Capítulo. Do mesmo modo, vimos com Nóvoa, também no Capítulo1, que a troca de experiências e o diálogo entre professores consolidam uma nova cultura. Nela, o exercício da autonomia e da identidade pessoal e profissional permite ao professor investir em si mesmo, 
fazendo valer os conhecimentos obtidos no curso para "experimentar" e consolidar outros saberes que lhe darão identidade própria.

Certamente os dados analisados são apenas indícios do que um curso de Formação Continuada pode oferecer aos professores. A sua organização e orientação parecem ter ajudado e interferido bastante no processo de reflexão dos participantes. Mesclar duas tendências, dando ênfase à estruturante no primeiro semestre, para informar os professores sobre teorias e práticas de sala de aula e, aos poucos, introduzindo uma linha mais interativa, de modo a incentivar o professor para mudanças e práticas autônomas, indica um possível caminho a seguir e a ser testado em outros cursos. 


\title{
CONSIDERAÇÕES FINAIS
}

\author{
Todos gostam de um bom "causo" de terror ou contar o \\ inexplicável! Tive a atenção total de todos os alunos nessa hora
}

Professora Melissa

Os resultados obtidos após a realização do curso de Formação Continuada para professores de Inglês da rede pública estadual e municipal de São Paulo (SP), aqui focalizado, clarificam a importância de se adotarem novos pressupostos a respeito de uma epistemologia da prática docente. No dizer de Santoro Franco (2005, p.439),

no processo de construção de conhecimentos sobre a prática docente, instala-se a crescente compreensão da inadequação entre os fundamentos da metodologia de base cartesiana e os pressupostos de uma epistemologia crítica da prática docente.

Evidenciamos, em nossa pesquisa, que as soluções pedagógicas alinham-se mais à formação do professor, se esta estiver aliada a teorias pedagógicas, a uma abordagem por competências que incite a considerar

os saberes como recursos a serem mobilizados, a trabalhar regularmente por problemas, a criar ou utilizar outros meios de ensino, a desenvolver projetos com os alunos, [...] a improvisar [...] a praticar uma avaliação formadora [...] a caminhar no sentido de uma menor compartimentalização disciplinar (PERRENOUD,1997 apud PERRENOUD, 2008, p.150).

Tem, também, importância, uma prática reflexiva que inclua flexibilidade para adaptar o ensino a classes diferentes. Entre a ação e a reflexão, encontra-se o professor como mediador, construindo ativamente seu desenvolvimento profissional, em conjunção com pesquisa, teoria, prática. Um ponto, no entanto, salienta-se. Mudanças de concepções são cruciais para que se consiga trabalhar com os alunos na sala de aula de Língua Inglesa. Refletir sobre essas novas concepções e práticas exige esforço e uma ruptura com crenças já arraigadas e muito salientadas em nosso corpus.

Assim, tendo como base os registros colhidos escritos nos diários, em entrevistas gravadas em áudio e em observação ao longo do ano de 2008, observamos que o curso, enquanto ocorreu, trouxe mudanças no que diz respeito ao ensinar a Língua Inglesa para o ensino fundamental e médio da rede pública. Primeiramente, podemos atribuir tal mudança ao aspecto teórico, como desenvolvido no curso, que propiciou aos professores a descoberta do que significa ensinar uma LE. 
No contexto desse curso de Capacitação, em que os professores da rede pública também participam de cursos de Capacitação Linguística, enfatiza-se o contexto significativo da língua inglesa, mais do que o acúmulo de informação a respeito de regras gramaticais. $\mathrm{O}$ ensino da tradução e da memorização de regras de gramática fica, nesse contexto, desprovido de uma função ou significação: seu lugar poderá ser resgatado posteriormente, quando já haja bom conhecimento da língua, e aí cumprirá um objetivo específico, mas, nos anos iniciais de aprendizagem da Língua Inglesa, o que deve ser salientado é, sem sombra de dúvida, o aspecto comunicativo do aprendizado da Língua Estrangeira, em vez de repetições mecânicas ou memorizações sem sentido ou mesmo traduções de palavras em listas e cruzadinhas fora de um contexto. A experiência no curso de Capacitação Linguística e o uso constante da língua inglesa no curso de Capacitação Metodológica trouxeram novos conhecimentos e novos modos de desenvolver suas habilidades, especialmente linguísticas.

Conhecimentos sobre teorias de ensino e suas aplicações auxiliaram os professores a instituir novas práticas, especialmente no preparo das aulas. Reproduções do que viram no curso foram utilizadas. No entanto, aos poucos essas reproduções foram ganhando identidade, incentivados pela orientação dada no curso, que estimulava a reflexão dos participantes.

Pudemos notar que a indisciplina dos alunos em sala tende a se tornar mais controlável em situações de aprendizagem em que todos estejam envolvidos em uma tarefa. Na visão de (AQUINO GROPPA,1998, p.12) ela "se desponta ou se acentua dependendo das circunstâncias. Por isso, talvez devemos indagar mais sobre essas circunstâncias, e por extensão, despersonalizar o nosso enfretamento dos dilemas disciplinares".

Referendamos o autor, com os dados aqui obtidos e analisados, na indicação de algumas premissas que abarcam o plano dos conteúdos e métodos que podem ajudar no enfrentamento dos sérios problemas disciplinares. Os quatro elementos básicos postulados pelo autor para uma pedagogia bem sucedida puderam ser observados na trajetória de mudanças: o primeiro diz respeito ao conhecimento - o professor deve ater-se ao seu âmbito pedagógico; o segundo refere-se à relação professor-aluno - relação que deve ser preservada em seus papéis e estimulada pela aprendizagem colaborativa; o terceiro elemento é a sala de aula, lugar em que equacionam os obstáculos e, finalmente, o quarto elemento vem a ser o contrato pedagógico. Esse contrato orienta o funcionamento da sala de aula, através de um código de regras comuns.

Para que cheguemos a essa pedagogia eficiente, é preciso rever uma série de conceitos sobre a prática escolar, como observamos nos resultados deste estudo. Um deles 
diz respeito a "dar voz ao aluno" para que ele possa sentir-se participante do processo. A observação do curso de Capacitação mostrou o deslocamento da fala do professor-aluno: de um comportamento silencioso para uma fala comprometida e responsável. Nessa trajetória do silêncio para essa fala comprometida surge outra, intermediária, em que o sujeito se dispõe a falar sobre suas próprias aulas, sobre o que ele faz. Nesse percurso, pudemos notar que o professor tem o que falar, ao interagir com o professor do curso e com os colegas. Esses momentos mostravam o sentido de pertencer a uma escola e a uma comunidade ou grupo de profissionais: "A minha 7"a"; "a minha classe"; "Nós, professores".

O curso de Formação Continuada teve papel importante na orientação teórica e metodológica e pareceu também contemplar algumas mudanças de atitude dos professores, como garantia de um relacionamento melhor entre eles e seus alunos. Os indícios de mudanças, marcados nos registros em diários e na apresentação de aulas, mostraram que, sem dúvida, é possível alterar e substituir práticas pedagógicas e que cursos de Formação Continuada podem servir de incentivo e de fio condutor para que elas ocorram. O conhecimento teórico e a utilização de modelos diferentes de formação em que tanto a reprodução como a aplicação de modelos tenha espaço, sempre mediadas pelo incentivo de uma prática reflexiva, podem trazer aos cursos de formação algum resultado efetivo.

Reiteramos, portanto, a importância da Formação Continuada, porém com a certeza de que a busca pelo conhecimento e aprimoramento do professor não tem fim. Acredita Gadotti (2008, p.41) que:

a formação continuada do professor deve ser concebida como reflexão, pesquisa, ação, descoberta, organização, fundamentação, revisão e construção teórica e não como mera aprendizagem de novas técnicas, atualização em novas receitas pedagógicas ou aprendizagem das últimas inovações tecnológicas.

Lembramos novamente que a formação contínua ou continuada do professor está apoiada em uma determinação legal. Esperamos, portanto, "que se cumpra a lei" que institui a obrigatoriedade desses cursos, como presente nas palavras de Santoro Franco (2005, p.439):

A legislação que subsidia políticas públicas de formação de professores no Brasil já considera que pesquisadores e docentes têm muito a ganhar, quando caminham e refletem juntos, articulando saberes mútuos que dão novo significado às pesquisas e qualificam o trabalho e a formação dos docentes. Esse caminho partilhado pode perspectivar a produção de uma nova ética, que estruture de forma mais coletiva as relações entre teoria e prática, respeitando e recriando uma nova cultura democrática, no processo de pesquisa e de formação docente. 


\section{REFERÊNCIAS BIBLIOGRÁFICAS}

ALLWRIGHT, D. Turns topics and tasks: patterns of participation in language learning and teaching. In: LARSEN-FREEMAN, D. (Ed.). Discourse Analysis in second language research. Rowley, Mass.: Newbury House, 1980, p.165-187.

ALLWRIGHT, D.; BAILEY, K.M. Focus on language classroom. London: LONGMAN, 1991.

ALONSO, M. O papel do diretor na administração escolar. In: HYPOLLITO, D. Formação continuada: análise de termos. (Artigo extraído da dissertação de mestrado: "Formação Continuada: dos desafios às possibilidades no cotidiano escolar”. PUC-SP, 1996).

APPLE, J. Diary of a language teacher. Great Britain: Heineman, 1995.

AQUINO, G. J. A indisciplina e a escola atual. Revista da Faculdade de Educação. São Paulo, vol. 24, n. 2, julho-dez. 1998. ISSN 0102-2555. Disponível em: <www.scielo.br $>$ Acesso em: 4 jan. 2010.

AQUINO, G. J. Do Cotidiano Escolar: Ensaios sobre a ética e seus avessos. 2. ed. São Paulo: Summus Editorial, 2000.

Entrevista concedida a Marcelo Tamada. Disponível em:

<www.crmariocovas.sp.gov.br>. Acesso em: 4 jan. 2010.

BROWN, H. D. Teaching by Principles. An Interactive Approach to Language Pedagogy. 2. ed. NewYork, USA: Longman, 2001.

CELANI, A. Língua Estrangeira. Não há uma receita no ensino de Língua Estrangeira. Entrevista concedida a Daniela Almeida. Disponível em: $<\mathrm{htpp}$ ://novaescola.abril.com.br $>$. Acesso em: 23 jun. 2009.

COLlARES C. A. L; MOYSÉS M. A. A. Construindo o sucesso na escola. Uma experiência de formação continuada com professorses da rede pública. In: Cadernos Cedes, 36. Educação Continuada. Campinas, SP: 1995, p. 95-110.

DEMO, P. Conhecimento moderno. Petrópolis, RJ: Vozes, 1997.

DEWEY, J. Democracia e Educação. Tradução: Godofredo Rangel e Anísio Teixeira. 3. ed. São Paulo: Companhia Editora Nacional, 1959.

FERREIRA, A. B. H. Novo Dicionário da Língua Portuguesa. Rio de Janeiro: Nova Fronteira. 
GARCIA, C. M. A formação de professores: Centro de atenção e pedra de toque. In: MARIN, Alda Junqueira (Org.) Educação Continuada. Campinas, SP: Papirus, 2004.

HERNÁNDEZ, F. A importância de saber como os docentes aprendem. In: MARIN, A. J. (Org). Educação Continuada. Campinas, SP: Papirus, 2004.

FERRO, G. d'O. M. A Formação do Professor de Inglês. Trajetória da Prática de Ensino de Inglês na Universidade de São Paulo. 1998. Tese de doutoramento. Faculdade de Educação da Universidade de São Paulo-USP, São Paulo, 1998.

Concepção da Disciplina: Línguas Estrangeiras Modernas. In: Diretrizes Pedagógicas. São Paulo: Sistema Ed. Franscicano, 2006, p.61-71.

FIELD, K. Teacher development: A study of the stages in the development of teachers. In: NÓVOA, A. Vida de Professores. 2. ed. Portugal: Porto, 2000.

FULLER, F. Concerns of teachers: A developmental perspective. In: NÓVOA, Antonio. Vida de Professores. 2. ed. Portugal: Porto, 2000.

FUSARI, J. C. A Educação de Educador em Serviço. 1988. Dissertação de mestrado. Faculdade de Educação. PUC, São Paulo, 1988.

GADOTTI, M. Boniteza de Um Sonho. Ensinar e aprender com sentido. Educação cidadã. São Paulo: Ed. L. Instituto Paulo Freire, 2008.

GINSBURG, M. The political dimension in teacher education: comparative perspectives. In: NOVOA, Antonio. Os professores e a sua formação. Temas de Educação. Lisboa: Dom Quixote Instituto de Inovação Educacional, 1995.

GOODSON, I. F. Dar voz ao Professor: As Histórias de Vida dos Professores e o seu Desenvolvimento Profissional. In: NÓVOA, A. (Org.). Vida de Professores. Portugal: Porto, 2000, p.63-69.

HELLER, A. Sociologia de la Vida Cotidiana. In: Educação e Pesquisa. Revista da Faculdade de Educação da USP. set; dez 2006. Education and Research. vol. 32. ISSN: 1517-9702. FEUSP.

O cotidiano e a história. In: Educação e Pesquisa. Revista da Faculdade de Educação da USP. set; dez 2006. Education and Research. vol. 32. ISSN: 1517-9702. FEUSP.

HYPOLlito, D. Formação Continuada: Análise de termos. In: HYPOLliTO, D. Formação Continuada: dos desafios às possibilidades no cotidiano escolar. 1996. Dissertação de mestrado. PUC, São Paulo, 1996.

HOLLY, M. L. Keeping personal-professional journal. Deakin: Deakin University Press, 1984. 
HUBERMAN, M. O ciclo de Vida profissional dos Professores. In: NÓVOA, A. (Org.). Vida de Professores. 2. ed. Portugal: Porto, 2000.

KOLB, D. A. Experiential learning: Experience as the source of learning and development. In: UR, P. The language teacher on-line: Teacher Training and Teacher Development. Disponível em: <www.jalt-publications.o rg/tlt/files/97/oct/ur.html>. Acesso em: 20 jan. 2009.

MACHADO, J. N. Educação competência e qualidade. Coleção Ensaios Transversais, 37. São Paulo: Escrituras, 2009

MARIN, A. J. Educação Continuada. Introdução a uma análise de termos e concepções. In: Cadernos Cedes, 36, Educação Continuada. Campinas, SP: Papirus, 1995.

MC DONOUGH, J.; MC DONOUGH, S. Research Methods for English Language Teachers. Londres: Arnold, 1997.

MELLO, G. N. Formação Inicial de Professores para a Educação Básica: Uma (Re)visão Radical. Cadernos POSGRAD. Universidade Católica de Santos, 2000.

MINISTÉRIO DA EDUCAÇÃO. Conselho Nacional de Educação. Diretrizes Curriculares para $o$ curso de Letras. Processo número: 23001.000126; 2001-69. Disponível em: $<$ htpp://inforum.insite.com.br>. Acesso em: 23 jun. 2009.

MINISTÉRIO DA EDUCAÇÃO. Lei de Diretrizes e Bases. Disponível em:

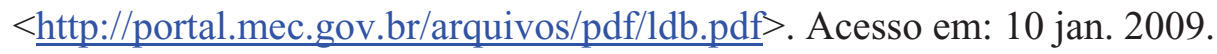

MONTEIRO, D. C.; GIOVANI, L. M. Formação Continuada de Professores: O Desafio Metodológico. In: MARIN, A. J. (Org). Educação Continuada. Campinas, SP: Papirus, 2004.

MORIN, E. Os sete saberes necessários a educação do futuro. Disponível em: $<$ htpp://ww2.prefeitura.sp.gov.br/secretarias/meioambiente/umapaz/files/Morin.pdf $>$. Acesso em: 12 maio 2009.

NÓVOA, A. Os professores e as histórias da sua vida. In: NÓVOA, A. (Org.). Vida de professores. Porto: Porto Editora, 2000.

. Formação de professores e profissão docente. In: NÓVOA, A. (Coord.) Os professores e a sua formação. Temas de Educação. Lisboa: Dom Quixote Instituto de Inovação Educacional, 1995.

- $O$ professor pesquisador e reflexivo. Disponível em: $<$ htpp://tvebrasil.com.br.saltoentrevistaantonio_novoa.htm>. Acesso em: 12 jul. 2009.

NUNAN, D. Research Methods in Language Learning. Cambridge Language Teaching Library. USA: CUP, 1992. 
PATTO, M. H. S. A produção do fracasso escolar: histórias de submissão e rebeldia. In: Educação e Pesquisa. Revista da Faculdade de Educação da USP. set; dez. 2006. Vol. 32. ISSN: 1517-9702. FEUSP.

PERRENOUD, P. A Prática Reflexiva no Ofício do Professor. Profissionalização e Razão Pedagógica. São Paulo: Artmed, 2002.

. Novas Competências para Ensinar. São Paulo: Artmed, 2000.

. Escola e Cidadania. São Paulo: Artmed, 2008, p.114.

PORTO, Y. S. Formação Continuada: A Prática Pedagógica Recorrente. In: MARIN, A. J. (Org). Educação Continuada. Campinas, SP: Papirus, 2004.

RAMOS, N. M. Educação Sustentável. 2. ed. São Paulo: ALTANA, 2006.

RODRIGUES, L. A. D. Formação Continuada em Língua Inglesa. In: PESSOA DE CARVAlHO, A. M. Formação Continuada de Professores. São Paulo: Thomson.

(2005). Dos fios, das tramas e dos nós: a tessitura da rede de crenças, pressupostos e conhecimentos de professores de inglês que atuam no ciclo I de Ensino Fundamental. 2005. Tese de doutoramento - Faculdade de Educação da Universidade de São Paulo, São Paulo, 2005.

SANTORO FRANCO, M. A. Em Foco: Pesquisa-ação sobre a prática docente. Apresentação. In: Educação e Pesquisa Revista da faculdade de educação da USP. set; dez 2005. Vol. 31. número 03.

SCHON, D. A. Educando o Profissional Reflexivo. São Paulo: Artmed, 2000.

SOUSA, D. T. R. Teacher continued education and school failure: problematizing the argument of incompetence. In: Educação e Pesquisa. Revista da Faculdade de Educação da USP. set; dez. 2006. Vol. 32. ISSN: 1517-9702. FEUSP.

UR, P. A Course in Language Teaching. Practice and Theory. Cambridge Teacher Training and Development. Great Britain: Cambridge University Press, 1996.

The language teacher on-line: Teacher Training and Teacher Development. Disponível em: <www.jalt-publications.org/tlt/files/97/oct/ur.html>. Acesso em: 20 jan. 2009.

VAN LIER, The Classroom and the language learner. Etnography and second Language classroom research. USA: Longman, 1988. 


\section{SITES VISITADOS}

<www.apliesp.org.br>. Acesso em: 11 jan. 2010.

INTERVOX NCE/UFRJ. Sobre Sartre. Disponível em:

$<$ http://intervox.nce.ufrj.br/ ballin/sartre2.doc $>$. Acesso em: 18 jun. 2008. 


\section{ANEXO 1 - EXCERTOS DOS DIÁRIOS ESCRITOS}

\section{PROFESSOR 1 - MELISSA}

\section{3 de abril}

Tive problemas com duas classes, nesta semana: um com a $7^{\mathrm{a}} \mathrm{C}$, porque algumas meninas queriam ficar juntas, em grupo, para fofocar no final de semana. Pedi que cada uma ficasse no seu lugar. Para quê? Começaram a me provocar, a medir forças e, enquanto eu colocava matéria na lousa, uma gritava para outra, do outro lado da sala: "E aí, você falou com ele?". Isso aconteceu às $7 \mathrm{~h}$, na primeira aula. Uma aluna, Laís, também continuou e continuou a provocar, assobiando, atrapalhando a aula. Tentei conversar com a sala, mas a tal da Laís quis medir forças; mandei a menina para a diretoria e a mãe foi chamada. Falei à classe que recebo a mesma coisa para dar uma ótima aula ou uma péssima aula. Quem estaria perdendo seriam eles.

A gente fala 1, 2, 3 vezes, na última a gente explode. Hoje em dia, para se dar aula, é necessário disciplinar a sala primeiro, colocar em ordem. E isso é que cansa o professor, que fica com síndrome de "burn out". Mas, refletindo depois sobre o ocorrido, creio que foi um pouco culpa minha também, porque não planejei direito a aula.

$\mathrm{O}$ outro problema foi com a $8^{\mathrm{a}} \mathrm{C}$. Eu falei diversas vezes para um aluno: "Rafael, presta atenção! Deixa a bolsa da Jéssica aí!” Mas ele ignorou e sequer abriu o caderno, pra começar a trabalhar. Mas o pior foi que, quando comecei a explicar, ele começou a cantar junto. Não tive dúvidas, mandei para fora, para falar com a auxiliar de período.

Graças a Deus, o resto da semana transcorreu sem maiores incidentes. A $7^{\mathrm{a}} \mathrm{C}$ falou que eu havia prometido música e não levei; falei que levaria na próxima semana!

\section{0 de abril}

Meu problema nesta semana foi nas 7 as E e B.

$\mathrm{Na} 7^{\mathrm{a}} \mathrm{B}$, levei uma canção - Dont stop the music -, para variar um pouco a aula. O R (aluno que não está alfabetizado e não quer frequentar aula de reforço) começou a dar problemas, a provocar um e outro, e não copiava nada da lousa. E eu falando para ele abrir o caderno e nada! Mudei-o de lugar (já era quase o final da aula), colocando-o sentado perto da lousa. Mesmo assim, quando coloquei a música pela segunda vez, para um exercício de filling the blanks, ele, para fazer gracinha, cantava "vai tomar no cu", no ritmo da música. Levei-o à diretoria e ele levou 2 dias de suspensão. Não era a primeira vez que aprontava e o pai já havia sido chamado várias vezes. Ele é de Codó, no Maranhão. A mãe o abandonou e ele diz que a odeia; uma única vez em que ele foi visitá-la, ela viajou para Brasília. O pior é que ele desestrutura toda sala!

Já, na $7^{\mathrm{a}} \mathrm{E}$, o $\mathrm{K}$ ficou nervosinho, porque falei para ele abrir o caderno e copiar a lição da lousa. Ele respondeu: "Vai enfiar o caderno no seu fiofó!". Escrevi um bilhete ao pai, vamos ver o que acontece...

$\mathrm{Na}$ semana passada, não tive problemas com a $7^{\mathrm{a}} \mathrm{C}$; depois que chamei a mãe da Laís, a turma das meninas sossegou. A cada semana uma surpresa! Com 16 anos de magistério, (só posso pensar que) ou você está sendo testada para ver até onde você vai, ou isso é um problema de 7 as séries. Tenho 12 classes ( 6as, 7as e 8as) e são as 7as que mais me dão problemas. Esta escola é considerada boa pela comunidade, mas tem muitos problemas disciplinares.

$\mathrm{O} \mathrm{R}$ da $8^{\mathrm{a}} \mathrm{A}$, jogou um apagador e quebrou a janela, mas, na verdade, ele queria ter acertado uma menina! Ele tem dado problemas desde a $1^{\mathrm{a}}$ série, mas a mãe não quer mudá-lo de escola 
e ele é repetente. Entra e sai da sala quando quer! Isso acontece na aula de Arte. E não adianta chamar a mãe, ela o protege e, também, já foi chamada trezentas vezes!

Tento trabalhar em pares, grupos, indivíduos e procuro fazer aulas bem diversificadas, mas está difícil. Já li alguns livros sobre disciplina, mas não há receita: uns falam que o professor não entra sozinho na sala, mas sim junto com o diretor, o coordenador, que é um trabalho coletivo; mas o sistema é que não funciona! Alunos analfabetos são os que são indisciplinados, têm problemas familiares etc etc. O ECA - Estatuto da Criança e do Adolescente - e o Conselho Tutelar são inúteis!

\section{8 de abril}

Esta semana até que fluiu bem, apesar de ter que enviar bilhetinhos para uns e outros pais de alunos. $\mathrm{O}$ Ka trouxe o bilhete assinado pelo pai, com número do telefone. $\mathrm{O} \mathrm{R}$ parece que se aquietou; fiz com ele um trato: se ele me deixar trabalhar até o final do ano, vai ganhar um presente. Vamos ver o que vai dar.

Os alunos, de forma geral, gostaram muito do DVD que levei - Interchange Intro. Para as 7as, como eu já havia trabalhado "roupas" e "comida", passei o DVD sobre isso. Foram 20 minutos e o "task" era para anotarem as palavras que entenderam, inclusive ganhariam ponto positivo pela tarefa. Foi muito estimulante para eles, pois puderam visualizar o vocabulário aprendido em sala de aula - a teoria na prática.

Com as 6as séries, o procedimento foi o mesmo, mas focando "profissões" e "partes da casa". Ficaram todos motivados.

\section{6 de maio}

Esta semana foi relativamente calma, apesar da segunda-feira: havia cerca de 10 alunos fora da sala de aula. A professora de História havia mandado 4 à diretoria; outros professores haviam mandado 1, nas suas respectivas aulas etc etc. Estamos chamado os responsáveis, para conter a indisciplina em sala. Os alunos que querem estudar não conseguem, por causa dos alunos desinteressados.

Ontem, a profa. Le, de Geografia, mandou 5 meninas da $7^{\mathrm{a}} \mathrm{C}$ à diretoria. Ontem também, 4 alunos da $6^{\mathrm{a}} \mathrm{D}$ ficaram fora da sala de aula e foram suspensos (dia de suspensão...). Era a $4^{\mathrm{a}}$ aula (minha aula) e a inspetora veio me perguntar se eu os colocara para fora ou eles é que haviam cabulado. $6^{\mathrm{a}} \mathrm{D}$. Na verdade, eles demoram para entrar em sala após o intervalo, então, após 10 minutos, não deixo ninguém mais entrar; fecho a porta e ninguém mais entra.

Fala-se em qualidade na Educação, mas é impossível dar aula, se o aluno não tem base. Outro dia, tive que substituir um professor na $5^{\mathrm{a}} \mathrm{B}$ (Ex-classe pic). Levei a música do Old McDonald e pus a letra na lousa, mas muitos não sabiam copiar, porque escrevi em letra cursiva; eles só sabiam ler em letra bastão. Eles até frequentam um programa de reforço (SAP), na parte da tarde, mas há ainda um longo caminho a percorrer. E não é só isso... estão sempre andando de um lado para o outro, são dispersos e hiperativos. Sei que os tempos são outros e que os alunos são diferentes, mas há conteúdos de todas as matérias que, por mais que se diversifiquem as aulas, têm que ser dados e, para isso, são necessárias concentração e atenção. A escola faz o possível e o professor também, mas o sistema não funciona.

\section{9 de maio}

Nesta semana tive problemas com a aluna $C$, da $7^{\text {a }} \mathrm{E}$ : ela disse que estava passando mal e queria sair; não deixei, pois é uma aluna que não faz as atividades, só conversa e passeia pela sala. A mãe veio reclamar de mim para a diretora, trazendo atestado médico de gastrite. Enviei um bilhete, dizendo que ela não parecia nada mal, porque ficara lendo uma revista durante a aula, e quando escrevi o bilhete é que ela deve ter ficado nervosa. Também conversei com outros professores que falaram que ela era displicente e coloquei no bilhete 
que todos estavam reclamando dela - professores de Matemática, Português, Geografia, História, e eu, de Inglês. Eles me contaram que ela mostrou o bilhete a eles e perguntou se concordavam.

A mãe, segundo o bilhete que enviou à diretora, falou que, da próxima vez, iria reclamar no Conselho de Educação. Eu tinha 2 saídas: ou ficava quieta e deixava pra lá, ou enfrentava a mãe, que não havia assinado o bilhete. Resolvi enfrentar, porque o que ela estava fazendo não era o correto. Vamos ver o que vai dar...

Então, nós professores refletimos: "Será que é necessário passar por tanto estresse?" Meu marido fala que, se eles não querem estudar, o problema é deles. Mas é fácil falar, quando se está de fora. Se o aluno enfrenta o professor e este não faz nada, a classe vira uma balbúrdia. Mas, ao mesmo tempo, eu penso: "Pra que tanto empenho, se os pais não dão valor, nem os alunos?" Procuro não faltar, não chegar atrasada, às vezes gasto dinheiro do meu bolso com xerox, mas não vejo retorno! É desanimador! Talvez minha colega tenha razão, ficamos de babá na sala e, às vezes, nem é possível dar aula; ela diz que quem quiser que tire dúvida com ela. Mas fala isso porque tem livro didático. Eu, de Inglês, como não tenho, preciso colocar a matéria na lousa ou xerocar o material.

Enviaram somente 9 livros paradidáticos para trabalhar, mas como trabalhá-los, com 35 alunos em aula? Foi dinheiro jogado no lixo, ou alguém saiu ganhando com isso, porque não tem lógica distribuir vários livrinhos, com apenas 9 exemplares de cada coletânea. Há, também, umas biografias em que o inglês é tão difícil para o nível deles, que nunca irei usar: Ghandi, Beatles, etc. Quem escolheu os livros, certamente nunca deu aula em rede pública e não conhece a dinâmica: eles não gostam dos Beatles, gostam de músicas atuais, tipo Akon, Pussycat dolls, U2, etc. That's the reason why teachers get burn out, and health problems!

\section{3 de junho}

Esta semana foi relativamente calma, mas minha voz quase se foi, de tanto que tivemos que gritar e falar alto em aula.

TENTO DIVERSIFICAR AS AULAS, MAS NEM SEMPRE É POSSIVEL.

A C (a do bilhete) faltou na quarta-feira. Thank God! Na segunda-feira, cobrei o bilhetinho assinado pela mãe e ela disse que havia esquecido.

Nessa mesma classe ( $\left.7^{\mathrm{a}} \mathrm{E}\right)$, fiquei esperando um tempo fora da sala porque, como a sala é do lado de fora do prédio principal, na troca do professor eles aproveitam para fechar a porta e deixar o professor para fora. Fiquei um tempo esperando abrirem e, como não abriram, pedi a uma aluna que também ficara fora para buscar a chave. Falei para eles que quem perde são eles; eu ganho do mesmo jeito. Já deixaram a mim e a professora de Ciências para fora, não sei se alguém mais.

Então, durante a aula, começam a cantar uma canção funk, falando sobre drogas. Falei que esse tipo de canção era "apologia ao crime" e, como toda vez que eu virava para a lousa, eles começavam a cantar, tive que retirar um aluno da sala. É só assim que se consegue dar aula! Muitos professores vão se transferir desta escola, mas eu não. Tenho lido vários artigos de "rapport" e "motivation", mas ainda não surtiram efeito. Parece-me que você só é ouvido quando exerce a autoridade. O aluno "apronta" e nada se pode fazer a respeito. Conselho Tutelar não funciona, nada funciona.

Um momento bom esta semana? A troca de bilhete em inglês, no Valentine's Day, e o trabalho com uma song.

\section{0 de junho}

Esta semana foi relativamente tranquila, exceto por quinta-feira. Notei que a maioria dos professores está desanimada, pelo pouco interesse dos alunos e desorganização da escola. $\mathrm{O}$ sinal na troca das aulas não toca mais regularmente, só uma vez ou outra, então eu sigo o meu 
relógio. Tudo é difícil nesta escola: na sexta-feira, pedi uma carta, para fazer um curso da XXXX, e só fui recebê-la na quarta-feira... e isso porque insisti muito, na segunda e terçafeira. Na secretaria há 4 professores readaptados, mas eles não fazem nada; há dois secretários, mas um vive faltando e o outro estava num curso. Acho que os professores readaptados deveriam trabalhar mais.

Conversei com a $7^{\mathrm{a}} \mathrm{E}$ e a $7^{\mathrm{a}} \mathrm{A}$, esta semana, e os próprios alunos pediram para chamar os pais dos bagunceiros. Falei com a coordenadora e com os professores, mas eles não demonstraram muito interesse na reunião com os pais. Insisti muito e, finalmente, a coordenadora concordou. Afinal, eu, a professora de História e a de Geografia já havíamos falado com a classe e nada havia adiantado.

Acho que o que falta nessa escola é vontade de trabalhar; disciplina exige uma constância não é só falar, isso não funciona, não adianta falar com os pais, etc... etc. Na reunião de pais, uma das mães reclamou de um professor que falou "cala boca" aos alunos. Eu não falei isso, mas mesmo assim retruquei que, apenas pedindo silêncio, a classe não se aquieta. Os alunos que estavam presentes na reunião concordaram. É fácil falar, quando não se está na sala de aula; ninguém imagina a bagunça que é.

\section{9 de agosto}

Esta semana foi relativamente boa, pois estamos chamando os pais dos alunos problemáticos e a disciplina em sala de aula melhorou, no geral.

Entrei na $6^{\circ}$ série, cumprimentei a todos: "Good afternoon". Coloquei o ponto na lousa, para depois explicar. Eu sei que o certo seria fazer um warm up, etc., mas a teoria na prática é a outra. Escrevo o ponto e os exercícios de fixação no quadro, para depois explicar.

Trabalhei as prepositions -in, on, at, etc. Há classes em que eu consigo trabalhar com os 3 pês (pre, while, post activity), em outras, não. Introduzo as preposições com o famoso the book is on the table, e prossigo com Where is the pen? (com mímicas): on the book, in the pocket, in front of, etc., posicionando a caneta de acordo com a fala. Os alunos respondem oralmente. Depois explico o esquema de preposição que está na lousa, eliciting ou traduzindo mesmo o significado de on, in, etc. Pergunto se tem alguma dúvida e, então, eles respondem os exercícios de answer in English e, depois, um exercício de version, pois acredito que assim eles têm mais segurança. Dou 5 minutos para fazerem e começo a corrigir. Quando eu vejo que estão conversando, já começo a corrigir. Quem vai fazer o primeiro exercício ganha ponto positivo. Os alunos sabem que o que está respondido na lousa já é o correto. Depois faço a correção geral.

Trabalho no máximo 2 aulas com o mesmo ponto. Depois passo para o próximo. Tive que dar preposição este ano e vou ter que dar as horas também, porque eles não tiveram isso na $5^{\circ}$ série. Eles tiveram professor, mas ele só trabalhava desenho e tradução com o dicionário.

\section{8 de setembro}

$7^{\mathrm{a}} \mathrm{A}$ - Entrei na sala para trabalhar uma canção, uma vez que o nosso projeto envolvia música de rock. Só que demorei 15 minutos para tentar dar aula. Jader não parava de falar. Liz circulava pela sala. S (a que roubou minha caixa de Bis e mexeu na bolsa da professora) circulava também pela sala - a mãe dessa menina havia sido convocada e até agora não havia aparecido. Le saiu da sala, falando que estavam colocando cola Superbonder na carteira dele e, logo depois, a S saiu da sala, não me dando satisfação. Mateus (o que é analfabeto) também não estava no lugar; Mateus e Marcos se atracando....

Escrevi a canção na lousa (You're always on my mind, do Elvis) mas, mesmo assim, a sala não se aquietou. E (o que também tem dificuldade de aprendizagem) colocava o pé no armário e nem abriu o caderno para copiar. Falei que, se ele não estava interessado em aprender, que saísse da sala. Tentei conversar com a classe, para ver se fazíamos um acordo, 
mas nada. Não consegui colocar a música e não deu em nada. $\mathrm{N}$ falou que eu não deveria dar música, pois gerava bagunça. Outra aluna falou que eu deveria ser mais enérgica. Mateus falou que todos os professores são chatos. Perguntei o que eles queriam. Não souberam responder. Um não ouve o outro. A gente tenta trabalhar com algo diferente, mas não dá. Tem que ser o método tradicional, copiar e copiar. Afinal, eles são copistas. Eles acham que só copiando é que aprendem. Fazer o quê, né?

$6^{\mathrm{a}} \mathrm{C}$ - Última aula. Pelo menos, nesta sala perdi só 10 minutos para colocar a sala em ordem, mas tive que ameaçar de chamar a irmã do Augusto, para ele sentar e parar de bagunçar. Dois grupos apresentaram o trabalho de música e fiz uma atividade de listening, com descrição do quarto de Van Gogh.

Continuação da atividade na próxima aula.

\section{4 de setembro}

Entrei na $6^{\mathrm{a}} \mathrm{C}$ e cumprimentei os alunos. Falei que iríamos trabalhar o listening task.

Comecei com o nursery rhyme Hickory Dickory Dock, eles copiaram da lousa e fizemos a performance do pêndulo do relógio, o rato subindo o pêndulo, etc. Como eles já haviam aprendido as horas, o nursery ficou como warm up. Em seguida, coloquei uma tabela para eles completarem, de acordo com o listening (CD Intro, de Jack Richards). Eles comentaram que gostaram da atividade, porque era do tipo filling the blanks. Corrigimos depois (sempre valendo ponto positivo!). Esta é uma classe que estou utilizando como classe-projeto para o portfólio do Alumni.

\section{9 de setembro}

Entrei na $6^{\mathrm{a}} \mathrm{C}$, dei um exercício de Question/Answer, de acordo com a tabela anterior (do dia 24 de set.). Correção do exercício. Para finalizar, tinham que fazer uma tabela do dia a dia deles e entregar numa folha à parte. A tabela consistia em horas e dias da semana.

Entrei na $7^{a} \mathrm{~A}$, "A" de "A classe problema". Tentei corrigir a lição de casa - que por sinal somente um aluno (João) havia feito -, na medida do possível, porque era uma conversa sem fim! Vira e mexe, tive que chamar a atenção do Daniel, Stephanie, Tiago, Kaíque, Edson, etc. Tentei fazer um warm up com o texto que eu havia xerocado, In Prison, que tinha a estrutura do futuro que eles haviam aprendido. Só que o meu clustering ficou muito pobre, porque não dava para ninguém ouvir ninguém (e olha que eu uso o amplificador de voz para dar aula!). Resolvi, então, já distribuir o Xerox para eles lerem. Eu lia, eles repetiam e eu ia explicando o vocabulário que eles não entendiam. Gostaria de ter dividido a classe em duas turmas, para eles praticarem a pronúncia ou lerem aos pares, mas com essa classe é impossível. Escrevi algumas perguntas de compreensão para responderem, porque eles são copistas, e só sossegam quando têm algo para copiar.

A coordenadora foi chamada porque o Daniel não parava de falar durante a explicação, mas não adiantou nada. Ela levou o aluno para conversar e trouxe de volta alguns minutos depois porque, segundo ela, não se pode colocar o aluno fora da sala de aula. Ela é uma coordenadora nova, nunca trabalhou na prefeitura, está mais do que perdida. Ela trabalhava em uma escola particular e não sabe o que fazer.

Todos os professores têm problema com essa sala. Os pais desses alunos foram chamados já mais de 3 vezes e nada se resolve. Os pais mesmos falam "Não sei mais o que fazer com ele!" Por causa do ECA, a qualidade da Educação decai mais e mais..., mas o sistema é que não funciona! A professora de História dita a matéria, porque é a única maneira de eles ficarem quietos! 


\section{6 de outubro}

\section{LESSON PLAN (Listening Skill)}

There is/are /prepositions: "The Bedroom" (Van Gogh)

\begin{tabular}{|c|c|}
\hline Parts of Lesson & Comments \\
\hline $\begin{array}{l}\text { Warm up: Checar com os alunos o conhecimento prévio que } \\
\text { eles têm sobre o artista Vincent Van Gogh. Esquematizar na } \\
\text { lousa, um breve resumo de sua vida, suas obras, etc. }\end{array}$ & $\begin{array}{lcc}\text { Alguns } & \text { alunos } & \text { já } \\
\text { ouviram falar do } \\
\text { pintor; outros, não. }\end{array}$ \\
\hline $\begin{array}{l}\text { Pre-reading: Relembrar partes do quarto em inglês: bed, } \\
\text { doors, windows, etc. } \\
\text { Vocabulário do quadro de Van Gogh "The Bedroom" }\end{array}$ & $\begin{array}{l}\text { O vocabulário foi } \\
\text { colocado na lousa. }\end{array}$ \\
\hline $\begin{array}{l}\text { While-reading: Esquematizar as } 3 \text { paredes do quarto, } \\
\text { posicionando a janela e as duas portas, na lousa, para facilitar } \\
\text { a compreensão do aluno. Os alunos têm que desenhar os } \\
\text { móveis, de acordo com a descrição da professora: "There are } \\
4 \text { pictures on the wall, next to the right door. There is a table } \\
\text { in front of the window...." } \\
\text { O quadro utilizado é "The Bedroom", de Van Gogh. } \\
\text { Os alunos rascunham os móveis numa folha separada que, } \\
\text { depois, é recolhido pela professora. Ela mostra o quadro } \\
\text { original e verifica quem acertou a exata posição dos móveis. }\end{array}$ & $\begin{array}{l}\text { Mesmo } \\
\text { esquematizando na } \\
\text { lousa as } 3 \text { paredes, dois } \\
\text { alunos não } \\
\text { conseguiram copiar o } \\
\text { desenho em 3D da } \\
\text { parede. A professora } \\
\text { acabou desenhando } \\
\text { para um desses alunos. } \\
\text { Alguns copiaram o } \\
\text { desenho do colega. }\end{array}$ \\
\hline $\begin{array}{l}\text { Post-reading: true/false exercises. } \\
\text { A professora afixa o quadro na lousa e solicita aos alunos que } \\
\text { observem o quadro e respondam se é "true or false". } \\
\text { Exemplo: } \\
\text { a) There are } 3 \text { pictures on the wall.( ) } \\
\text { b) There is a table next to the door. ( ) } \\
\text { c) There is a vase on the table.( ) }\end{array}$ & $\begin{array}{l}\text { A maioria dos alunos } \\
\text { não apresentou } \\
\text { dificuldades em fazer } \\
\text { esta atividade. }\end{array}$ \\
\hline $\begin{array}{l}\text { Wrap up: Homework: desenhar o seu quarto, utilizando as } \\
\text { preposições e "there is/are" }\end{array}$ & $\begin{array}{l}\text { Muitos desenharam o } \\
\text { quarto, mas } \\
\text { esqueceram de usar o } \\
\text { "there is/are" para } \\
\text { indicar a existência dos } \\
\text { móveis. }\end{array}$ \\
\hline $\begin{array}{l}\text { General Comments: A classe, em geral, gostou e conseguiu } \\
\text { realizar esta atividade, mas é importante ressaltar que a parte } \\
\text { gramatical there is/are e as prepositions foram trabalhadas em } \\
\text { aulas anteriores. }\end{array}$ & \\
\hline
\end{tabular}


LESSON PLAN (Listening Skill)

"Welcome to my Life" (song)

\begin{tabular}{|l|l|}
\hline Parts of Lesson & Comments \\
\hline $\begin{array}{l}\text { Warm up: Escrever o nome dos alunos. Os alunos devem } \\
\text { colocar um adjetivo, uma qualidade boa para cada aluno } \\
\text { (dependendo do nível da classe, pode ser em português ou em } \\
\text { inglês). }\end{array}$ & $\begin{array}{l}\text { Os alunos gostaram } \\
\text { muito desta atividade. } \\
\text { Afinal quem não gosta } \\
\text { de receber um elogio? }\end{array}$ \\
\hline $\begin{array}{l}\text { Pré-reading: clustering the title of the song Welcome to my } \\
\text { life }\end{array}$ & $\begin{array}{l}\text { Quem é bem-vindo e } \\
\text { quem não é? Será que } \\
\text { canção fala sobre os } \\
\text { excluídos? } \\
\text { Quem são os excluídos } \\
\text { da sociedade? }\end{array}$ \\
\hline $\begin{array}{l}\text { While-reading: A professora escreve a letra na lousa, com } \\
\text { algumas lacunas (verbos). }\end{array}$ & $\begin{array}{l}\text { A maioria achou a } \\
\text { canção "emo", não } \\
\text { Faz a leitura da letra, para esclarecer dúvidas quanto ao } \\
\text { vocabulário. Coloca o CD para os alunos ouvirem. }\end{array}$ \\
$\begin{array}{l}\text { Os alunos completam as lacunas e cantam, se quiserem, } \\
\text { praticando a pronúncia. }\end{array}$ & $\begin{array}{l}\text { As meninas foram as } \\
\text { que mais gostaram. }\end{array}$ \\
\hline $\begin{array}{l}\text { Post-reading: Discutir quem são os excluídos. Direcionar o } \\
\text { assunto para a sexualidade. Solicitar aos alunos que escrevam } \\
\text { num pedaço de papel as dúvidas a respeito. Discutir ou } \\
\text { pesquisar. Homework: fazer frases com os verbos das lacunas. }\end{array}$ & $\begin{array}{l}\text { Os alunos gostaram } \\
\text { desta atividade, } \\
\text { atenção total! Muitas } \\
\text { dúvidas em relação à } \\
\text { orientação rexual } \\
\text { gays, lésbicas) e } \\
\text { preservativos de } \\
\text { gravidez. O assunto } \\
\text { que trouxe dúvidas foi } \\
\text { passado para a } \\
\text { professora de Ciências, } \\
\text { para esclarecer. }\end{array}$ \\
\hline $\begin{array}{l}\text { Wrap up: Distribuir cartolina ou sulfite para os alunos } \\
\text { escreverem ou recortarem figuras de revistas Who is welcome } \\
\text { to your life? }\end{array}$ & $\begin{array}{l}\text { Como era de se esperar } \\
\text { as palavras foram: } \\
\text { talvez devesse ter escolhido outra canção. } \\
\text { etc. family, pets }\end{array}$ \\
\hline
\end{tabular}


LESSON PLAN (Listening Skill)

What time is it?

\begin{tabular}{|c|c|}
\hline Parts of Lesson & Comments \\
\hline $\begin{array}{l}\text { Warm up: Nursery rhyme Hickory Dickory Dock. } \\
\text { A professora escreve a rima na lousa, esclarece o vocabulário } \\
\text { e os alunos fazem a performance da rima. }\end{array}$ & $\begin{array}{l}\text { Os alunos gostam desta } \\
\text { atividade, pois há } \\
\text { movimento. }\end{array}$ \\
\hline $\begin{array}{l}\text { Pre-reading: A professora coloca o esquema na lousa (filling } \\
\text { the blanks) e os alunos devem completar algumas partes com } \\
\text { a informação que eles ouvirem no CD. Ela explica que é um } \\
\text { programa de rádio no qual o apresentador telefona para } \\
\text { pessoas de várias partes do mundo e pergunta as horas e o que } \\
\text { elas estão fazendo. }\end{array}$ & $\begin{array}{l}\text { Relembrar os países } \\
\text { (Austrália, Rússia etc.) } \\
\text { e os verbos (watch, } \\
\text { study,etc.) Apesar de } \\
\text { não ter sido feito, os } \\
\text { alunos conseguiram } \\
\text { realizar a atividade. }\end{array}$ \\
\hline $\begin{array}{l}\text { While-reading: A professora toca o CD } 2 \text { vezes e depois } \\
\text { confere a resposta. }\end{array}$ & $\begin{array}{l}\text { Gostaram } \text { desta } \\
\text { atividade, pois nunca } \\
\text { haviam trabalhado } \\
\text { dessa forma. }\end{array}$ \\
\hline $\begin{array}{l}\text { Post-reading: Exercícios de Question/Answer, no caderno. } \\
\text { Exemplo: What time does Lucy have lunch? } \\
\text { Who lives in Sidney?. Correção da atividade em classe. }\end{array}$ & $\begin{array}{l}\text { Os alunos não tiveram } \\
\text { dificuldades em } \\
\text { responder. Mas sempre } \\
\text { tem que valer ponto } \\
\text { positivo para aquele } \\
\text { que acertou a resposta! }\end{array}$ \\
\hline $\begin{array}{l}\text { Wrap up: Homework ou na sala de aula: elaborar your day by } \\
\text { day schedule. What time do you have lunch, study etc.? }\end{array}$ & $\begin{array}{l}\text { Aprenderam vários } \\
\text { verbos novos: surf on } \\
\text { the net, go roller } \\
\text { skating, etc. }\end{array}$ \\
\hline $\begin{array}{l}\text { General Comments: Antes de trabalhar esta atividade, as } \\
\text { horas e os verbos no simple present foram trabalhados, por } \\
\text { isso os alunos não tiveram maiores dificuldades na realização } \\
\text { desta atividade. }\end{array}$ & \\
\hline
\end{tabular}


LESSON PLAN (Listening Skill)

"Halloween"

\begin{tabular}{|c|c|}
\hline Parts of Lesson & Comments \\
\hline $\begin{array}{l}\text { Warm up: Escrever um parágrafo ou falar sobre } \\
\text { a origem do Halloween. }\end{array}$ & $\begin{array}{l}\text { É mais fácil escrever o parágrafo, pois } \\
\text { assim a classe vai se acalmando e vai } \\
\text { ficando quieta, porque tem que copiar } \\
\text { algo da lousa. } \\
\text { Depois expliquei resumidamente a } \\
\text { origem do Halloween, seus símbolos } \\
\text { etc. }\end{array}$ \\
\hline $\begin{array}{l}\text { Pré-Listening: Escrever a instrução e as palavras } \\
\text { na lousa, relacionadas ou não ao listening task, } \\
\text { no caso: ghost, step, cemetery etc. O objetivo é } \\
\text { marcar a palavra que apareceu no DVD. }\end{array}$ & $\begin{array}{l}\text { Como era um assunto novo, todos } \\
\text { participaram. }\end{array}$ \\
\hline $\begin{array}{l}\text { While-Listening: Colocar o DVD para ouvir. No } \\
\text { meu caso, fiz uma gravação de } 25 \text { minutos do } \\
\text { clip do Michael Jackson - Thriller, como dançar } \\
\text { o Thriller e a história do Halloween. (You Tube) }\end{array}$ & $\begin{array}{l}\text { Tive problemas com a parte do } \\
\text { Thriller, que parava um pouco; } \\
\text { preciso regravar o DVD. Os alunos } \\
\text { gostaram muito, só não consegui que } \\
\text { ouvissem a história do Halloween em } \\
\text { inglês (os alunos pediram para parar!) }\end{array}$ \\
\hline $\begin{array}{l}\text { Post-Listening: Corrigir o listening. Distribuir a } \\
\text { palavra cruzada do Halloween, em inglês. }\end{array}$ & $\begin{array}{l}\text { Devido à qualidade do som, poucos } \\
\text { conseguiram ouvir bem, mas a } \\
\text { maioria conseguiu realizar a atividade } \\
\text { proposta. }\end{array}$ \\
\hline $\begin{array}{l}\text { Wrap up: Concurso "O Melhor Conto de } \\
\text { Terror". Começar contando uma lenda urbana ou } \\
\text { algum caso horripilante que aconteceu com um } \\
\text { amigo de um amigo seu. Se os alunos não } \\
\text { quiserem contar (geralmente somente } 1 \text { ou } 2 \\
\text { gostam de falar na frente da classe), solicite a } \\
\text { eles para escreverem o conto numa folha de } \\
\text { papel, em português mesmo, depois recolha e } \\
\text { escolha o melhor. Valendo premiação! }\end{array}$ & $\begin{array}{l}\text { Todos gostam de um bom "causo" de } \\
\text { terror ou contar o inexplicável! Tive a } \\
\text { atenção total de todos os alunos nessa } \\
\text { hora. }\end{array}$ \\
\hline $\begin{array}{l}\text { General Comments: Todo aluno gosta quando a } \\
\text { aula envolve DVD, porque é uma aula diferente. } \\
\text { O story telling, mesmo sendo em português, é } \\
\text { algo que todos gostam de ouvir. Quem não gosta } \\
\text { de uma boa história? }\end{array}$ & \\
\hline
\end{tabular}


LESSON PLAN (Listening Skill)

Perhaps Love (song)

\begin{tabular}{|c|c|}
\hline Parts of Lesson & Comments \\
\hline Warm up: Fazer tempestade de idéias da palavra $L O V E$. & $\begin{array}{l}\text { Na verdade, mostrei os } \\
\text { flash cards e verifiquei } \\
\text { se eles sabiam o que } \\
\text { era : cloud, rain, etc. }\end{array}$ \\
\hline $\begin{array}{l}\text { Pre-Listening: Trabalhar as palavras do flash card (ocean, } \\
\text { cloud, etc) e questionar com o aluno por que o compositor } \\
\text { compara o amor à porta (door) ou à janela. } \\
\text { Colocar na lousa uma parte da canção e analisá-la, porque é } \\
\text { uma canção muito longa. }\end{array}$ & $\begin{array}{l}\text { Escrevi uma parte da } \\
\text { canção e pedi para que } \\
\text { os alunos copiassem. } \\
\text { Trabalhei os } \\
\text { vocabulários } \\
\text { desconhecidos. }\end{array}$ \\
\hline $\begin{array}{l}\text { While-Listening: Colocar o CD com a canção Perhaps Love } \\
\text { (Plácido Domingo e John Denver). Entregar aos alunos os } \\
\text { flashcards com as figuras que vão aparecer na canção: sea, } \\
\text { love etc. Cada vez que os alunos ouvirem a palavra do seu } \\
\text { card, eles levantam o card. }\end{array}$ & $\begin{array}{l}\text { Como era uma } \\
\text { atividade que eu nunca } \\
\text { havia dado, os alunos } \\
\text { gostaram muito! Todos } \\
\text { tentavam prestar } \\
\text { atenção na canção e } \\
\text { levantar seu flash card. }\end{array}$ \\
\hline $\begin{array}{l}\text { Post-Listening: Construir frases com as palavras do } \\
\text { flash card. Grammar task: retirar dois verbos, um adjetivo do } \\
\text { texto, explicar uma frase, etc. }\end{array}$ & $\begin{array}{l}\text { Tiveram alguma } \\
\text { dificuldade para } \\
\text { realizar a tarefa, pois } \\
\text { não sabiam a diferença } \\
\text { entre um substantivo e } \\
\text { um adjetivo, mas } \\
\text { conseguiram realizar. }\end{array}$ \\
\hline $\begin{array}{l}\text { Wrap up: Pesquisar uma poesia de amor, em inglês, na } \\
\text { internet ou biblioteca. }\end{array}$ & $\begin{array}{l}\text { De uma classe de } 35 \text {, } \\
\text { somente } 2 \text { entregaram! }\end{array}$ \\
\hline $\begin{array}{l}\text { General Comments: achei que eles detestariam a canção } \\
\text { Perhaps Love, como aconteceu com outras salas, entretanto } \\
\text { gostaram! Como acontece em outras matérias, quando se } \\
\text { solicita lição de casa ou pesquisa, poucos são os que fazem. }\end{array}$ & \\
\hline
\end{tabular}




\section{PROFESSOR 2 - ROXANE}

\section{9 e 10 de abril}

Apliquei uma avaliação baseada no conteúdo que o estado pediu para trabalharmos em sala de aula (Jornal de Recuperação). OS ALUNOS utilizaram o jornal e o caderno para fazerem a prova. Poucos alunos têm dicionário de inglês, portanto peguei 20 dicionários da escola e emprestei a eles.

\section{4 de abril}

Fiz a correção da prova e os alunos foram bem. Utilizaram o material dado em sala de aula (caderno + apostilas)

\section{0 de maio}

1. Passei o texto na lousa;

KIM: This is the most incredible place!

JUAN: This is the most incredible place!

KIM: Yeah. It really is. It feels good to be out of the city.

JUAN: It sure does. You know, the trees are just awesome.

KIM: They really are. Have you ever been to Sequoia Park?

JUAN: No. Have you?

KIM: Yeah. I went last year. The trees there are the tallest in the word (SIC)

JUAN: REALLY? I didn't know that.

KIM: Yeah. I had the best time. I mean, it's just the greatest place to hike.

JUAN: WE should go hiking there sometime

JUAN: You're right. We really should.

2. Pedi para que fizessem grupos.

3. Dei pronúncia para cada grupo.

4. Pedi que decorassem o texto

5. Os alunos que conseguirem decorar o texto apresentaram individualmente para mim

6. Alguns alunos acharam ótima a minha idéia. Outros disseram que pretendem fazer a prova.

7. Os alunos que fizerem a apresentação oral eliminaram uma prova.

\section{0 de junho}

Nesta semana, pedi para os alunos apresentarem o diálogo. Disseram que não conseguiram decorar o texto, mesmo os que já fazem curso há quatro anos. Eu acho que eles ficaram com preguiça. Entregaram apenas a prova que eu mandei por e-mail. Fiquei muito triste, porque eu preparei a aula e passei pelos grupos pronunciando o texto.

\section{9 de agosto}

Este bimestre está muito corrido, portanto dividi a proposta curricular em quatro partes, para os alunos. Cada parte valerá 2,5.

O caderno que o governo mandou para os professores está bom. Tem uma prova no final do caderno para aplicar.

Vou tirar xerox do material e dar aos alunos. É impossível passar na lousa. É muita coisa! 


\section{5 de agosto}

Agora estou dando aula para o ensino fundamental também $\left(5^{\mathrm{a}} \mathrm{A}, 5^{\mathrm{a}} \mathrm{B}, 6^{\mathrm{a}} \mathrm{A}, 6^{\mathrm{a}} \mathrm{B}\right.$ e $6^{\mathrm{a}} \mathrm{C}$ e $7^{\mathrm{a}}$ A). Percebi que eles (fundamental) são mais interessados. São muito curiosos e perguntam, quando não entendem a matéria. São muito irriquietos, mas o interesse é bem maior do que no ensino médio.

Eles estão gostando mais de mim do que da outra professora de Inglês. Falam que eu dou matéria e explico.

Tem que ter muita paciência para dar aula no ensino fundamental. Eu entro na sala e espero até que eles fiquem quietos, para eu falar. Digo que levei um desenho pra eles. Aos poucos vão ficando calmos e deixam eu falar e explicar a matéria. Às vezes, explico o conteúdo duas, três vezes, ou até mais.

Passo uma atividade e procuro fazer a correção no mesmo dia. Quando eles terminam a atividade, eu entrego o desenho. Eles adoram e sempre pedem mais. Eu aproveito e sempre faço uma revisão, colocando nos desenhos um pequeno resumo da matéria. Desse modo eu reforço o que foi explicado.

Name:

Teacher:

include

Read the text and complete with verbs:

watching

celebrated

shows

have

ringing

collecting

dressing

\section{Halloween}

Halloween is a tradition (1) on the last night of October, most notably by children (2) in costumes and going door-to door (3) sweets, fruit, and other gifts.

Children (4) a lot of fun with the trick-or-treating. They go door-todoor in their neighborhood, (5) each doorbell and yelling "trick or treat"!

Some other traditional activities ( 6 ) costume parties, ( 7 ) horror films, going to haunted houses, and traditional autumn activities.

The picture ( 8 ) us the "jack-o'-lantern", one of Halloween's most prominent symbols.

Plano de Aula

Tema: Halloween

Tempo previsto: 6 aulas

Série: $7^{\mathrm{a}} \mathrm{A}$

\section{Pre-reading}

- Perguntar aos alunos o que eles sabem sobre o Halloween;

- Pedir aos alunos para fazerem uma pesquisa sobre o Halloween;

- Solicitar aos alunos para lerem as palavras que dão pistas sobre o Halloween como: bat, witch, cat, caldron, cemitery, ghost, etc; 
- Corrigir a pronúncia dos alunos, se houver necessidade, nas palavras que eles procuraram, nas pesquisas feitas por eles.

\section{While-reading}

- Dar aos alunos um handout.

- Ler o texto para os alunos duas ou três vezes.

- Pedir para os alunos prestarem atenção na leitura e completarem o texto com a lista de verbo acima.

- Fazer a correção do texto.

- Solicitar aos alunos para formarem grupos.

- Discutir sobre os preparativos para a realização de uma festa para o Halloween.

- Confeccionar máscaras, fantasias de personagens referentes ao Halloween e enfeites para decorar a sala, no dia 31 de outubro.

- Solicitar aos alunos para fazerem um relatório sobre os preparativos da festa do Halloween.

- Pedir aos alunos para que venham caracterizados, no dia da festa do Halloween.

- Arrumar a sala com os enfeites preparados pelos alunos.

- Convidar os alunos da $5^{\mathrm{a}}$ série e $6^{\mathrm{a}}$ série, para prestigiarem o trabalho elaborado pelos alunos da $7^{\mathrm{a}}$ série.

- Os alunos distribuem doces e balas aos convidados.

- Um grupo conta a história (texto trabalhado em sala de aula) do Halloween para os convidados.

\section{Pos-reading}

- Pedir aos alunos para entregarem um relatório sobre o evento, elaborado por eles e mostrando os pontos positivos e negativos.

- Tirar fotos do evento.

- Mostrar as fotos aos alunos.

- Expor as fotos do evento na escola.

- Enviar fotos aos alunos por e-mail, para que possam guardar de recordação.

- Agradecer aos alunos pela participação e colaboração para a festa do Halloween.

\section{Halloween}

Halloween is a tradition celebrated on the last night of October, most notably by children dressing in costumes and going door-to door collecting sweets, fruit, and other gifts.

Children have a lot of fun with the trick-or-treating. They go door-to-door in their neighborhood, ringing each doorbell and yelling "trick or treat"!

Some other traditional activities include costume parties, watching horror films, going to haunted houses, and traditional autumn activities. symbols.

The picture shows us the "jack-o'-lantern", one of Halloween's most prominent 


\section{PROFESSOR 3 - VIRNA}

\section{4 de abril}

I don't know exactly what you want me to write. Anyway let's start.

As you must know $5^{\text {th }}$ grade students NEVER stop talking. MY $5^{\text {th }} \mathrm{C}$ is one of the worst (I have 4 classes). During some weeks as soon as I turned back to write on the board 5 students started "imitating" plane, car, animals. There was no way I could make them to stop. Fortunately yesterday they changed their behavior (don't ask me why) and at last I COULD TEACH a "great" class. All students "relatively" quiet raising their hands to answer the questions and listening to all I spoke.

The never-end talking problem we have with $5^{\text {th }}$ grade , in my opinion, is due to the fact that $4^{\text {th }}$ grade students are used to only one teacher who "takes care" of them. In the $5^{\text {th }}$ they feel free because there are + or -8 teachers in and out and don't "take care" of them anymore. I want make clear that we have great students in the 5th grade, but unfortunately the "noisy ones" prevent the "good ones" from learning as much as they could. I waste a great deal of my classes trying to solve small conflict, such as: "she showed the finger", "she cut my hair", "he spanked me" "she throwed the paper ball "she said I' m a ..."

\section{1 de abril}

On the other hand based on a course I took last Friday I tried to work with the $7^{\text {th }}$ grade students and "propaganda" in pairs. It was a mess.

\section{5 de abril}

Most of them just talked about other things, played...Some came out with good ideas, with these students I could have continued the work to develop their criticism, learning about the genre "ad " and they could have produced an ad BUT due to because of the mess, I gave up. At least I tried.

\section{5 de maio}

I really don't know what you want me to write. And also if I'm the person you should be contacting. I have started teaching 5 years ago and thinking seriously in giving up. I'm sick and tired of trying to teach and getting nothing. From 40 students, about 6 are interested and I feel I'm a failure because I'm not able to get their interest 


\section{PROFESSOR 4 - ELISA}

Sou professora desde que iniciei meu curso de Letras - muitas vezes sem o registro na carteira de trabalho, uma brecha utilizada pelas escolas particulares. Eu me formei professora de Língua Inglesa mais pela paixão pela língua propriamente dita - desde o colégio. O aprendizado de uma língua estrangeira, para mim, soa como mágico, pois é uma oportunidade de conhecer outra cultura, essa é minha motivação particular.

O ensino de Língua Estrangeira na escola pública é uma batalha árdua, sem vencedores. Hoje esta é minha posição, meu ponto de vista. Entretanto, como profissional, dou o melhor de mim para realizar meu trabalho dentro de sala de aula e, atualmente, através dos cursos de Formação, de Metodologia, de Ensino e de Aspectos Linguísticos, tenho realizado boas aulas que levam ao aprendizado.

Infelizmente, e essa é uma angústia de muitos colegas, a qualidade de nossas aulas é restrita a algumas turmas. O grande empecilho é o grande número de turmas que cada professor deve assumir. Esse foi um dos motivos pelos quais me exonerei da rede estadual de ensino. A outra dificuldade é número de alunos por turma e o número reduzido de aulas semanais. 


\section{PROFESSOR 5 - SONIA}

Leciono nas 7as A, B, C, D e E, em Guaianazes, Zona Leste -.

Em resumo, a escola não tem sala de vídeo, não tem como levá-los à sala de informática e o que me resta é adaptar as atividades em sala de aula mesmo. As turmas são numerosas, de 38 a 40 alunos, eles conversam demais e é difícil prender a atenção deles, mas tem um ponto positivo: os alunos não desrespeitam os professores e o respaldo da equipe técnica é satisfatório.

Iniciei o ano letivo com Grammar: Verbs; não dá para começar com Warm up com dinâmicas, pois a sala é numerosa:

$1^{\circ}$ - Explique o que são verbos, a maior dificuldade desses alunos é associar a aprendizagem de sua língua materna - por exemplo, Verbs, que eles já aprenderam - ao mesmo valor de sjgnificação na LE, pois o que muda é o vocabulário da LE.

$2^{\circ}$ - Repetição de verbos.

$3^{\circ}$ - Pesquisar os verbos no dicionário.

$4^{\mathrm{o}}$ - Memory game: Verbos.

Os procedimentos para as atividades em LE são difíceis, pelo tempo: são 2 aulas de 45 minutos na semana, em dois dias de 1 aula em cada.

Alguns alunos se interessam por aprender, outros são dispersos, acham que a LE não serve para nada. Uma aprendizagem focada na comunicação é impossível, em escola municipal; os alunos adoram conversar, brincar, tudo menos estudar; não têm o hábito, parece que não têm objetivo para o futuro.

\section{$2^{\mathrm{a}}$ semana}

Introduzi mais verbos e novamente Speaking in English e elaborei uma atividade em que fiz duas colunas, uma com 15 verbos e outra com as atividades diárias, e os alunos tinham que uni-las. Por exemplo:
(a) Do
( ) to the radio
(b) Watch
() homework
(c) Listen
( ) $T V$

Eles fizeram as atividades, mas sempre têm 4 ou 5 que não fazem. Exemplos:

- não são alfabetizados

- não se interessam

- só conversam

- muita dificuldade de aprendizagem

\section{$4^{\mathrm{a}}$ semana de março}

1) Escrevi um texto não muito extenso na lousa.

2) Lemos (eu falando e eles repetindo), depois perguntei o que eles entenderam: alguns 10 alunos entenderam tudo do texto; 15 reclamaram que preferiam traduzir o texto com o dicionário; outros 15 falaram que não entenderam nada e que não sabiam de nada.

3) Apliquei uma atividade (W) Reading Activity

a. Questions about text

b. Circle the verbs of the text

Os alunos fizeram as atividades em duplas. Eu organizei os alunos, mesclando os que entenderam com todos os que não entenderam, para ver se estes se interessavam.

Foi difícil a conclusão dessa atividade proposta. 


\section{PROFESSOR 6 - SUELI}

EMEF profa

Prof. Fund II - Inglês

Projeto: Inglês e Informática

Objetivo: Tornar as aulas de Inglês mais significativas aos alunos de uma comunidade extremamente carente de perspectivas profissionais, sociais e culturais.

$1^{\mathrm{o}}$ passo: Escolha da turma $6^{\mathrm{a}} \mathrm{E}$.

$2^{\circ}$ passo: Envolvimento de todos, com diálogos sobre a importância da Língua como possibilidade de comunicação com americanos da mesma faixa etária.

$3^{\circ}$ passo: Apresentação do site: www.studentsoftheworld.info.

Home vocabulário, para compreensão da página inicial.

Investigação do site.

Observação: Foi percebido o interesse em entender o que estava escrito. Intervenção do professor somente para mostrar a familiaridade (cognatas) com a língua materna.

$4^{\text {o }}$ passo: Levantamento de expressões e palavras que possibilitam a comunicação (greetings, introducing yourself).

$5^{\mathrm{o}}$ passo: Escolha de pen-pals, a partir da idade, sexo e foco de interesse em comum.

$6^{\circ}$ passo: Elaboração de texto a ser digitado $(e-$ mail $)$.

$7^{\circ}$ passo: Enviar e-mail.

Observação: Em sala de aula, nos primeiros minutos, os alunos retiram dúvidas e recebem orientações para cada etapa.

$8^{\circ}$ passo: Verificação constante do e-mail, para ler a resposta dos new pen-pals.

Observação: Os alunos já começam a perguntar o que acontecerá, caso não recebam a resposta.

Indisciplina

Acreditamos que alguns casos de alunos ainda indisciplinados tendem a diminuir, assim que os demais colegas começarem a comentar sobre os amigos estrangeiros.

Atividades desafiantes tornam as aulas mais interessantes. 


\section{PROFESSOR 7 - GARY}

Em qualquer atividade passada para os alunos, a grande dificuldade que eles alegam ter é o desconhecimento de um vocabulário razoável para entendimento de qualquer texto.

Invariavelmente somos solicitados a colocar na lousa a tradução de quase todas as palavras. Uma estratégia um tanto diferente da tradicional que usei nesta semana foi: após passar na lousa a sinopse do filme Crash, solicitei que sublinhassem todas as palavras já conhecidas e também as cognatas (aquelas parecidas ou iguais ao português). Assim sobrou um número reduzido de palavras desconhecidas (aquelas que são bem anglo-saxônicas mesmo)

Após passar essas palavras com as traduções, pedi que, em duplas, fizessem um resumo (em português) da sinopse do filme. O trabalho ainda não foi completado (terão mais uma aula para completar), mas percebi que os alunos ficaram surpreendidos com a quantidade de palavras que sabem e motivados para trabalharem em duplas, na geração de um resultado mais envolvente.

OBS: Experiência com $2^{\circ}$ ano do ensino médio.

EE

\section{Experiência em uma classe de $7^{\mathrm{a}}$ série:}

Passei uma atividade semipreparada em Xerox (cada aluno tinha sua cópia). Deveriam preencher os espaços, a partir de 2 ou 3 opções, com suas características pessoais (masc-fem; alto baixo; gordo-magro, etc). Permiti que trabalhassem em duplas ou trios. Estavam, no entanto, muito barulhentos, e vários deles - sem vontade de fazer o exercício - ficavam "passeando" pela sala ou levantando para jogar papel no lixo.

Alertei-os por várias vezes de que deveriam ficar em silêncio. Sem muito sucesso em acalmar os mais ruidosos, fui conferir o que eles já haviam feito do exercício; dois nem tinham começado e eram dos mais ruidosos. Coloquei-os para fora da sala e ameacei os demais que, se não melhorassem o comportamento e não fizessem o exercício, outros seriam postos para fora também. O comportamento melhorou depois disso.

Acho que tenho alguma dificuldade de lidar com crianças em idade de puberdade $\left(7^{\mathrm{a}}\right.$ e $8^{\mathrm{a}}$ séries). Há, no entanto, um ponto que acho importante citar: minhas aulas nas 7as séries ( 2 classes) são sempre as últimas do dia para os alunos. E, o pior, uma delas é na sexta-feira, quando os alunos já estão de "saco cheio" e loucos para ficarem livres dos professores e curtirem o fim de semana. Acredito que a pouca preocupação em fazer as atividades e, mesmo, o barulho excessivo que fazem deve-se a isso também: últimas aulas da semana.

Você já pensou nisso, minha amiga?

Kisses, G 


\section{PROFESSOR 8 - SOFIA}

Num primeiro momento, procurei conversar com os alunos sobre uma nova dinâmica que usaria com eles, durante as aulas. Foram bastante receptivos. Organizei-os em círculo e fizemos uma dinâmica na qual cada um pôde interagir melhor com o professor e os colegas. Percebi que o ambiente ficou mais tranquilo, que eles ficaram mais curiosos e a dinâmica agradou. O tema da aula foi COLORS e, após cada um reconhecer as cores, ao final da aula tinham que formular uma frase com uma delas. O objetivo final será construir um texto coletivo, a partir de uma abordagem comunicativa. 


\section{PROFESSOR 9 - FLORA}

Alunos do fundamental II, ESPECÍFICAMENTE DA $8^{\text {a }}$ SÉRIE (minha turma), não se interessam muito pela língua inglesa. Eles a acham muito difícil e acreditam que não precisarão aprender no futuro. Poucos são os interessados e que têm noção ou já sabem.

A turma é totalmente (de modo geral) desinteressada.

Alunos do ensino médio (1as e 3as séries): acham a língua muito difícil e têm pouco interesse nas aulas de Inglês.

8as séries: houve uma pequena melhora. Após dar uma prova de recuperação para alguns alunos, percebi uma melhora não muito grande. No começo, os alunos estavam inseguros, pois estavam sem professora de Inglês; tiveram 2 ou 3, até eu pegar as aulas desta turma.

Ainda há alunos que não querem aprender inglês ou que acham a língua muito difícil.

1as séries EM: noto também que teve uma pequena melhora no aprendizado. Ainda há insegurança da parte deles, mas já vejo que uma certa parte se interessa.

Infelizmente existem alunos que vão para a escola para bagunçar, sem interesse de aprender.

A maioria dos alunos fala que não aprendeu o Simple Present, acredito que a maioria apagou da memória. $\mathrm{O}$ interesse é pequeno.

3as séries EM: uma parte desses alunos foi aluno meu no $1^{\circ}$ ano. Vejo também insegurança (ainda) e desinteresse. Estão acostumados com traduções, perdem muito tempo traduzindo frases, textos. Tento, de uma maneira, colocar na mente desses alunos que não precisam traduzir tudo; eles precisam, sim, é tentar entender de um modo geral do que trata o texto, pois já sabem um número razoável de palavras (os significados em português) 


\section{PROFESSOR 10 - MARIANA}

Trabalho como professora há 8 anos e atualmente trabalho em 4 escolas, no mesmo bairro onde moro, Guaianazes. Até o ano passado, as escolas eram bem próximas da minha casa e isso facilitava o trabalho com a comunidade. Este ano estou trabalhando um pouco distante, a 20 minutos da minha casa, na cidade Tiradentes; uma escola enorme e muito bem organizada, cujo nome é xxxxxx O que eu mais gosto lá são os coordenadores, pessoas politizadas e que se preocupam com a função da escola na comunidade e com o verdadeiro sentido da Educação.

Outra escola em que trabalho à noite, com EM e 8as séries, é a E.E. xxxx. Ela fica vizinha da minha casa e nela estou há três anos. Gosto muito dos alunos de lá, mas não me identifico com a Direção, que é muito ortodoxa e não sabe tratar as pessoas.

A esta escola vou às segundas, terças e quartas à noite e quinta de manhã. No xxxx vou às segundas, terças e quartas, no período das $7 \mathrm{~h}$ às $13 \mathrm{~h} 30$.

Trabalho também no Céu xxxx, às quintas e sextas, à noite, das $20 \mathrm{~h}$ às $22 \mathrm{~h}$, e na EMEF xxxxx, um dia apenas, 2 aulas, na segunda à tarde.

Gosto de trabalhar com formação de grêmio na escola, porque o grêmio faz surgir lideranças, faz com que o aluno goste da escola e transforma o aluno em protagonista do seu tempo. Vejo as escolas da periferia não apenas como um lugar de transmissão do conhecimento formal, mas como um espaço de convivência significativo, onde são depositadas todas as esperanças de transformação e mudança de vida.

Com relação à minha postura como professora, penso que eu deveria ser mais exigente e durona; às vezes acho que sou muito "boazinha" e isso atrapalha. Eu converso muito com os alunos e me apego muito; sou uma amiga deles; com o ensino médio e as 8as, é bom; mas com as 5 as séries tenho que ser mais durona. 


\section{PROFESSOR 11 - ISADORA}

Houve um dia desta semana que não tivemos água na escola. Aproveitei a oportunidade, em meio a reclamações dos alunos, e comecei a conversar sobre higiene.

Já fazendo o pré-dicting, lembrei de um texto - Hygiene in Space - e perguntei o que eles sabiam sobre astronautas, planetas, como eles imaginavam a rotina diária deles e de um astronauta, comparando alimentação, hábitos na Terra e no espaço.

Ficaram supercuriosos e completei, falando sobre as experiências do astronauta brasileiro, conhecidas quando ele esteve no programa do Jô Soares.

Finalizando, coloquei o texto Hygiene in Space no quadro e pedi que fizessem a tradução. Coloquei as palavras mais difíceis traduzidas. Os alunos adoraram conhecer os detalhes e fazer a tradução.

O assunto polêmico, "falta d'água", que os remetia a pensar em "ir para casa" rendeu uma aula superlegal. 


\section{PROFESSOR 12 - CECI}

$7 \mathrm{a}$

Reading and Comprehension

Text: THE 8 millenium Development Goals

Iniciei a aula, pedindo que fizessem leitura silenciosa do texto The 8 millenium goals e grifassem as palavras que dificultavam a compreensão do texto. Pedi também que observassem bem a figura que ilustra cada um dos 8 tópicos e, enquanto liam, fiz a chamada. Depois, li o texto em voz alta, sem discuti-lo; apenas lemos.

Em seguida, levantamos as dificuldades do vocabulário e tentamos concluir cada um dos 8 tópicos, juntando opiniões e checando as possibilidades.

Ao final da aula, propus um questionário que deveria ser começado em sala de aula e terminado em casa.

\section{Reading and Comprehension:}

Text: The 8 Millenium Development goals

Retomamos as principais mensagens de cada um dos tópicos e as comparamos com a realidade brasileira. Em seguida, corrigimos oralmente as questões. Paramos na questão 7. O barulho das conversas paralelas e o fato de a professora ter que chamar a atenção quanto à importância da participação oral de maneira mais séria nos fez perder um tempo relevante.

Lição de casa: estudar o questionário para a prova. 


\section{PROFESSOR 13 - SABRINA}

A maior dificuldade de ensinar a matéria de Inglês é o desinteresse, a falta de compromisso dos alunos com os estudos, mesmo sabendo que é necessário saber o básico para um bom emprego ou para seu aperfeiçoamento extracurricular. Nós ficamos tentando achar uma estratégia para atrair o interesse pela matéria. Quando traçamos estratégias e métodos para as nossas aulas, vemos que não atingimos $100 \%$ e sim $30 \%$ dos alunos, e é aí que nos decepcionamos pelo nosso fracasso ...mas nada como uma aula após a outra

Agora os alunos começam a se interessar, pois estamos com recursos que provêm de esforços próprios, para que não fique só na mesmice de caderno x lousa x prova $\mathrm{x}$ atividade. Agora usamos brincadeiras confeccionadas por eles, para que tragam um ensinamento maior e o interesse aumente para todo o lado: aluno-professor e/ou professor-aluno. Eles, assim, começam a perguntar mais, a fazer um debate sobre um tema atual, um vídeo, um filme, um clip, uma música, tudo aquilo que possa entretê-los na aula

Nessa aula, tive dificuldade de seguir o cronograma - expor o tema, o desenvolvimento -, porque não tinham visto o trabalho sem pressão e/ou cobrança para com a disciplina, mas nada que, com 3 aulas, não consigam superar o medo de encarar um desafio. A atividade era de autobiografia, mas com fotos, relatos familiares, desenhos antigos que comprovassem a autenticidade dos fatos... Bem, dos 42 alunos, 15 estudantes conseguiram atingir o objetivo, mas a luta continua, desde que você mostre o caminho e por onde andar ( $7^{\mathrm{a}}$ série).

$\mathrm{Na} 5^{\mathrm{a}}$ série, o trabalho é um pouco maior, pois o uso do dicionário e a dificuldade de identificação do que se pede, mesmo tendo acabado de explicar e tirado dúvidas, ainda resistem, pois se negam a copiar, fazer o diferente, como ilustrações, pinturas.

A prática do que se aprende ainda é o maior desafio para todos, mas não será, se todos ficarem juntos e não desistirem de repassar o conhecimento novo e inovador, fazendo com que os alunos aprendam a valorizar o novo e a encarar o desafio de aprender brincando. E, quando houver interação de todos, teremos atingido pelo menos $35 \%$ a $63 \%$ das metas, através de estratégias e materiais, como recurso-base para um bom ensino-aprendizagem. 


\section{PROFESSOR 14 - MARISTELA}

Os alunos da $5^{\mathrm{a}}$ série vêm da $4^{\mathrm{a}}$ série curiosos por aprender a língua inglesa. Participam, falam, repetem, e gostam de aprender coisas novas. Porém, por uma questão cultural, não gostam de ler. A leitura encontra um bloqueio muito grande para a língua materna, o português, e se torna ainda maior para a língua estrangeira.

Levando em conta que a personalidade das classes reflete a personalidade dos alunos como grupo, faço esse perfil dos alunos agora:

$5^{\text {a }} \mathrm{C}$ : Trata-se de uma classe agitada, com problemas de disciplina. Os alunos têm dificuldade para se respeitarem, com brincadeiras violentas, o que às vezes leva a brigas.

$5^{\text {a }}$ D: Trata-se de uma classe participativa, que não possui problemas de disciplina, respondendo sempre as perguntas. Nesta sala, dois alunos já fizeram curso de Inglês e, como eles participam das aulas, os demais se sentem motivados a responder, para mostrarem que também sabem algo.

\section{PROFESSORA 15 - LYDIA}

Eu trabalho com uma turma de $5^{\text {a }}$ série, com 38 alunos frequentes. É difícil, pois é uma turma muito falante, sem limites. Já tentei apresentar vários trabalhos, mas sem retorno, pois eles dizem que não gostam de Inglês. São 2 aulas semanais.

O último trabalho que fiz com minha turma foi saber os nomes das partes do corpo humano. Resolvi trabalhar em grupos, porque iam ser usados dicionários, que não havia em número suficiente. Dividi a turma em grupos, expliquei o que era para ser feito, passo a passo, falei que iam ser usadas revistas, cola e tesoura. Pedi que procurassem uma gravura de homem ou mulher, de corpo inteiro, que recortassem e colassem na folha de sulfite. Mas, como sempre, eles fogem do foco de trabalho e tudo vira uma bagunça: um quer a revista do outro; começam a ver outra foto. O trabalho, que deveria ter duração de duas aulas, fica para a próxima. Bem, resolvi fazer esse trabalho com eles devido a uma pergunta de uma aluna: perguntou por que leg era uma calça, sendo que, em inglês, era perna. 


\section{PROFESSOR 16 - AILTON}

Dar aulas de inglês na escola pública estadual não tem sido uma tarefa fácil. Primeiro, pela falta de material e, segundo, pelo desinteresse dos alunos. Eles conversam muito, o que torna difícil o ensino de Inglês.

Eu dou aulas somente no ensino médio. Alguns anos atrás, já lecionei também no ensino fundamental. Parece que, no ensino fundamental, como o Inglês é uma novidade para eles, há uma receptividade maior. Eles repetem as palavras e as frases. No ensino médio, têm vergonha de repetir as frases. Muitos acham difícil aprender, porque muitas vezes não tiveram uma base anterior.

Há uma dificuldade, também, pelos níveis diferentes de conhecimento, em uma sala de aula. Muitas vezes, temos alunos que sabem bem a língua e outros que não têm conhecimento nenhum. Para aqueles que já sabem um pouco, determinadas atividades são muito fáceis, já para os outros são muito difíceis. Então ambos perdem o interesse.

Vamos ao que funciona: trabalhar com textos curtos, com perguntas em português e algumas em inglês. Os assuntos não podem ser muito longos, senão eles perdem o interesse. As atividades têm que ser cobradas no mesmo dia em que foi passado o texto ou a parte gramatical. Infelizmente o speaking tem sido pouco trabalhado, em virtude das dificuldades mencionadas acima. Quando é possível trabalhar com o speaking, eles gostam e o interesse aumenta. 


\section{PROFESSORA 17 - JACI}

ATIVIDADE 2

Grupo: $3^{\circ}$ ano - ensino médio

Tempo: 45 minutos

Duração da Atividade: 2 aulas

Objetivo: Saber descrever características e qualidades físicas e intelectuais.

Describes about you.

Use: EYES/HAIR/HEIGHT/WEIGHT/AGE/PERSONALITY/SKIN/OPINION

\begin{tabular}{|c|c|c|c|c|c|c|}
\hline$?$ & & & & & & \\
\hline $\begin{array}{c}\text { I AM... } \\
\text { HE IS... } \\
\text { IS HE...? } \\
\text { ARE } \\
\text { YOU? }\end{array}$ & $\begin{array}{l}\text { young } \\
\text { in her teens } \\
\text { in his } \\
\text { twenties } \\
\text { middle-aged } \\
\text { old }\end{array}$ & \begin{tabular}{|c|} 
pretty \\
beautiful \\
gorgeous \\
attractive \\
handsome
\end{tabular} & $\begin{array}{l}\text { tanned } \\
\text { pale } \\
\text { (She's got } \\
\text { dark/fair } \\
\text { skin) }\end{array}$ & $\begin{array}{c}\text { short } \\
\text { tall } \\
\text { average } \\
\text { height }\end{array}$ & $\begin{array}{c}\text { skinny } \\
\text { slim } \\
\text { thin } \\
\text { chubby } \\
\text { plump } \\
\text { fat/heavy }\end{array}$ & $\begin{array}{c}\text { friendly } \\
\text { lovely } \\
\text { nice } \\
\text { shy } \\
\text { outgoing/sociable }\end{array}$ \\
\hline
\end{tabular}

\begin{tabular}{|c|c|c|c|c|c|c|c|}
\hline$?$ & & & & & & & \\
\hline $\begin{array}{c}\text { I'VE GOT } \\
\text { SHE'S } \\
\text { GOT } \\
\text { HAS SHE } \\
\text { GOT...? }\end{array}$ & $\begin{array}{c}\text { short } \\
\text { shoulder- } \\
\text { length } \\
\text { long }\end{array}$ & $\begin{array}{c}\text { straight } \\
\text { wavy } \\
\text { curly }\end{array}$ & $\begin{array}{l}\text { blond } \\
\text { fair } \\
\text { red } \\
\text { brown } \\
\text { black } \\
\text { dark }\end{array}$ & $H A I R$ & $A N D$ & $\begin{array}{c}\text { blue } \\
\text { green } \\
\text { brown } \\
\text { black } \\
\text { dark }\end{array}$ & EYES \\
\hline
\end{tabular}




\section{LESSON PLAN}

Objetivo: Saber descrever características e qualidades físicas e intelectuais.

\section{Pre-Speaking:}

Mostrar figuras de várias pessoas e explorar detalhes.

Quais são as características físicas das pessoas mostradas?

\section{While-Speaking:}

1. Pedir aos alunos para que descrevam suas características e qualidades físicas e intelectuais.

2. Em pares os alunos, deverão descrever oralmente o colega.

\section{Post-Speaking:}

Homework - Escrever uma composição sobre o colega entrevistado em sala de aula.

\section{Lesson Report:}

Não tiveram dificuldades para executar a atividade. Acredito que seja porque, hoje em dia, a primeira coisa que as pessoas veem é a nossa aparência física, que também é a forma de nos apresentarmos ao mundo exterior. Participaram ativamente.

Achei que foi uma atividade dinâmica, com um tema interessante.

\section{Lesson Journal:}

O tema possibilitou mais atenção e tranquilidade na classe. Essa disposição impediu que os mais bagunceiros levantassem a toda hora. Como o assunto foi interessante aos alunos, ficou mais fácil para se comunicarem em inglês comigo. 


\section{ANEXO 2 - RELATOS ORAIS (TRANSCRIÇÃO DE ENTREVISTAS GRAVADAS EM ÁUDIO)}

\section{PROFESSOR 10 - MARIANA (M)}

Pesquisadora: Pode falar sobre a última aula de Inglês que você deu?

M: Aula, aula, assim, não houve muitas ontem, só uma reunião pedagógica. Ontem houve uma reunião pedagógica no período da noite; o principal objetivo dessa reunião, acho, foi informar que não haverá mais as auxiliares que nos ajudarão e que a escola está passando por problemas de drogas?

Então foi sugerido, pelo que deu para perceber no final da reunião, que a Direção está em apuros e, assim, entre aspas, está precisando de ajuda dos professores; precisa de sugestões. Como eu já moro num bairro onde é constante o número de drogas e estou acostumada a lidar com essa situação, sugeri que a gente levasse pra escola grupos de alunos jovens que se identifiquem com essas pessoas que estão passando pelo problema; que se identifiquem e que, através desse grupo, a gente dê sugestões para os alunos, para não trazerem esse tipo de problema para dentro da escola. E que respeitem o espaço dos outros que querem aprender, porque, no caso desta escola, é uma turma de EJA à noite e tem os senhores que querem aprender; pararam de estudar há muito tempo e vão lá, porque querem aprender, mas há os jovens que vão lá para se divertir e esses que vão lá para, além de atrapalhar, trazerem esse problema da droga. Eles usam a droga e chegam drogados à sala de aula; querem sair assim, querem sair a qualquer momento, se tornam agressivos. Então, a minha sugestão foi essa: que levássemos esse grupo de dança de rua e do movimento hip hop, porque, através desse movimento, eles podem se conscientizar de que a escola não é um espaço adequado para usar a droga. E também através do hip hop e das artes que o hip hop propõe, como a dança, arte da grafitagem, o desenho. E o basquete faz parte também.

Pesquisadora: Ah! O esporte...

M: O esporte. Dentro do hip hop, através dos 4 elementos do hip hop, o jovem vem a extravasar esse sentimento que existe dentro dele, sentimento de angústia ou de repressão que está vivendo...

Como eu conheço alguns meninos que dançam as danças de rua em outra escola em que eu trabalho, na comunidade em que eu vivo, então vou convidá-los a irem até esta escola em que eu estou enfrentando problemas, para conhecerem esses meninos e tentarem integrá-los ao grupo. Vamos propor, também, para a Direção que abra espaço dentro da escola, para realizar alguma atividade com esses alunos. Essa é uma das sugestões que vieram também na reunião. Há dois anos, a escola em que eu estava trabalhando estava com dificuldade não só pelas drogas, mas também pela indisciplina, muita indisciplina. A gente não conseguia controlar, os alunos iam para quebrar a escola, para tirar sarro dos professores; não tinham vínculo com a escola, parecia que não gostavam dela.

Aí comecei a trabalhar e eu morava, eu moro, lá nessa comunidade, e comecei a..eu montei um grupo de teatro com ex-alunos da escola que faziam trabalho na igreja. Montamos um grupinho de teatro e ficamos trabalhando por 2 meses numa peça. E as pessoas que participaram foram, muitos deles, alunos que estavam dando problema na escola, e o teatro serviu como forma de eles extravasarem o que estavam pensando. E houve um amadurecimento no final da apresentação; eu senti que houve um amadurecimento de parte 
dos alunos e, no ano seguinte, eles mudaram totalmente o comportamento, se apegaram à escola, passaram a gostar mais dela, e isso serviu de exemplo para os outros.

Agora existe problema de disciplina, mas não tão grande como antes, e eles passaram a respeitar e a gostar. E, fazendo esse trabalho, eles acabam se aproximando mais da gente, é uma forma de aproximação, e formam um vínculo muito grande com a gente; é um carisma que eu acho importante... enfim, um relacionamento afetivo professor-aluno-escola em geral, entre todos os professores e funcionários. É importante que vejam a escola como um espaço do qual participem e do qual gostem, um espaço de transformação da vida deles.

\section{PROFESSOR - JULIAN (J)}

$\mathrm{O}$ que eu vejo como uma das maiores dificuldade de se ensinar a Língua Inglesa, na escola pública, é a questão da falta de material de apoio para o aluno, no caso, o livro didático.

Já estou há doze anos na rede e o único livro com que eu tentei trabalhar foi um adotado, e nem todos os alunos conseguiram adquirir, por questões financeiras, com recursos próprios: não tinham disponibilizado até mesmo um único dicionário, que poderia acompanhar, que poderia ajudá-los; é difícil adquiri-lo.

Apesar de que, este ano, já está bem melhor porque, no ano passado, com o projeto Ler Escrever, as escolas receberam um kit de inglês, embora só dez exemplares de cada livro. E alguns dicionários também chegaram às escolas, e isso é o que tem facilitado, mesmo com uma pequena quantidade de exemplares, nosso trabalho, minimizando aquelas questões relacionadas ao material de apoio.

Pesquisadora: Não tem sequência de uma aula para outra? $\mathrm{J}$ : Ah, sim! A sequência a gente elabora a partir do nosso plano e também revendo a questão da Proposta Curricular. Nós temos os pressupostos da Proposta e temos que procurar atender um pouco aquilo que foi traçado e determinado pela Secretaria da Educação. Claro que, em consonância com o trabalho do professor, tudo foi passado para as escolas, nós analisamos, fizemos algumas alterações porque víamos que havia coisas que não tínhamos condições de cumprir, que inviabilizavam todo o trabalho, por exemplo, trabalhar com a sala de informática, visto que o professor de Informática é um e o professor de Língua Inglesa é outro, ou seja, são aulas diferentes. Não é como outros anos, em que o professor trabalhava com o professor de Informática, mas então ele levava seus alunos durante a sua aula e lá, na sala de informática, o professor de Informática auxiliava o de Inglês a desenvolver as atividades com os alunos. Eu achava isso mais interessante do que hoje, mesmo porque, muitas vezes, o professor de Informática não tem esse conhecimento da Língua Inglesa, então como vai orientar esses alunos? Eu sei que tem uma infinidade de coisas que se podem aproveitar, que se podem desenvolver na informática, mas ainda vejo essa deficiência.

Pesquisadora: $\mathrm{Na}$ escola da Professora Leontina..., a professora dá uma musiquinha em inglês e colocam em vídeo, os alunos põem desenhinho e fazem um videozinho separadamente.

J: Ah! Isso na sala de informática?

Pesquisadora: Na sala de informática, e elas já trazem uma música.

J: Certo. Existem recursos que podem ser utilizados, mas é muito pouco ainda, pelo menos eu acho. Há uma proposta, para o próximo ano, de termos material de apoio, o livro de Inglês, digamos assim, porque se a gente vai fazer qualquer curso de Inglês, até mesmo aqui nesta entidade, precisamos comprar o material, para que possamos acompanhar as aulas, e isso não 
é diferente para os nossos alunos que estão iniciando o ensino da Língua Inglesa. Como é que o aluno vai aprender, sem ter um material dele, que ele possa usar, que possa usufruir?

Pesquisadora: Quais são a propostas que vocês recebem, os objetivos que têm alcançado com essas aulas? Tem alguma coisa clara a esse respeito?

J: Olha, tem sim. A proposta está bem elaborada, apesar de um pouco distante da realidade do nosso aluno, porque, o ensino brasileiro, não só o da rede pública, mas todo ensino brasileiro, tem uma defasagem muito grande. Ainda hoje, eu vi na manchete do jornal que o governo do estado diz que a escola de Primeiro Mundo, no Brasil, vai ser pra 2030, ou seja, até 2030 eu já estou aposentado, não vou ver essa escola e gostaria de trabalhar nessa escola de Primeiro Mundo. Não sei em qual jornal, mas está estampado; passei em frente à banca, vindo para cá e observei isso. Aí fiz as minhas contas e quer dizer que eu não vou participar dessa escola de Primeiro Mundo aqui no $\mathrm{Br}$, como trabalhador...hahahaha..., mas a gente espera que muitas coisas possam melhorar, principalmente no tocante ao ensino da Língua Inglesa, que é uma língua universal à qual todos têm que ter acesso, para poderem conhecer novas culturas, pelo mercado de trabalho, pelas exigências que a gente tem hoje, no dia a dia.

\section{PROFESSOR 7 - GARRY (G)}

$\mathrm{Na}$ verdade, isto aqui foi proposto pela Secretaria da Educação... eheheheh.... com umas atividades.

Pesquisadora: Isso o quê, exatamente? Pense que eu não sei nada direito....

G: É que a gente foi solicitado, no planejamento no início deste ano, a fazer um trabalho que, na verdade, veio pronto...umas propostas para trabalhar com os alunos em todas as matérias, para que eles tivessem maior capacidade de entender, de raciocínio do que parece o resultado das avaliações que foram feitas... aí, os alunos, de um modo geral, tinham uma grande dificuldade de interpretar textos. Não leem, claro, numa língua estrangeira. Ainda é pior pra entenderem enunciados de questões, até matemáticas, entender o que o professor de Geografia pede, uma explicação.

Pesquisadora: Dificuldade de leitura?

G: De leitura.

Pesquisadora: Eles não conseguem interpretar, só decodificar?

G: Exatamente. $\mathrm{O}$ contexto das coisas eles não conseguem entender, assimilar e trabalhar aquilo. O resultado foi pífio, né? O estado de SP teve níveis parecidos com o do Maranhão, nada contra os maranhenses, mas SP é o estado mais rico da federação, certo? Portanto, deveria ter uma qualidade de ensino, uma educação. E que os alunos tivessem um desempenho muito melhor do que o que foi registrado, então, o governo do estado, preocupado com isso, fez esse trabalho e solicitou que todos os professores trabalhassem essa habilidade. E os professores de LE também tiveram que fazer isso.

Pesquisadora: Como vocês vão fazer? É uma questão de alfabetização. Aí, como é que é, que série é, que ano...? 
G: Primeiro grau e segundo grau. Fundamental, né? E o ensino médio.

Pesquisadora: Eles já deveriam estar lendo bem. Não estão? Deviam estar lendo bem...

G: Não estão. Eles têm sérias dificuldades de entendimento.

Pesquisadora: E como você vai resolver isso na sala de aula de Inglês?

G: Então, uma das coisas que eu utilizei - e que foi utilizada também em outro trabalho, no início do ano, com a Secretaria da Educação - foi o trabalho com cognatos, principalmente os cognatos, palavras que são parecidas ou iguais ao português, a língua nativa ou as que eles aprendem, que eles têm, de modo que eles possam - pudessem - ter uma visão geral, analisando as palavras que são parecidas, que são cognatas. O professor reforçaria mais aquelas [palavras] que são de origem anglo-saxônica e muito diferentes das nossas latinas. E, então, fazer uma espécie de mescla dessa situação. O resultado parece até que foi um pouco razoável, porque eles puderam, pelo menos, se preocupar com o texto, porque mesmo as palavras mais difíceis, que seriam as palavras inglesas mesmo, de origem saxônica, algumas delas são conhecidas, são comuns, porque eles veem isso há muito tempo. As palavras simples, desde as coisas que se usam mais, como o to be, as coisas do cotidiano, muitas coisas eles conhecem. Parentes de familiares, essas coisas eles já conhecem, mas qualquer outra palavra mais estranha, realmente fica [mais difícil]; eles sentem muita dificuldade; eles querem, realmente, ter o equivalente da língua portuguesa. Sem o equivalente, sem a tradução, eles parecem ficar travados, não conseguem...

Pesquisadora: Por que você acha isso?

G: Isso porque eles têm o Inglês [na escola] e nunca foi dada muita importância ao enfoque que era dado, principalmente no primeiro grau, não sei se continua assim. O enfoque no Inglês não é visto como uma matéria, mas como uma atividade.

Pesquisadora: Mas agora é obrigatório?

G: Agora e obrigatório, mas permanece essa ideia. Permanece essa ideia e o aluno que chega ao ensino médio não tem nenhum vocabulário, ou ele é muito pequeno, muito reduzido e, quando você começa a trabalhar com alguns textos um pouco mais avançados, ou com uma conotação científica, coisas do cotidiano ou coisas, assim, com que o mundo está preocupado, com preservação da natureza, sustentabilidade, aquecimento global, apesar de ter muitos cognatos, existem muitas palavras técnicas que eles desconhecem.

Pesquisadora: Em português?

G: Mesmo em português. Então, eles dependem muito de uma tradução. Então, o professor do estado, principalmente, não tem muito recurso, e não há nem dicionários disponíveis que eles possam consultar. O professor fica sobrecarregado porque, praticamente, ele tem que colocar na lousa todas as palavras desconhecidas.

Pesquisadora: Em quantos anos [séries] você leciona Inglês?

G: Tenho duas sétimas, duas oitavas, dois primeiros do ensino médio, quatro segundos e três terceiros, tenho treze classes, 26 aulas por semana de Inglês. Também [tem] uma outra 
conotação que eu acho que é a carga horária de aulas semanais. É muito pequena [considerando] a importância que o inglês tem na vida, hoje, do brasileiro, como uma língua universal. Deveria ter pelo menos três aulas por semana e são só duas, e você sabe, no estado, à noite principalmente, já tem 10 minutos a menos de aula. São só 40 minutos. Até todo mundo se ajeitar, fazer chamada, na verdade, você fica com uns 25, 30 minutos, realmente. É muito pouco, os recursos são muito reduzidos. Praticamente, o professor tem nada, quer dizer, tem sua boa vontade, de passar na lousa, mas, inclusive o material didático, o governo não fornece para algumas matérias. Fornece para o Inglês, [mas] eu nunca vi, nunca tive; então, depende muito do professor em reproduzir material, tirar xerox. Às vezes, ele paga do próprio bolso, porque a escola não tem condições.

Pesquisadora: Material didático, para você, significa o quê, exatamente? O livro e o caderno?

G: É o livro, principalmente livro [de] textos.

Pesquisadora: Não tem livros de Inglês?? Não tem livros de Inglês?

G: Não tem... não tem....

Pesquisadora: De onde você tira os textos?

G: Eu... O professor tem o livro, né? Mas ele depende, praticamente, de colocar na lousa. Toda atividade escrita é passada na lousa. Aí os alunos reclamam do professor, mas é difícil, porque realmente é uma língua diferente. Eles têm dificuldade até de copiar as palavras. Tem que copiar devagar porque senão...

Pesquisadora: Mesmo na quinta série?

G: Mesmo.

Pesquisadora: No ensino médio você nota isso também?

G: Também. Realmente, é uma deficiência muito grande...

Pesquisadora: Da escrita das palavras em inglês? Ou você nota que é [da escrita em] inglês e português?

G: Português também, mas quando se trata de uma língua estrangeira, a dificuldade é multiplicada.

Pesquisadora: Uma simples palavra?

G: São muito dependentes do professor...

Pesquisadora: Copiam da lousa?

G: Copiam da lousa.

Pesquisadora: Isso leva um tempo? 
G: Leva muito tempo, é realmente muito complicado. Claro que existem algumas exceções, tem alguns alunos que gostam da matéria ou por uma razão ou outra, fizeram algum cursinho, mesmo no bairro... Alguém que se esforça por vontade própria... Eu tenho, por exemplo, um aluno no terceiro ano que consegue manter um nível de conversação razoável comigo, mas ele é uma exceção... Na verdade, na minha aula, coitado, ele fica desestimulado, porque o que eu passo pra ele, ele já sabe há muito tempo.

Pesquisadora: Ele não pode ajudar os outros?

G: Ele ajuda... ele ajuda, mas isso também é limitado. Uma outra dificuldade é a classe numerosa, eu tenho 40, 45 alunos por classe, então, realmente, é um pouco complicado.

Pesquisadora: Como você consegue disciplinar os 45 ? Tem muita conversa paralela?

G: Tem...tem...no caso do noturno, com os colegiais, com o ensino médio, é um pouco mais fácil, é um pessoal um pouco mais adulto. Eu já estou na escola há algum tempo; tenho, assim, uma penetração legal com eles, eles me têm em respeito. Eu sou um cara que costuma brincar na hora certa, não sou um professor, apesar da enorme diferença entre mim e eles, né? Eu levo a classe numa boa, num ambiente que eu acho legal.

Pesquisadora: não tem nada a ver com a idade?

G: Não, nada disso.

Pesquisadora: Muito pelo contrário?

G: Muito pelo contrário. Tem professores mais jovens lá que são até mais sisudos... que se fazem...

Pesquisadora: Personalidade.

G: Exatamente! Então, isso me ajuda, porque, às vezes, quando eu chamo a disciplina, tenho que falar um pouco mais alto, dar umas batidas na mesa. Porque, às vezes, o pessoal está num alarido muito grande com o pessoal do fundão e nem me ouve, mas, quando chamo, normalmente a resposta é positiva e eu consigo levar numa boa. É mais fácil levar os adultos do que levar as crianças da tarde que estão naquela idade de puberdade, 13, 14 anos. Aí é realmente complicado, né? O pessoal da $8^{a}$ série, principalmente, está nessa fase de mudança, é muita vitalidade e o corpo se transformando. E as classes são mistas. Então já [viu], né?

Pesquisadora: Namoricos...

G: Namoricos, etc. Tudo isso dificulta, mas o pessoal da noite, o pessoal do ensino médio já é mais fácil, e também a classe é um pouco menor. Eu tenho algumas classes com 37, 38 [alunos], mas à tarde, o pessoalzinho da $7^{\mathrm{a}}$ e $8^{\mathrm{a}}$, são classes de 40 alunos, mas, por exemplo, o material que nós recebemos... Cada professor recebeu um livrinho muito bem feito, muito bem bolado, pessoal especializado...

Pesquisadora: Os PCNs? 
G: É. Baseado nisso, na CENP também, mas parece que eles não têm conhecimento da realidade da escola. A proposta é excelente, o que falta é recurso. Por exemplo, o filme Crash tem lá uma sinopse muito bem feita pra você passar: tem assunto de intolerância, de racismo, de discriminação racial, tem um elenco forte, a trama é [tão] forte que é legal você discutir com eles. Infelizmente, dois ou três alunos apenas tinham visto o filme, então eu tive que contar como que é o enredo e tal, para eles entenderem melhor a sinopse, mas a sinopse foi assim... foi pega de um analista, um crítico de cinema... foi pega, talvez, de uma página da internet. Puseram lá, ipsis literis, em inglês avançado...

Pesquisadora: Aqui você faz que cursos?

G: Aqui faço o curso de Capacitação Profissional.

Pesquisadora: Só?

G: E faço um outro, em uma outra unidade lá.

Pesquisadora: Faz dois cursos?

G: E o curso regular: estou no Fundamental 7. O curso é muito rigoroso em relação à sua proposta e estratégia, mas eu estava realmente enferrujado.

Pesquisadora: Você acha que está sendo muito bom pra você? Em que medida?

G: Está sendo excelente, foi um sonho realizado. Agora dois sonhos: eu não estava esperando fazer um e agora estou fazendo dois... Este aqui é muito diferente, um curso que tem sido muito válido por conta das estratégias, como ensinar Inglês, como ensinar uma LE... Vai ser muito rico... A condução da professora é excelente e o curso regular também. Quase duas horas, duas vezes por semana. Tem 6 alunos na minha classe, quer dizer, você pratica muito, você pratica muito, com esse número reduzido. A professora tem muita técnica, muita didática, é muito organizada, realmente, muito bom, e eu fiquei feliz, porque nas primeiras avaliações, tanto na escrita como na oral, eu tirei exatamente a mesma nota: 86,6.

Pesquisadora: Muito bem! Bem equilibrado....

G: Bem equilibrado! Foi o que ela falou. Ela prefere que seja assim, né? Que seja mais no equilíbrio entre as duas habilitações, nas duas habilidades, do que, às vezes, você tirar uma nota altíssima numa e baixa na outra... Fiquei muito feliz. Está sendo muito proveitoso. Claro, tem que aproveitar, porque é bolsa, né? Então, realmente está sendo muito válido e vai ser muito útil, sem dúvida.

\section{PROFESSOR 1 - MELISSA (M)}

Pesquisadora: Como é possível você dar aula no meio desta bagunça que é a sala de aula?

M: A gente perde uns quinze minutos para aquietar toda a classe, entendeu? Porque tem essa troca de professor. Eu geralmente conto 1, 2, 3, 4... para todo mundo sentar. Fica todo mundo de pé, entendeu? Tudo bem que não é pra ficar... ninguém aguenta ficar dez horas sentado, mas aí, até todo mundo se aquietar... Mas não é assim todo dia, toda aula; tem aula que você consegue dar, tem aula que você não consegue, mas geralmente a indisciplina é praticamente 
geral. Então, você, às vezes, tem que aquietar primeiro para depois... né? Ou você começa a passar coisa na lousa e eles começam a copiar, e aí começam a ficar quietos. Essa é uma das técnicas. Vamos ver. Também já faz 16 anos que eu já dou aula, né? Então eu dava aula no xxx, e quando eu entrei, comecei na prefeitura, eu achei que dava pra ser um diálogo, não sei o que é, mas você tem que ser meio general para funcionar, eu aprendi assim, né? São 30, 35 [alunos na sala]. Eu acho que adolescente também gosta de autoridade, então você tem que ser meio general mesmo, não sempre, mas possivelmente, se você for muito boazinha, você também não consegue dar aula. Que mais? E cada aluno é diferente, você vai com diferentes técnicas, tenta conversar e o aluno não vai por aí. E aí você começa: vou chamar pai, vou chamar mãe, vou escrever bilhete... Se funcionar, é que você agiu certo. Quando eu entrei na prefeitura, realmente, uma coordenadora que era psicóloga falou: "se você agiu desta maneira e funcionou, é porque você agiu certo". Aí eu tenho aplicado assim durante as minhas aulas, na prática mesmo. Daí, se você chama pai e não adianta, você então tenta outro caminho, você tenta falar. Esse R, você lembra? Ficava cantando num sei o quê... Ele tem problema de aprendizagem, não sabe ler e escrever... Não está assim...alfabetizado. Acho que ele é indisciplinado não de agora, isso já vem de anos... Ele já está na sétima. Tem lá uma classe de reforço, mas ele falou que não vai. É, então... Aí, o que acontece? Chamei, na semana passada, o pai dele. Foi chamado e ele foi suspenso por dois dias. Aí... já comecei a agir diferente com ele e falei: "olha, Ronielsom, os outros alunos também querem aprender. Se você se comportar, até o final do ano, eu te dou um presente". Porque foi a única, ai, sei lá.... por enquanto, ele está meio quieto, entendeu? Vamos ver...

Pesquisadora: Mas tem que dar o presente.

M: Ah, sim, aí eu dou o presente para ele!!! (risadas)

Pesquisadora: Você está sendo testada, repetindo o que havia escrito no diário?

M: Ah, sim. Porque eu sou nova nesta escola também, entendeu? Então, eu sinto isso também... Então, eles querem ver até onde você vai, né? "Vamos ver esta professora", porque eles conhecem cada professor. Tem aqueles professores que "você não pode"... e vai até aquele que é "com aquele eu posso tudo". Então, a classe, realmente, eu acho que é outra. Eu sei disso porque, na outra escola em que eu dava aula tinha uma professora de Geografia muito boazinha, sabe? Mas é o [jeito] dela, ela não consegue ser diferente, nunca vai ser. Então, a aula dela era assim: toda a maior bagunça, mas é o jeito dela, ela não consegue mudar, não é? Tem que respeitar a personalidade de cada um, não é? Cada professor tem uma personalidade.

A oralidade, ele consegue, tipo assim: eu trabalho a oralidade. Assim, ele consegue. Muitos que são ruins em outra matéria. Assim, eu pergunto né? Mostro um flashcard: "What is she playing?" - "Ah, soccer!" Isso eles sabem.. Não sei o que... Isso eles sabem... Tem um exercício: falo que é listening comprehension, então eu pergunto e eles tem que responder, em inglês, no caderno, entendeu? Então eu pergunto assim: "What do you like to eat?" Aí, isso ele sabe... Ele sabe se comunicar: pizza. Só que ele não sabe, assim, se você pedir pra ele, talvez, fazer uma composição, ele não vai saber fazer escrita. O problema dele é a escrita. A oralidade, em termos de inglês, você...

Pesquisadora: Você deve trabalhar a oralidade mais que tudo..

M: É, eu acho... um pouquinho de cada coisa, né? Mas eu acho que o que eles gostam muito é da oralidade. Saber falar, entendeu? Isso eles gostam mesmo. Não digo que todos são 
assim. Não são todos que têm esse problema de alfabetização, mas, realmente, tem dois ou três.

Pesquisadora: Tem uma sala especial para aqueles que têm muita dificuldade?

M: Têm! Tem uma sala que eles chamam de "PIC". O que é esse PIC? É o pessoal da quarta série que não passa pra quinta, porque são pré-silábicos. E o que são pré-silábicos? Não conseguem escrever, por exemplo, batata. Se eles escreverem btt, já são alfabéticos. E o que são alfabéticos? Aqueles que já sabem as letras, sabem mais ou menos o som... É por isso que eles passam para a quinta série. Também não é só isso, né? São vários outros problemas... São problemas, assim, de família, né? São vários tipos de problemas, né? Não é só isso também. 


\section{ANEXO 3 - QUESTIONÁRIO APLICADO AOS PROFESSORES}

I ) Você leciona Inglês na rede há:

( ) mais de 5 anos;

( ) menos de 5 anos;

( ) iniciou recentemente;

( ) mais de 10 anos.

II) Você é formado há:

( ) mais de 5 anos;

( ) menos de 5 anos;

( ) mais de 10 anos;

( ) formou-se recentemente.

III) Você teve formação específica para lecionar em classes iniciantes?

( ) $\operatorname{sim}$;

( ) não.

IV) Por que você veio fazer este curso?

V) Como você vê o ensino de Inglês para as classes iniciais do ensino fundamental? 


\section{ANEXO 4 - TERMO DE AUTORIZAÇÃO PARA UTILIZAÇÃO DE INFORMAÇÕES EM PESQUISA CIENTÍFICA}

Universidade de São Paulo

Faculdade de Educação

Programa de Pós-Graduação

\section{Termo de autorização para utilização de informações em pesquisa científica}

É crescente o número de escolas - tanto da rede privada quanto da rede pública de ensino que inserem em seu currículo o ensino de Língua Inglesa, a partir do $1^{\circ}$ ciclo do ensino fundamental. Entretanto, há poucas pesquisas sobre o que motiva essa inserção e como os professores - cuja formação, em princípio, não abrange o ensino para essa faixa etária atribuem sentido ao trabalho que desenvolvem.

Como parte de projeto de Doutorado, estamos coletando dados de diversas fontes para compor um repertório que possibilite analisar, principalmente, questões ligadas ao ensino da Língua Inglesa. Por questões éticas, é fundamental obter a anuência dos informantes, no que toca à utilização dessas informações. É importante afirmar que todas as informações coletadas são confidenciais e serão utilizados números, para garantir aos participantes seu anonimato.

Para autorizar o uso desses trechos de seus escritos ou entrevistas, assine abaixo:

Nome completo:

Assinatura: 


\title{
ANEXO 5 - ENTREVISTA GRAVADA COM ARIADNE NO DIA 30 DE MAIO DE 2008
}

\section{$\mathrm{AE}=$ pesquisadora}

\begin{abstract}
AE: Como pesquisadora, estou tentando identificar a interferência que ocorre, durante o curso, na prática do professor de Inglês da rede. Gostaria que você falasse para mim se observa mudanças no decorrer do seu trababalho e qualquer outra coisa que vier à sua cabeça, relativa especificamente às aulas que você dá.
\end{abstract}

A: Vou começar falando um pouquinho sobre os objetivos do curso.

O nosso maior objetivo é que os professores se tornem professores reflexivos e críticos da sua prática. Este eu acredito que seja o nosso maior objetivo; é claro que para chegar a esse maior objetivo, a gente tem que passar por caminhos primeiro. No início do curso, no primeiro semestre, a gente tem um objetivo menor, que será familiarizar os professores com diferentes métodos e abordagens, teorias de aprendizagem de Língua Inglesa e também tentar fazer com que eles saiam um pouco dessa metodologia, eu diria, tradicional, que é o que a gente percebe que eles mais usam. O grande perfil aqui é esse, desde o início, há dois anos, que estou nesse trabalho com professores da rede estadual; mas eu já estou há oito anos com um projeto com a rede pública e, pelo perfil dos professores, no início, com relação à metodologia e abordagem de como eles ensinam a língua para os alunos, a gente percebe que é através do método tradicional, usando a tradução, certo?

Tendo essa visão da linguagem como um sistema de palavras de signos ou de regras gramaticais, eles acabam ensinando assim e tentando passar isso pros alunos; num primeiro momento, a gente tenta fazer com que eles enxerguem a língua ou o ensino da linguagem de uma outra forma e isso quer dizer que ensinar a língua não é só ensinar regras gramaticais. Então tenta-se mudar um pouquinho essa visão e a gente tenta mostrar as possibilidades de método.

Acaba sendo uma coisa muito rápida, porque o curso tem duração de um ano, mas assim a gente mostra para os alunos-professores as possibilidades de método que a gente tem, e tentase fazer a transição de uma abordagem mais tradicional para uma abordagem menos tradicional, para uma abordagem comunicativa, pensando que esse seria o grande objetivo hoje, das teorias atuais, inclusive dos Parâmetros - os PCNs estão fundamentados nesse princípio da linguagem como comunicação, tendo como meta a comunicação - então a gente tenta passar isso pra eles: como transformar uma aula em que você ensina a língua de uma maneira tradicional - regras, palavras, fazendo a tradução - para uma aula mais comunicativa, mais pro final do curso. E eles vão sempre refletir sobre esses conceitos, desenvolvendo atividades relacionadas aos métodos, fazendo atividades práticas e tentando aplicar atividades em sala de aula.

E, vendo como isso funciona ou não, aí vem a parte da reflexão, que já começa no início do curso. Então a gente sempre pede que eles façam diários e escrevam sobre o que funcionou ou não funcionou, qual a impressão que têm, e assim tenta mudar um pouco essa visão inicial do que é ensinar uma língua estrangeira; visão que a gente percebe que os professores trazem. Partindo pro segundo semestre do curso, então, o objetivo maior é que exista alguma mudança na prática deles. E a gente não tem a pretensão de dizer que vai dar uma receita; o curso não 
tem nada de arbitrário ou prescritivo, dizendo "este é o melhor método", seja relativo à abordagem comunicativa ou a outra abordagem qualquer.

$\mathrm{Na}$ realidade a gente trabalha com a abordagem comunicativa, porque nós acreditamos que ela vá ao encontro das necessidades dos dias de hoje, mais significativas no contexto deles. Mas não tem uma prescrição. A ideia é a de que eles reflitam mesmo sobre a prática e que possam criar as suas próprias, digamos, teorias. Então, no segundo semestre, a gente desenvolve um trabalho de pesquisa-ação.

O que é a pesquisa-ação? Cada professor vai levantar um problema ou algum aspecto que eles (alunos) gostariam de trabalhar mais profundamente e vai selecionar um grupo pra isso, para funcionar como um grupo de pesquisa. Assim, cada professor vai desenvolver um grupo de pesquisa com seus alunos, para que possa aplicar tudo que foi visto no $1^{\mathrm{o}}$ semestre (a questão dos métodos, as abordagens e o desenvolvimento de um trabalho com um foco), a partir do desenvolvimento desse trabalho de pesquisa-ação, relacionada à prática na sala de aula.

Isso vai acontecer com uma turma, para que os professores cheguem às próprias conclusões: vão refletir sobre tudo que acontece e vão descrever cada aula detalhadamente, através de planos de aula. Depois, trarão uma análise e uma reflexão sobre tudo que aconteceu, trazendo pro curso, pras nossas discussões às sextas-feiras, pra que possam compartilhar. Cada um vai ter a sua pesquisa e cada um vai desenvolver a sua pesquisa, dentro da problemática levantada por eles, porque eles têm objetivos diferentes como professores. A gente tem que respeitar a individualidade de cada um e seu contexto, cada um tem seus alunos. Então, a idéia é a de que, através desse trabalho de pesquisa-ação, haja alguma mudança e que haja reflexão contínua, constante, para que eles possam chegar a soluções de problemas. Você me perguntou, no início, se eu notei alguma mudança ou se a gente nota alguma mudança, mas acho que a principal mudança é essa: no início são super-resistentes e tendem a pensar que não existam soluções para os problemas que encontram na sala de aula, no dia a dia da escola pública; enfim acham que é tudo muito complicado muito complexo. E acabam tendo uma postura negativa, uma série de resistências; são bem resistentes no início, inclusive a ideias novas, mas, com o passar do tempo, ficam mais abertos às possibilidades, às novas possibilidades. E acho que a grande mudança que percebo é essa: a mudança na atitude, principalmente de perceber que é possível encontrar soluções para os problemas, tanto os práticos, do cotidiano, da prática da sala de aula, como pra vida mesma deles. Passam a perceber a responsabilidade que têm como professores e pesquisadores, e também, em sala de aula, como podem contribuir para a vida dos alunos, enfim, tornando a aula de Lingua Inglesa mais significativa pra eles. E acho que fica bem clara essa mudança de atitude, de visão com relação à língua.

\section{AE: Bem claro?}

A: Fica muito claro através da leitura dos diários, assim a gente percebe. Até já fiz um trabalho formal em relação a isso; é bem a nítida a mudança de uma postura mais resistente, de um não enfrentamento de problemas a uma visão mais aberta ou à possibilidade de usar diferentes métodos e abordagens, partindo para uma abordagem mais comunicativa, porque esse acaba sendo nosso objetivo também, além de pensar como encontrar soluções pros problemas. É claro que o trabalho que eles desenvolvem com a gente não é uma coisa terminada, não é um produto - "ah, solucionei todos os problemas, agora que fiz o curso, então está tudo bem". Talvez seja o início de um trabalho. Acho que a gente desenvolve aqui exatamente o início de um processo que deve ser continuado na vida deles, na carreira deles; é a vida deles que esta em jogo, eu acho. 
AE: Muda a maneira de eles representarem o mundo deles...

\section{A: Exatamente!}

AE: O que observo é que, quando chegam, (só reclamam de que) é uma indisciplina, porque é uma coisa horrível, porque o aluno é insuportável, que é um problema de droga, porque aquela escola é ao lado da favela... E o que tem a ver isso com a aula? Quer dizer, quando eu fui assitir à aula, vi que ela não tinha nenhum sentido: "pega este papelzinho aqui, escreve em português o que são essas figurinhas..." Nem foi repetida, por exemplo, uma palavra como blouse; eles apenas tinham que olhar e escrever em português; não tinha inglês, não tinha nada

A: Eles nem estavam usando o inglês na aula, é isso?

AE: Nem estavam usando inglês na aula

A: O que eu percebo é que o grande problema é o professor saber exatamente qual é o papel dele. Acho que isso fica muito claro para mim: "o que estou fazendo aqui, qual o meu papel?". Eles não sabem qual o trabalho de professor, qual o trabalho do professor de Língua.

AE: É simplesmente aguentar os alunos e a indisciplina...

A: É a falta de identidade mesmo: não sabem, talvez, o que fazer, então fazem qualquer coisa. É aquilo de tentar solucionar da melhor forma possível.

O que eles trazem muito é que o inglês não faz sentido na vida dos alunos. Isso eles falam: “o inglês não faz sentido; os alunos não têm interesse; não sabem nem falar português, porque teriam interesse na aula de inglês?" Eu acho que é isso. É buscar uma maneira de, primeiro, fazer com que esses professores entendam que o inglês pode fazer parte do contexto do aluno, de uma maneira significativa. Primeiro, o professor tem que entender isso, pra que depois, comprando essa idéia ou, pelo menos, se tornando consciente disso, de que isso é possível, aí sim procurar maneiras práticas de fazer isso. É no que a gente tem que ajudar, passar estratégias, atividades, maneiras de usar o inglês de modo mais significativo, e que eles transformem isso dentro da realidade deles, através de toda parte prática e teórica que a gente vê, no curso, cada um aplicar

No começo, achei que tivesse uma relação, por exemplo, entre nível linguísitico e nível metodológico, mas depois acabei percebendo que não. Ou, pelo menos, nível linguístico e nível de resistência, que é um trabalho ao qual eu quero até dar continuidade, porque, por exemplo, os professores que têm maior conhecimento de língua acham que isso basta? Ou têm uma postura mais aberta com relação à metodologia? $\mathrm{O}$ fato de o nível de conhecimento de língua ser mais alto traz mais facilidade ou faz absorver mais?

AE: Eu acho que é uma premissa que corre inconscientemente e é atribuída, por exemplo, ao native speaker: mesmo que a gente aqui seja professora, é native speaker, então, pronto, não precisa de mais nada. Você já não percebeu isso? Existe esse mito: "Ah, ele é native."

A: Ele já tem a língua. O que não é verdade, né? Porque, pra você ter uma ideia, eu já tive trabalhos maravilhosos feitos por professores cujo nível linguístico era básico, bem básico. Eles faziam o nível 1 aqui, mas o pouco que eles explicavam tinha sentido. Conseguiam preparar aulas maravilhosas, atendendo às necessidades dos alunos e até aplicando uma 
abordagem mais comunicativa. E com aquele pouco conhecimento que tem da língua. Tem isso: eu acho que é um mérito de nosso curso, acontece muito durante o curso.

A aula de Língua acaba sendo uma prática para esses professores, um modelo pra eles seguirem. A gente trabalha em conjunto com os professores e eles assistem à aula. Então, na medida do possível, a gente sempre tenta fazer um trabalho assim bem conjunto mesmo, mas às vezes funciona mais, às vezes, menos; mas, por exemplo, se eles estão vendo habilidade de leitura, na aula de Metodologia, a gente tenta falar com o professor de Língua, para que procure dar atividades de leitura que sirva como follow up, ou como modelo, enfim que eles possam ver isso na prática. A gente, então, procura fazer essa interação, e nem sempre acontece na prática; a gente sabe que é difícil, mas tenta fazer isso 